\title{
REVIEW
}

\section{Chemical interactions between marine macroalgae and bacteria}

\author{
Franz Goecke, Antje Labes, Jutta Wiese, Johannes F. Imhoff* \\ Kieler Wirkstoff-Zentrum at the Leibniz Institute of Marine Sciences (IFM-GEOMAR), Am Kiel-Kanal 44, Kiel 24106, Germany
}

\begin{abstract}
We review research from the last $40 \mathrm{yr}$ on macroalgal-bacterial interactions. Marine macroalgae have been challenged throughout their evolution by microorganisms and have developed in a world of microbes. Therefore, it is not surprising that a complex array of interactions has evolved between macroalgae and bacteria which basically depends on chemical interactions of various kinds. Bacteria specifically associate with particular macroalgal species and even to certain parts of the algal body. Although the mechanisms of this specificity have not yet been fully elucidated, ecological functions have been demonstrated for some of the associations. Though some of the chemical response mechanisms can be clearly attributed to either the alga or to its epibiont, in many cases the producers as well as the mechanisms triggering the biosynthesis of the biologically active compounds remain ambiguous. Positive macroalgal-bacterial interactions include phytohormone production, morphogenesis of macroalgae triggered by bacterial products, specific antibiotic activities affecting epibionts and elicitation of oxidative burst mechanisms. Some bacteria are able to prevent biofouling or pathogen invasion, or extend the defense mechanisms of the macroalgae itself. Deleterious macroalgal-bacterial interactions induce or generate algal diseases. To inhibit settlement, growth and biofilm formation by bacteria, macroalgae influence bacterial metabolism and quorum sensing, and produce antibiotic compounds. There is a strong need to investigate the bacterial communities living on different coexisting macroalgae using new technologies, but also to investigate the production, localization and secretion of the biological active metabolites involved in those possible ecological interactions.
\end{abstract}

KEY WORDS: Marine microoganisms - Defense - Beneficial communication - Biofilms · Oxidative burst $\cdot$ Antibiotic activity $\cdot$ Quorum sensing control

\section{INTRODUCTION}

Over the past decades an intensive collaboration between chemists and ecologists has resulted in an increasing number of studies which have combined modern chemical techniques with ecologically relevant experiments and theories (Pawlik 2000, Hay 2009). Thousands of marine secondary metabolites have been identified (Hay 1996). These compounds have been shown to play a major role in mediation of diverse ecological interactions (Dworjanyn et al. 1999). Chemical ecology has provided significant insights into the ecology, evolution and organization of marine populations, communities, and also into the function of marine ecosystems (Hay 2009). Selected aspects of marine chemical ecology have been frequently reviewed with a focus on specific taxonomic groups or systems (see Hay 2009 and references therein). Thus, the establishment and composition of communities on surfaces and on bodies of organisms (epibiosis, biofouling) and the processes involved have been described by several authors (Wahl 1989, 2008, Krug et al. 2006, Qian et al. 2007, Harder 2009, Hay 2009). Sessile invertebrates such as tunicates, cnidarians, bryozoans, barnacles, and sponges were the model systems for these experiments. With respect to the chemical ecology of algae, investigations were focused either on the capabilities of the macroalgae for chemical defense against grazers or 
on the communication between algae, e.g. for reproductive purposes (see Cronin \& Hay 1996, Paul \& Puglisi 2004, Amsler 2008 and references therein, Macaya \& Thiel 2008, Paul \& Ritson-Williams 2008). A few interesting studies have been presented on fungi, microalgae and protozoa as associates of macroalgae (see Harder 1999, Hellio et al. 2002, Raghukumar 2002, Kohlmeyer \& Volkmann-Kohlmeyer 2003, Lam et al. 2008b). Detailed knowledge of the interaction of algae with their associated microbes and among microbes on algal surfaces and tissues is still lacking (Steinberg et al. 1997, Steinberg \& de Nys 2002, Kubanek et al. 2003). Therefore, this review will focus on specific interactions between macroalgae and bacteria.

\section{COLONIZATION OF MACROALGAL SURFACES BY MARINE MICROBES}

\section{Microbial epibiosis}

Microorganisms are an essential component of earth's biosphere (Whitman et al. 1998). Their number in aquatic environments is enormous. Seawater contains up to $10^{7}$ viruses, $10^{6}$ bacteria, $10^{3}$ fungi, $10^{3}$ microalgae, and 10 to 100 microscopic larvae and spores per ml (Cole 1982, Jensen \& Fenical 1994, Engel et al. 2002, Harder 2009). The aquatic environment favors the development of microbes and the formation of biofilms on surfaces (Weinberger 2007). Macroalgae are especially susceptible to epibiosis because they live in an environment with strong competition for space amongst benthic organisms (Hellio et al. 2001, Harder et al. 2004, Potin et al. 2002, Lam et al. 2008b). In addition, algal surfaces provide a habitat rich in organic material. Macroalgae release large amounts of organic carbon into the surrounding environment, providing nutrients for microorganisms (Khailov \& Burlakova 1969, Kong \& Chan 1979, Bouvy et al. 1986, Armstrong et al. 2001, Lane \& Kubanek 2008) and triggering chemotactic behaviour of bacteria (Bell \& Mitchell 1972, Paul \& Puglisi 2004). Most primary metabolites such as carbohydrates, amino acids, peptides, and proteins are inducers of microbial colonization (Steinberg et al. 2002). Hence, the surface of a macroalga provides a protected microniche favorable for bacterial colonization and reproduction (Byappanahalli et al. 2003, Beleneva \& Zhukova 2006, Mahmud et al. 2007, Englebert et al. 2008). For this reason, marine macroalgae are continuously challenged by microorganisms as well as by grazers (Weinberger et al. 1997, Bouarab et al. 2001).

The resulting marine microbial communities covering macroalga are complex and highly dynamic ecosystems, consisting of a diverse range of organisms
(Holmström et al. 2002, Honkanen \& Jormalainen 2005, Krug et al. 2006). Bacteria are dominant among the primary colonizers of algal surfaces, followed by diatoms and fungi (Qian et al. 2007, Lam et al. 2008a).

While some macroalgae are heavily colonized, other algal species in the same habitat remain almost free of epibionts. Such differences may even be found in closely related species living in the same habitat, e.g. in Fucus evanescens which show little epibiosis and $F$. vesiculosus which are heavily fouled (Wikström \& Pavia 2004). This indicates the presence of an established antifouling defense in only some macroalgal species (de Nys et al. 1993, Steinberg \& de Nys 2002, Bhadury \& Wright 2004, Nylund \& Pavia 2005) and, on the other hand, species-specific contact mechanisms between algae and bacteria.

\section{Bacterial communities associated with macroalgae}

Descriptive studies of bacteria isolated from the surface of macroalgae were reported as early as 1875 (Johansen et al. 1999). The interest in bacterial populations living in association with macroalgae has increased during recent decades. We found 107 studies on bacterial communities associated to a total of 148 macroalgae (36 Chlorophyta, 46 Phaeophyceae, 55 Rhodophyta, 12 undetermined algae) within the last 40 yr (Table 1 \& Appendix 1). Bacterial-macroalgal associations were shown to be widely distributed in marine habitats (Appendix 1). The number and complexity of these studies increased significantly during the past decade. This increase can be attributed to the combined use of improved methods in bacterial culture, microscopy and molecular biology (Fig. 1). However, many questions concerning the occurrence, distribution, persistence and ecological function of the associated bacteria remain unresolved.

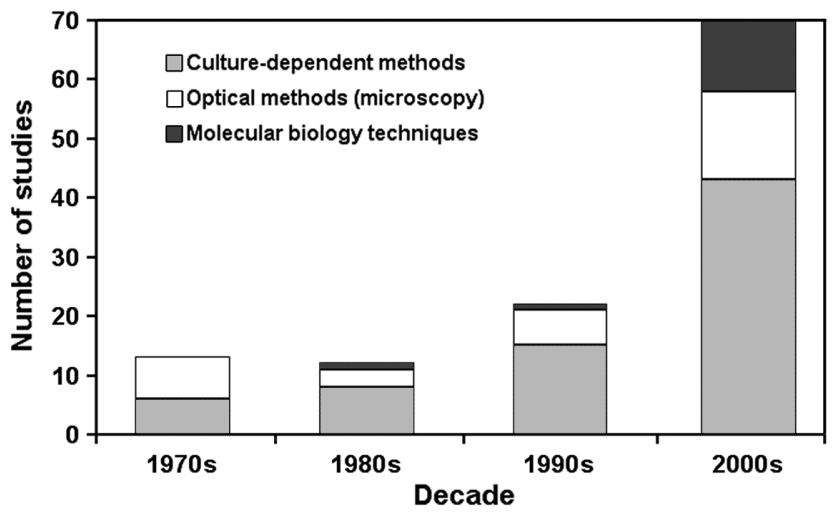

Fig. 1. Worldwide studies of bacterial communities associated with macroalgae in the last 4 decades, showing the methodology used for the analysis. Data refers to Table 1 \& Appendix 1 
Table 1. Macroalgae as source of new bacterial species. Quotation marks indicate proposed but not yet validated species

\begin{tabular}{|c|c|c|}
\hline Macroalga & Bacterial species & Source \\
\hline \multicolumn{3}{|l|}{ Chlorophyta } \\
\hline \multirow[t]{6}{*}{ Acrosiphonia sonderi (Kütz.) Kornm. } & Algibacter lectus & Nedashkovskaya et al. (2004e) \\
\hline & Formosa agariphila & Nedashkovskaya et al. (2006a) \\
\hline & Mesonia algae & Nedashkovskaya et al. (2003) \\
\hline & Pibocella ponti & Nedashkovskaya et al. (2005a) \\
\hline & Winogradskyella epiphytica & Nedashkovskaya et al. (2005c) \\
\hline & Zobellia russellii & Nedashkovskaya et al. (2004b) \\
\hline Avrainvillea riukiuensis Yamada & Tenacibaculum amylolyticum & Suzuki et al. (2001b) \\
\hline Capsosiphon fulvescens (Agardh) Setchell \& Gardner & Aequorivita capsosiphonis & Park et al. (2009) \\
\hline Caulerpa sp. & Microbulbifer epialgicus & Nishijima et al. (2009) \\
\hline Enteromorpha linza (L.) J. Agardh & Erythrobacter longus & Shiba \& Simidu (1982) \\
\hline \multirow[t]{7}{*}{ Ulva fenestrata Ruprecht } & Algibacter lectus & Nedashkovskaya et al. (2004e) \\
\hline & Arenibacter certesii & Nedashkovskaya et al. (2004a) \\
\hline & Arenibacter palladensis & Nedashkovskaya et al. (2006b) \\
\hline & Maribacter ulvicola & Nedashkovskaya et al. (2004d) \\
\hline & Pseudozobellia thermophila & Nedashkovskaya et al. (2009) \\
\hline & Roseivirga ehrenbergii & Nedashkovskaya et al. (2005b) \\
\hline & Ulvibacter litoralis & Nedashkovskaya et al. (2004c) \\
\hline Ulva lactuca L. & Pseudoalteromonas ulvae & Egan et al. (2001a) \\
\hline \multicolumn{3}{|l|}{ Heterokontophyta, Phaeophyceae } \\
\hline \multirow[t]{2}{*}{ Chorda filum (L.) Stackhouse } & Arenibacter latericius & Ivanova et al. (2001) \\
\hline & Winogradskyella thalassocola & Nedashkovskaya et al. (2005c) \\
\hline \multirow[t]{3}{*}{ Ecklonia kurome Okamura } & Croceitalea dokdonensis & Lee et al. (2008b) \\
\hline & Croceitalea eckloniae & Lee et al. (2008b) \\
\hline & Flagellimonas eckloniae & Bae et al. (2007) \\
\hline \multirow[t]{4}{*}{ Fucus evanescens C. Agardh } & Bacillus algicola & Ivanova et al. (2004a) \\
\hline & Brevibacterium celere & Ivanova et al. (2004b) \\
\hline & Formosa algae & Ivanova et al. (2004c) \\
\hline & Pseudoalteromonas issachenkonii & Ivanova et al. (2002b) \\
\hline \multirow[t]{2}{*}{ Fucus serratus L. } & Cellulophaga baltica & Johansen et al. (1999) \\
\hline & Cellulophaga fucicola & Johansen et al. (1999) \\
\hline Kjellmaniella crassifolia Miyabe & 'Fucobacter marina' & Sakai et al. (2002) \\
\hline \multirow[t]{3}{*}{ Laminaria japonica Areschoug } & Pseudoalteromonas bacteriolytica & Sawabe et al. (1998b) \\
\hline & Winogradskyella eximia & Nedashkovskaya et al. (2005c) \\
\hline & Zobellia laminariae & Nedashkovskaya et al. (2004b) \\
\hline Lessonia sp. & Alteromonas atlantica & Akagawa-Matsushita et al. (1992) \\
\hline Padina sp. & Roseibacillus ponti & Yoon et al. (2008) \\
\hline Pocockiella sp. & Microbulbifer variabilis & Nishijima et al. (2009) \\
\hline Saccharina latissima (L.) Lane et al. & Kiloniella laminariae & Wiese et al. (2009a) \\
\hline Undaria pinnatifida (Harvey) Suringar & ‘Gracilibacillus sp.' & Tang et al. (2009) \\
\hline \multicolumn{3}{|l|}{ Rhodophyta } \\
\hline Delesseria sanguinea (Huds.) Lamour & Zobellia galactanovorans & Barbeyron et al. (2001) \\
\hline \multirow[t]{2}{*}{ Gigartinaceae } & Lacinutrix algicola & Nedashkovskaya et al. (2008) \\
\hline & Lacinutrix mariniflava & Nedashkovskaya et al. (2008) \\
\hline Jania sp. & Shewanella alga & Simidu et al. (1990) \\
\hline Polysiphonia japonica Harvey & Maribacter polysiphoniae & Nedashkovskaya et al. (2007) \\
\hline Porphyra sp. & 'Phycisphaera mikurensis' & Fukunaga et al. (2009) \\
\hline Unidentified red algae & Luteolibacter algae & Yoon et al. (2008) \\
\hline \multicolumn{3}{|l|}{ Unidentified macroalgae } \\
\hline & Aeromicrobium tamlense & Lee \& Kim (2007) \\
\hline & Agarivorans gilvus & Du et al. (in press) \\
\hline & Agrococcus jejuensis & Lee (2008) \\
\hline & Ferrimonas marina & Katsuta et al. (2005) \\
\hline & Flavobacterium algicola & Miyashita et al. (2010) \\
\hline & Koreibacter algae & Lee \& Lee (in press) \\
\hline & Labedella gwakjiensis & Lee $(2007)$ \\
\hline & Mesonia phycicola & Kang \& Lee (2010) \\
\hline & Nitratireductor kimnyeongensis & Kang et al. (2009) \\
\hline & Paracoccus zeaxanthinifaciens & Berry et al. (2003) \\
\hline & Phycicoccus jejuensis & Lee $(2006)$ \\
\hline & Phycicola gilvus & Lee et al. (2008a) \\
\hline
\end{tabular}


Phylogenetic studies of epiphytic bacteria provided an insight into the complex bacterial communities associated with macroalgae (Penesyan et al. 2009). Bacterial communities living on marine macroalgae differ in number and composition of species from those occurring in seawater (Kong \& Chan 1979, Lemos et al. 1985, Mow-Robinson \& Rheinheimer 1985, Johnson et al. 1991, Steinberg et al. 2002, Longford et al. 2007). In most cases, the epiphytic bacterial communities are highly specific. Some microbes are found consistently as epiphytes, e.g. Leucothrix mucor (Bland \& Brock 1973). Recently, the variability and abundance of the epiphytic bacterial community associated with Ulva australis was investigated using molecular methods. The results showed that members of the Alphaproteobacteria and the Bacteroidetes were a stable part of the associated bacterial population (Tujula et al. 2010). Bacterial-macroalgal associations comprised a number of new bacterial species, genera and even orders, proving that macroalgae represent a distinct and rich source of new microbial taxa (Genilloud et al. 1994). From 36 macroalgal species, 56 new bacterial species have been isolated (32\% from Chlorophyta, 35\% from Phaeophyceae, $12 \%$ from Rhodophyta, and $21 \%$ from undetermined algae) (Table 1).

Considering all available evidence, including our own observations (Staufenberger et al. 2008, Lachnit et al. 2009, Wiese et al. 2009a,b), it is reasonable to conclude that a highly specific association of bacterial communities with marine macroalgae exists. It has been proposed that the physiological and biochemical properties of macroalgae predetermine the composition of the adhering microbial communities (Beleneva \& Zhukova 2006). Different species of marine algae growing under the same environmental conditions bear different bacterial communities, varying in number and composition. This assumption was investigated, using a molecular approach, by Lachnit et al. (2009) regarding the bacterial populations on Delesseria sanguinea, Fucus vesiculosus, Saccharina latissima (formerly Laminaria saccharina), and Ulva compressa growing in 2 different habitats. In that study, it was demonstrated that bacterial communities derived from macroalgae belonging to the same species but originating from a different habitat were more similar than those from different species inhabitating the same ecological niche. Similar results were obtained by Nylund et al. (2010), who analyzed 2 localities on the west coast of Sweden with respect to the bacteria associated with the red macroalgal species Bonnemaisonia asparagoides, Lomentaria clavellosa and Polysiphonia stricta.

In general, a stable association between host and microorganisms is observed (Kong \& Chan 1979, Shiba \& Taga 1980, Lewis et al. 1985, Johnson et al. 1991); however, over the seasons or over the life span of the basibiont the composition of the bacterial communities may change (Laycock 1974, Hornsey \& Hide 1976a, Sakami 1996, Staufenberger et al. 2008). This has been demonstrated for bacteria associated with Ascophyllum nodosum, Fucus vesiculosus, Sargassum natans and Ulva australis (Sieburth \& Conover 1965, Sieburth \& Tootle 1981, Hellio et al. 2004, Tujula et al. 2010). Furthermore, it was reported that the composition of the bacterial communities varies on different parts of the thallus, e.g. for Ascophyllum nodosum (Cundell et al. 1977), Chara vulgaris (Ariosa et al. 2004), and Saccharina latissima (Staufenberger et al. 2008) (Fig. 2). In addition to different structural features of the specific parts of the algal thallus, these differences may be explained by a lack of vascular connections in the algal tissue and by the resulting deficit in efficient resource translocation (Honkanen \& Jormalainen 2005). Various biological activities (for example antibacterial and antiherbivory activities) were found in extracts from different parts of macroalgae which was shown by unequal concentrations of the different secondary metabolites throughout the thallus (Hornsey \& Hide 1976b, Meyer \& Paul 1992, Vlachos et al. 1999, FreilePelegrin \& Morales 2004, Macaya et al. 2005). This effect was shown for a number of metabolites, such as soluble phlorotannins and halogenated organic compounds (Mehrtens \& Laturnus 1997, Koivikko et al. 2005). In the brown alga Dictyota ciliolata, for example, the secondary metabolites pachydictyol A, dictyol $B$ acetate, dictyodial, and sterols were shown to be present in higher concentrations in older, less palatable tissues than in apical meristem (Cronin \& Hay 1996). The same phenomenon was observed in the red macroalga Neorhodomela larix regarding its content of bromophenols such as lanosol (Phillips \& Towers 1982, Carlson et al. 1989). Therefore, different allocation and concentration of the chemical compounds may lead to different microbial communities at the different parts of macroalgae (Fig. 2).

Although some of the bacterial-algal interactions have been discussed earlier, the ecological relevance of most naturally occurring bacterial communities on macroalgae remains unclear and in most cases the bacterial species involved have not yet been identified (Duan et al. 1995, Ivanova et al. 2002a). For example, many coenocytic green macroalgae such as Caulerpa, Codium, Bryopsis and Penicillus spp. have been shown to harbour endosymbiotic bacteria, as shown by microscopic studies (Burr \& West 1970, Turner \& Friedmann 1974, Dawes \& Lohr 1978, Rosenberg \& Paerl 1981). However, only in Caulerpa taxifolia could it be shown, using molecular approaches, that Herbaspirillum sp.related bacteria are host-specific endosymbionts (Meusnier et al. 2001, Delbridge et al. 2004). The characterization of microorganisms associated with algae is 
still at an early stage of development and detailed molecular studies on microbial communities associated with macroalgae are rare (Staufenberger et al. 2008). Studies of macroalgal-microbial interactions have lagged, mainly for methodological reasons (Largo et al. 1997, Kohlmeyer \& Volkmann-Kohlmeyer 2003). Suitable tools for the analysis of epiphytic bacterial communities including culture-independent approaches were not available until molecular techniques were introduced to this field of research (Fig. 1) (Ashen \& Goff 1998, 2000, Meusnier et al. 2001, Ohkubo et al. 2006, Tujula et al. 2006, Weinberger 2007, Burke et al. 2009). Until now, most of the available information about bacterial-macroalgal interactions was obtained from culture studies (Fisher et al. 1998, Skovhus et al. 2004). If we consider that only ca. 1 to $10 \%$ of the associated bacteria have been cultivated (Jensen et al. 1996), it is reasonable to assume that most of the ecologically relevant bacteria are not known so far. The same is true for their possible susceptibility to naturally released algal metabolites (Paul et al. 2006). However, an increasing number of results demonstrate that chemical interactions determine the bacterial-algal relationships. The substances on the surface of a macroalga include exuded secondary metabolites and extracellular exopolymers. As soon as algal metabolites are degraded by the associated bacteria, the chemical cocktail may be further enriched (Lachnit et al. 2010). Many bacterial taxa obtained from algal tissue are able to degrade sugars produced by algae, such as alginate, cellulose and manitol (Table 2). They are considered to be involved in the decay process of algal fronds (Johnson et al. 1971, Lewis et al. 1985, Uchida \& Nakayama 1993, Jensen et al. 1996, Sakami 1999, Ivanova et al. 2005). Probably, this is one reason for specific macroalgal-bacterial interactions (Kong \& Chan 1979, Lu et al. 2008).

Numerous studies on antifouling activity of extracts and isolated substances from macroalgae have shown that algae are a rich source of bioactive compounds

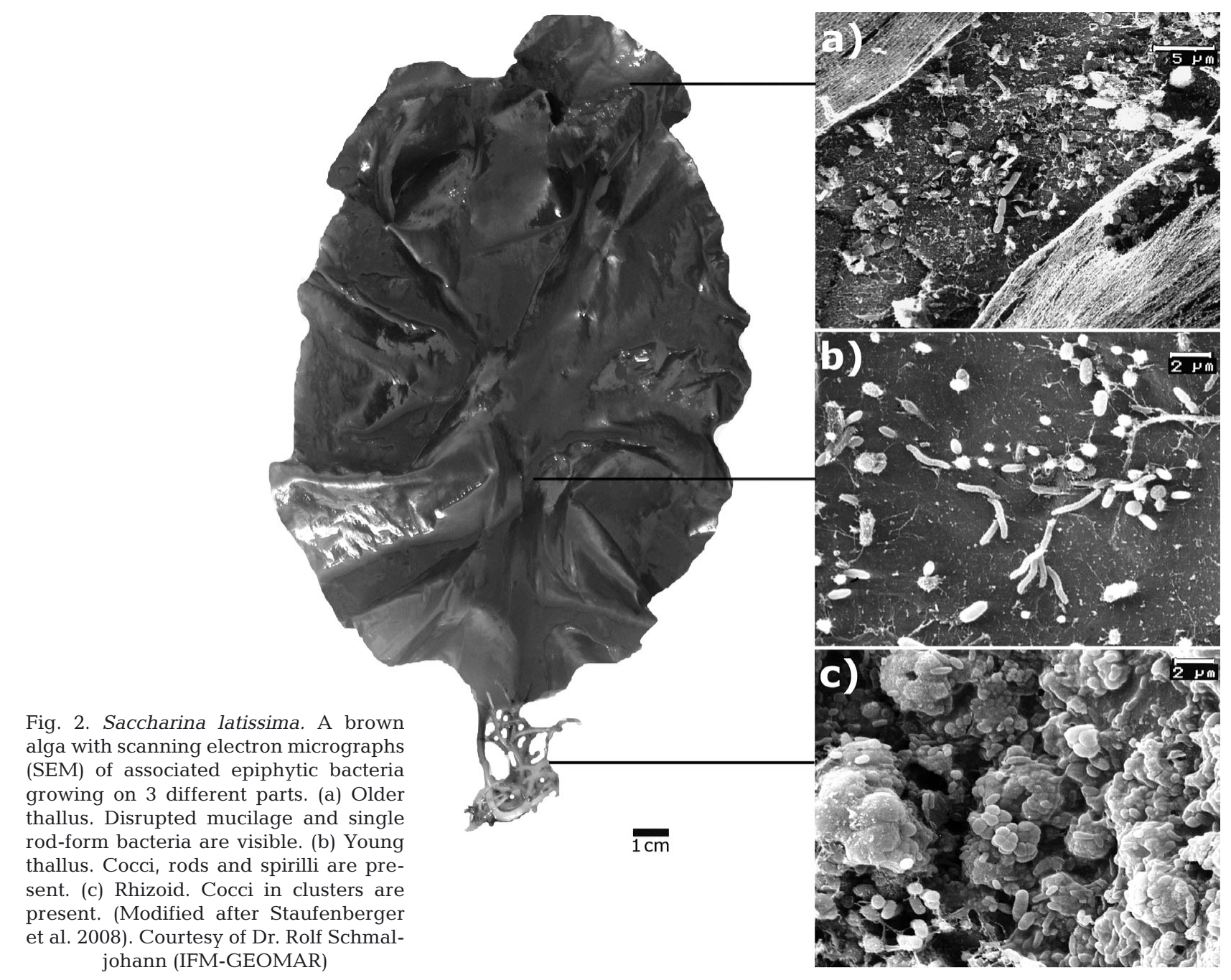


Table 2. Enzymatic activities detected in marine bacteria that are relevant to the degradation of macroalgal cell walls. ${ }^{*}$ Bacteria isolated from algae

\begin{tabular}{|c|c|c|}
\hline Enzyme & Bacteria & Source \\
\hline Agarases & $\begin{array}{l}\text { Acinetobacter sp. } \\
\text { Agarivorans spp. } \\
\text { Alterococcus spp. } \\
\text { Alteromonas spp.* } \\
\text { Bacillus sp. } \\
\text { Cellulophaga baltica* }{ }^{*} \text { C. fucicola* } \\
\text { Cytophaga spp. } \\
\text { Flavobacterium spp } \\
\text { Glaciecola agarilytica } \\
\text { Marinilabilia spp. } \\
\text { Microbulbifer spp.* } \\
\text { Microscilla spp. } \\
\text { Phycisphaera mikurensis* } \\
\text { Pseudoalteromonas agarivorans* } \\
\text { P. antarctica*, P. gracilis* } \\
\text { Pseudomonas atlantica* } \\
\text { Persicobacter spp. } \\
\text { Pseudozobellia thermophila* } \\
\text { Saccharophagus spp. } \\
\text { Thalassomonas spp. } \\
\text { Vibrio spp. } \\
\text { Zobellia galactanovorans }^{*}, \text { Z. laminariae }^{*}, \text { Z. russellii* }^{*}\end{array}$ & $\begin{array}{l}\text { Yaphe (1957), Quatrano \& Caldwell (1978), Vera } \\
\text { et al. (1998), Allouch et al. (2003), Johansen et al. } \\
\text { (1999), Romanenko et al. (2003), Schroeder et al. } \\
\text { (2003), Nedashkovskaya et al. (2004b), Jam et al. } \\
\text { (2005), Michel et al. (2006), and literature therein } \\
\text { Flament et al. (2007), Yong et al. (2007), Fuku- } \\
\text { naga et al. (2009), Nedashkovskaya et al. (2009), } \\
\text { Fu \& Kim (2010) }\end{array}$ \\
\hline Carrageenases & $\begin{array}{l}\text { Alteromonas fortis } \\
\left.\text { Cytophaga (Cytophaga drobachiensis }{ }^{*}\right) \\
\text { Marinilabilia spp. } \\
\text { Microbulbifer sp. }{ }^{*} \text { CMC-5 } \\
\text { Microbulbifer elongates } \\
\text { Pseudoalteromonas carrageenovora* } \\
\text { Zobellia galactanivorans** }\end{array}$ & $\begin{array}{l}\text { Yaphe \& Baxter (1955), Sarwar et al. (1983), Potin } \\
\text { et al. (1991), Nakagawa \& Yamasato (1996), } \\
\text { Barbeyron et al. (1998, 2000), Michel et al. (2006), } \\
\text { and literature therein, Jam et al. (2005), Khamb- } \\
\text { haty et al. (2007), Jonnadula et al. (2009) }\end{array}$ \\
\hline Alginases & $\begin{array}{l}\text { Alcaligenes spp. }{ }^{*} \\
\text { Alginomonas spp. } \\
\text { Alginovibrio }(\text { A. aquatilis) } \\
\text { Alteromonas atlantica*, A. carrageenovora* }{ }^{*} \text { A. sp. }{ }^{*} \\
\text { Cytophaga diffluens } \\
\text { Deleya marina* } \\
\text { Flavobacterium sp. }{ }^{*} \\
\text { Glaciecola sp. } \\
\text { Gracilibacillus spp.* G halotolerans* } \\
\text { Halomonas marina, H. sp. AW4* } \\
\text { Moraxella sp.* } \\
\text { Ochrobactrum sp.* } \\
\text { Pseudoalteromonas sp.* } \\
\text { Pseudomonas alginovora* } \\
\text { Streptomyces sp. ALG-5* } \\
\text { Vibrio spp. (V. fischeri* }, \text { V. harveyi* })\end{array}$ & $\begin{array}{l}\text { Ando \& Inoue (1961), Davidson et al. (1976), } \\
\text { Stevens \& Levin (1977), Quatrano \& Caldwell } \\
\text { (1978) and references therein, Preston et al. } \\
\text { (1986), Boyen et al. (1990), Brown et al. (1991), } \\
\text { Tseng et al. (1991), Akagawa-Matsushita et al. } \\
\text { (1992), Ramaiah \& Chandramohan (1992), } \\
\text { Sawabe et al. (1992), Uchida \& Nakayama (1993), } \\
\text { Uchida et al. (1995), Sakami (1999), Sawabe et al. } \\
\text { (1997, 1998a), Kraiwattanapong et al. (1999), } \\
\text { Ivanova et al. (2002a,b), Uchida et al. (2002), } \\
\text { Wang et al. (2006), Sawabe et al. (2007), An et al. } \\
\text { (2008, 2009), Tang et al. (2008), Zhou et al. } \\
\text { (2008), Kim et al. (2009), Tang et al. (2009) }\end{array}$ \\
\hline Fucoidanases & $\begin{array}{l}\text { Arenibacter spp. }{ }^{*} \\
\text { Flavobacterium algicola* } \\
\text { Fucobacter marina* } \\
\text { Fucophilus fucoidanolyticus* } \\
\text { Gramella sp. } \\
\text { Maribacter sp. } \\
\text { Mesonia algae } \\
\text { Pseudoalteromonas citrea* } \\
\text { P. issachenkonii* } \\
\text { Sphingomonas paucimobilis } \\
\text { Vibrio sp. } \\
\text { Zobellia sp. }\end{array}$ & $\begin{array}{l}\text { Furukawa et al. (1992), Bakunina et al. (2000, } \\
\text { 2002), Ivanova et al. (2002a), Sakai et al. (2002, } \\
\text { 2003, 2004), Kusaykin et al. (2006), Urvantseva et } \\
\text { al. (2006), Kim et al. (2008), Miyashita et al. 2010) }\end{array}$ \\
\hline Fucanases & $\begin{array}{l}\text { Alteromonas sp. SN-1009 } \\
\text { Mariniflexile fucanivorans }\end{array}$ & $\begin{array}{l}\text { Colin et al. (2006), Descamps et al. (2006), } \\
\text { Barbeyron et al. (2008) }\end{array}$ \\
\hline Mannanase & $\begin{array}{l}\text { Aeromonas sp. F-25 } \\
\text { Bacillus subtilis } \\
\text { Pseudomonas sp. PT-5* } \\
\text { Streptomyces lividans } \\
\text { Vibrio } \text { sp. }^{*}\end{array}$ & $\begin{array}{l}\text { Yamaura et al. (1990), Moreira \& Filho (2008), } \\
\text { Tanaka et al. (2009) }\end{array}$ \\
\hline $\begin{array}{l}\text { Cellulases } \\
\& \text { pectinases }\end{array}$ & $\begin{array}{l}\text { Acinetobacter spp. } \\
\text { Alteromonas spp. } \\
\text { Flavobacterium spp. } \\
\text { Pseudoalteromonas sp. }{ }^{*} \\
\text { Vibrio spp. }{ }^{*}\end{array}$ & $\begin{array}{l}\text { Araki et al. (1992), Ramaiah \& Chandramohan } \\
\text { (1992), Yamasaki et al. (1998), Ivanova et al. } \\
\text { (2002a), Yoshimura et al. (2006) }\end{array}$ \\
\hline
\end{tabular}


against colonizing organisms (see section below on antibiotic activities of macroalga-associated bacteria and Table 5) (Steinberg et al. 1998, Bhadury \& Wright 2004, Dobretsov et al. 2006b, Lane \& Kubanek 2008, and references therein, Nylund et al. 2008). In addition to being defense mechanisms, these substances can trigger specific interactions between macroalgae and colonizers. Macroalgae without their own chemical defense are considered to rely on the secondary metabolites produced by their associated bacteria (Holmström et al. 1992, Egan et al. 2000 and references therein). Dobretsov \& Qian (2002) showed that the antifouling mechanisms of Ulva reticulata (Chlorophyta) rely not only on compounds released from the alga itself but also on those produced by epibiotic bacteria, e.g. by a thallus-associated Vibrio sp. (Harder et al. 2004).

Fouling organisms have negative effects on host growth and reproduction. Hence, evolutionary pressure on marine macroalgae has favored the development of mechanisms to defend their surfaces against biofilms (Wahl 1989, Steinberg \& de Nys 2002).

\section{DETRIMENTAL BACTERIAL-MACROALGAL INTERACTIONS - DISEASES}

Quantification of bacterial epiphytes on different marine macrophytes showed that healthy individuals carry $10^{4}$ to $7 \times 10^{5}$ bacteria per gram algal fresh weight (Laycock 1974, Jensen et al. 1996). By contrast, the number of bacteria and saprophytes was increased by more than 2 orders of magnitude (440 times) in diseased macroalgae (Weinberger et al. 1994). Despite some beneficial aspects of epibiosis (see Wahl 1989, 2008), biofilm formation produces a permanent threat to macroalgae (Steinberg et al. 1997, Potin et al. 2002, Honkanen \& Jormalainen 2005, Nylund \& Pavia 2005, Medeiros et al. 2007). Epibiosis may lead to increased hydrodynamic drag on the basibiont. It may reduce the buoyancy and elasticity of the tissue, attract grazers, and thereby increase tissue loss of the host or may even result in its destruction. In additon, bacteria compete with algae for nutrients and may even be more efficient in uptake and assimilation of nutrients (Berland et al. 1972). Biofilms may also inhibit gaseous exchange as well as reducing incident light and thereby decrease photosynthetic activity (Provasoli \& Pintner 1980, Sieburth \& Tootle 1981, Wahl 1989, 2008, Steinberg et al. 1997, Mindl et al. 2005). Bacterial biofilms may enhance the attachment and growth of a range of other fouling organisms, such as diatoms, invertebrate larvae, and algal spores (Joint et al. 2002, Tait et al. 2005, Huggett et al. 2006). The host may even be damaged directly by the bacterial community due to the production of toxins, digestive enzymes, inhibitors or waste products (Weinberger et al. 1997, Ivanova et al. 2002a,b, Patel et al. 2003, Rao et al. 2006) (Table 2).

Microorganisms that are common on the surface of macroalgae might become detrimental if they are able to enter the algal tissue. In order to attack the frond tissues, a pathogen must penetrate the cuticle layers of the macroalga (Craigie et al. 1992). Algal cell walls and cuticles contain a great diversity of polysaccharides, which make them chemically and structurally more complex and heterogeneous than those of terrestrial plants (Polne-Fuller \& Gibor 1987). Bacteria capable of degrading the macroalgal cell wall are important factors for the damage of algal tissue and provide an entrance for pathogenic and opportunistic bacteria (Buschmann et al. 1997, Ivanova et al. 2005). Not only bacteria but also algal endophytes are able to breach the cuticula and cell wall and facilitate secondary infections. An example of this is the green endophytic alga Acrochaete operculata. It causes cellular damage to Chondrus crispus (Rhodophyta) and leads to secondary bacterial infections by facultative pathogens from the Cytophaga/Flavobacterium group (Correa \& McLachlan 1994, Craigie \& Correa 1996). Vibrio species have been reported as one of the opportunistic pathogens from diseased Porphyra and Laminaria fronds (Wang et al. 2008). Usually, the secondary bacterial infection contributes to further disintegration of the infected tissue, finally leading to thallus rupture.

Bacterial decomposition of dead and drying macroalgae on the beaches is rapid, indicating the abundant presence of decomposing bacteria in the living algal community (Uyenco et al. 1981, Delille \& Perret 1991). A large proportion of bacteria in coastal waters are able to decompose macroalgal thalli (Uchida 1995, Uchida et al. 2002, Yoshimura et al. 2006). As bacteria are able to utilize algal nutrients selectively, they play a key role in the biotransformation (Chesters et al. 1956, Ramaiah \& Chandramohan 1992). They release a variety of compounds which are subsequently used by other organisms (Yaphe \& Baxter 1955, Yaphe 1962, Dimitrieva \& Dimitriev 1996, Sawabe et al. 1998b, Ivanova et al. 2002a,b, Sakai et al. 2002, Romanenko et al. 2003). Biotransformation and nutrient recycling is initiated by bacterial enzymes such as cellulases, alginases, fucoidanases, pectinases and agarases. Many of these enzymes have biotechnological applications (Yamasaki et al. 1998, Wong et al. 2000, Descamps et al. 2006, Wang et al. 2006, Kim et al. 2009). Despite the large number of associated bacteria, these lytic activities have been found only in a small number of genera (Table 2).

Pathogenic bacteria in host-associated biofilms cause significant mortality to their hosts or cause sig- 
nificant degradation of algal host tissue (Littler \& Littler 1995, Correa \& Sánchez 1996, Steinberg et al. 1997). Despite the prevalence of microbes in the ocean and the nature of pathogen-borne epidemics, diseases among marine macroalgae are rare (Table 3). This is even more remarkable, considering that algae do not have cell-based immune systems (Potin et al. 1999, Kubanek et al. 2003). However, evidence for induced defense reactions of algae upon pathogen recognition is emerging (Potin et al. 2002, Steinberg \& de Nys 2002, Weinberger et al. 2005, Weinberger 2007).

Bacterial infections of macroalgae may cause obvious but non-necrotic changes in morphology, appearance of holes in the thallus, or discolorations causing light or dark areas. It is also possible that they may not affect the visible appearance of the alga at all (Andrews 1976, Uyenco et al. 1981, Correa 1997). The association of bacteria with abnormal tissue growth (galls) on marine macroalgae is well known and has been found in more than 20 species of red and brown macroalgae (McBride et al. 1974, Tripodi \& Beth 1976, Tsekos 1982, Apt 1988 and literature therein). For example, bacterial symbionts of the Roseobacter group are able to cause such gall formations in the red macroalga Prionitis spp. (Ashen \& Goff 2000). The metabolic consequences of gall formation for the macroalgae and its bacterial inhabitants remain unknown. But apparently the hypertrophic growth of gall-induced algal cells provides a suitable microhabitat for proliferation of the 'symbiont' (Apt \& Gibor 1989, Ashen \& Goff 1998).

Table 3. Macroalgal diseases caused by bacteria. (-) not specified

\begin{tabular}{|c|c|c|c|}
\hline Macroalgae & Disease & Pathogen & Source \\
\hline \multicolumn{4}{|c|}{ Heterokontophyta, Phaeophyceae } \\
\hline Cystoseira nodicaulis & - & Unidentified Proteobacteria & Pellegrini \& Pellegrini (1982) \\
\hline Laminaria japonica & Hole-rotten disease & $\begin{array}{l}\text { Pseudoalteromonas, } \\
\text { Vibrio, Halomonas }\end{array}$ & Wang et al. (2008) \\
\hline Laminaria japonica & $\begin{array}{l}\text { Summer sporelings } \\
\text { disease }\end{array}$ & Micrococcus sp. & Wu (1990) \\
\hline Laminaria japonica & Red spot disease & $\begin{array}{l}\text { Pseudoalteromonas } \\
\text { bacteriolytica }\end{array}$ & $\begin{array}{l}\text { Ezura et al. (1988), Sawabe et al. } \\
\text { (1998b), Yumoto et al. (1989a,b) }\end{array}$ \\
\hline Laminaria japonica & Spot-wounded fronds & Pseudoalteromonas elyakovii & Sawabe et al. (2000) \\
\hline Undaria pinnatifida & Green decay diseases & Vibrio logei & Jiang et al. (1997) \\
\hline \multicolumn{4}{|l|}{ Rhodophyta } \\
\hline Chondrus crispus & - & $\begin{array}{l}\text { Cytophaga/Flavobacterium } \\
\text { group }\end{array}$ & $\begin{array}{l}\text { Correa \& McLachlan (1994), } \\
\text { Craigie \& Correa (1996) }\end{array}$ \\
\hline Gracilaria conferta & - & $\begin{array}{l}\text { Cytophaga/Flavobacterium } \\
\text { and Vibrio group }\end{array}$ & $\begin{array}{l}\text { Weinberger et al. (1997), } \\
\text { Weinberger \& Friedlander (2000b) }\end{array}$ \\
\hline Gracilaria gracilis & - & Undetermined bacteria & Jaffray \& Coyne (1996) \\
\hline Gracilaria gracilis & - & Pseudoalteromonas gracilis & Schroeder et al. (2003) \\
\hline Gracilaria sp. & Rotten thallus syndrome & Vibrio sp. & Lavilla-Pitogo (1992) \\
\hline Gracilaria verrucosa & Rotten thallus syndrome & Vibrio sp. & Beleneva \& Zhukova (2006) \\
\hline $\begin{array}{l}\text { Hydrolithon, Sporolithon, } \\
\text { Lithophyllum, Titanoderma } \\
\text { and other coralline algae }\end{array}$ & Thallus holes & Plectonema terebrans & $\begin{array}{l}\text { Ghirardelli (1998, 2002), Tribollet } \\
\text { \& Payri (2001) }\end{array}$ \\
\hline Kappaphycus alvarezii & Ice-ice whitening & $\begin{array}{l}\text { Cytophaga-Flavobacterium } \\
\text { group-Vibrio group }\end{array}$ & $\begin{array}{l}\text { Largo et al. }(1995,1999), \\
\text { Vairappan et al. }(2008)\end{array}$ \\
\hline Mazzaella laminarioides & Deformative disease & Pleurocapsa sp. & $\begin{array}{l}\text { Buschmann et al. (1997), } \\
\text { Correa et al. (1993) }\end{array}$ \\
\hline $\begin{array}{l}\text { Porolithon onkodes } \\
\text { and other coralline algae }\end{array}$ & $\begin{array}{l}\text { Coralline lethal orange } \\
\text { disease (CLOD) }\end{array}$ & - & $\begin{array}{l}\text { Aeby (2007), Littler \& Littler } \\
(1994,1995)\end{array}$ \\
\hline Porphyra leucosticta & White rot disease & Vibrio sp. & Tsukidate $(1977,1983)$ \\
\hline Porphyra leucosticta & Suminori & Flavobacterium sp. & Kusuda et al. (1992) \\
\hline Porphyra yezoensis & Green spot rotting & Vibrio sp., Pseudomonas sp. & $\begin{array}{l}\text { Fujita et al. (1972), Nakao } \\
\text { et al. (1972) }\end{array}$ \\
\hline Porphyra yezoensis & Anaaki & Flavobacterium sp. & Sunairi et al. (1995) \\
\hline
\end{tabular}




\section{BENEFICIAL BACTERIAL-MACROALGAL INTERACTIONS}

The role of epiphytic bacteria in maintaining the health of the host has received little attention. Though beneficial associations between bacteria and their host have been identified (Cole 1982, Weinberger et al. 1997, Dobretsov \& Qian 2002, Rao et al. 2006), the advantages for algae are less obvious (Marshall et al. 2006).

\section{Nutritional aspects and growth factors}

Beneficial relationships may be based on the algal capacity to produce organic compounds and oxygen which are utilized by bacteria (Brock \& Clyne 1984, Coveney \& Wetzel 1989). In turn, bacteria mineralize organic substrate, supplying the algae with carbon dioxide, minerals and growth factors (Croft et al. 2005, 2006). Several studies indicated that marine epiphytic bacteria are important sources of fixed nitrogen for algae. Diverse epiphytic Cyanobacteria (Calothrix sp., Anabaena sp., and Phormidium sp.) that fix nitrogen and supply it to Codium species (Chlorophyta) have been described from certain locations (Dromgoole et al. 1978, Rosenberg \& Paerl 1981). Another nitrogen fixer, Dichothrix fucicola, was located in association with populations of Sargassum natans and S. fluitans in the Sargasso Sea and the Gulf Stream (Carpenter 1972, Carpenter \& Cox 1974). The nitrogen supply of Caulerpa taxifolia is provided by an endosymbiotic bacterium from the Agrobacterium-Rhizobium group, living in the algal rhizoids (Chisholm et al. 1996). A significant nitrogenase activity was attributed to the nitrogen-fixing Azotobacter sp., present on the macroalga Codium fragile subsp. tomentosoides (Head \& Carpenter 1975), indicating nitrogen fixation within the association.

These associations secure the supply of dinitrogen to the macroalgae and might be one of the reasons for the successful invasion of these noxious macroalgae (like Caulerpa taxifolia or Codium fragile) into oligotrophic environments (Chisholm et al. 1996). Indeed, in other aquatic environments, some epiphytic Cyanobacteria like Nostoc sp., Calothrix sp. and Anabaena sp., living on the green macroalga Chara vulgaris seem to be the main nitrogen contributors (Ariosa et al. 2004).

In addition to nitrogen fixation, microbes play a role in the protection of the macroalga against toxic compounds such as heavy metals (Riquelme et al. 1997, Dimitrieva et al. 2006) or crude oil (Semenova et al. 2009). Microorganisms are able to detoxify, for example, heavy metals by precipitation, adsorption, or transformation to less toxic forms (Yurkov \& Beatty 1998).
Bacteria also supply macroalgae with growth factors, e.g. by involvement in the production and turnover of various phytohormones and biostimulators of cell growth and development (Berland et al. 1972, Bolinches et al. 1988, Meusnier et al. 2001). For example, a favorable growth-promoting effect by the bacterium Pseudoalteromonas porphyrae was observed on Laminaria japonica (Dimitrieva et al. 2006). Plant hormone production seems to be widespread in various genera of marine bacteria. Maruyama et al. (1990) demonstrated that bacteria produce more cytokinin-type and auxin-type hormones when associated with macroalgae as compared to planktonic bacteria. Previous studies showed the ability of bacteria living on Ulva spp. (formerly Enteromorpha) to convert tryptophan into the phytohormone indole-3-acetic acid (IAA) (Fries 1975). In the macroalga Prionitis lanceolata, the gall formation mentioned above is associated with a bacterium of the Roseobacter group. IAA is overproduced in those algal galls in comparison to the rest of the thallus. Although the role of the bacterium in the physiology of the macroalga is not well understood, a coevolution has been suggested (Ashen et al. 1999, Ashen \& Goff 2000).

\section{Impact on macroalgal morphology}

Beside nutrititional and growth promoting effects, bacteria affect the morphology and life cycle of macroalgae. Marine foliaceous green macroalgae such as Ulva spp. drastically lose their typical morphology when cultured aseptically (Fries 1975, Provasoli \& Pintner 1980, Tatewaki et al. 1983). This phenomenon was also observed in the red macroalgae Dasya pedicellata C. Agardh and Polysiphonia urceolata (Dillwyn) Greville (Provasoli \& Pintner 1972). Addition of adequate marine bacteria or their culture filtrates restored the typical morphology of these macroalgae (Nakanishi et al. 1999). Actually, morphogenesis in such macroalgae (Ulvaceae and Monostromaceae) is controlled by a restricted group of bacteria of the Bacteroidetes phylum, mainly Cytophaga and Flavobacterium spp. (Hanzawa et al. 1998, Nakanishi et al. 1999, Matsuo et al. 2005, Marshall et al. 2006). Furthermore, morphogenic effects on macroalgae were also demonstrated for members of the genera Caulobacter, Vibrio, Pseudomonas, Deleya, Escherichia and some Gram-positive bacteria (Nakanishi et al. 1996). These bacteria lose their ability to induce morphogenic effects when grown alone for several generations in marine media containing rich organic sources, but regain it under co-cultivation with Ulva in synthetic mineral media. Both 'partners' apparently depend on the metabolites produced by the other (Provasoli \& Pintner 1980). 
Thallusin was the first compound identified to induce thallus differentiation in macroalgae. It was produced from an epiphytic marine bacterium isolated from the alga Monostroma sp. (Matsuo et al. 2003). In order to maintain the common algal morphology, this compound has to be constantly supplied by the bacterium. Thallusin exemplifies a fundamental symbiotic chemical communication between macroalgae and epiphytic bacteria in the marine environment (Matsuo et al. 2005). However, the mechanism of modulation of algal morphology by thallusin is not yet understood (Marshall et al. 2006).

\section{Effect on spore germination and macroalgal colonization}

Recently, it was discovered that bacterial biofilms play a role in spore germination and subsequent colonization of new substrates by algae. A set of diverse bacterial species isolated from marine surfaces colonized by Ulva spp. either stimulated or inhibited the zoospore settlement of this green macroalgae (Patel et al. 2003, Tait et al. 2005). Phylogenetic analysis revealed that the isolated bacteria belonged to the Gammaproteobacteria, the Cytophaga-FlavobacteriaBacteroidetes group and Alphaproteobacteria. Most of these microorganisms revealing stimulating effects were strains of Vibrio and Shewanella species. Effects on spore settlement were strain- but not species-specific, and the activity varied with the age of the biofilm. A positive correlation between zoospore settlement of Ulva linza and bacterial biofilm density indicates the important role of bacterial biofilms in the development of algal communities (Marshall et al. 2006).

It appears that these are not isolated cases. Of the 192 bacterial strains isolated from the surfaces of seaweeds from China, 63 isolates were shown to be inhibitory against the settlement of algal spores (Ma et al. 2009). Also, a number of diverse bacterial metabolites affect the germination of spores of various macroalgae (Egan et al. 2001b, Matsuo et al. 2003, Dimitrieva et al. 2006) (Table 4). For example, an antialgal peptide that inhibited spore germination was produced by Pseudoalteromonas tunicata isolated from Ulva australis (Egan et al. 2001b). The fatty acids cis-9-oleic acid and 2-hydroxymyristic acid produced by the bacterium Shewanella oneidensis (Bhattarai et al. 2007) as well as a peptidic compound produced by the bacterium Alteromonas sp. (isolated from the red alga Rhodymenia sp.) exhibited activity against spores of U. lactuca (Silva-Aciares \& Riquelme 2008).

As mentioned, bacterial biofilms play an important role in initiation of colonization processes. A preferential settlement of spores on specific bacterial biofilms producing morphogenic compounds may facilitate a close association of the developing macroalgae with these specific bacterial 'episymbionts' (Joint et al. 2002, Patel et al. 2003). As we discuss later, these epibionts play a protective role by releasing compounds into the surrounding seawater that prevent extensive biofouling of the surface or act against microbial pathogens (Armstrong et al. 2001, Wiese et al. 2009b).

\section{CHEMICAL INTERACTIONS}

Since the 1970s it has been known that chemical compounds are the basis of many aspects of communication and molecular interaction between aquatic organisms (Bhakuni \& Silva 1974, Scheuer 1978, Hay 2009). However, studies on these chemical interactions within marine communities are relatively new as compared to the analyses of feeding relationships (Paul \& Puglisi 2004). More intense investigations of the large variety of interactions between hosts and microbes and between different microbes should reveal the different communication pathways, which include the production of defensive or deterrent compounds, pheromones, attractants and other signal substances. Some of these compounds act in a general way while others have highly specific modes of action (Davies et al. 1998, Rasmussen et al. 2000, Da Gama et al. 2002). Chemically mediated interactions like fertilization, allelopathy, and prey detection between macroalgae and other marine organisms fundamentally depend on the sensing of chemicals at or near surfaces (Steinberg \& de Nys 2002). It has been demonstrated that the microbial colonization of various host organisms might be controlled by host-derived molecules (Wahl et al. 1994, Rao \& Fujita 2000). However, little is known about the potential role of secondary metabolites in the regulation and development of associations. Other chemically mediated types of microbial behaviors such as chemotaxis, adhesion, swarming and biofilm formation are much better understood (Parsek \& Greenberg 2000, Ren et al. 2002, Qian et al. 2007).

\section{Antibiotic activities of macroalga-associated bacteria}

Antimicrobial activity is widespread among algaassociated bacteria. Wiese et al. (2009b) showed that almost $50 \%$ of a total of 210 isolates of the epiphytic bacterial community of Saccharina latissima (Baltic Sea, Germany) inhibited the growth of at least one microorganism from a panel covering Gram-negative and Gram-positive bacteria. Burgess et al. (1999) demonstrated that $35 \%$ of the surface-associated bacteria isolated from various macroalgae and invertebrates in 
Table 4. Bioactive compounds produced by macroalgal associated bacteria. AF = antifungal activity, AP = antiprotozoal activity, AS = antisettlement activity, GNI = antibiotic activity against Gram-negative bacteria, GPI = antibiotic activity against Grampositive bacteria, $\mathrm{MG}=$ morphogenesis activity, $\mathrm{PH}=$ photosynthetic compound

\begin{tabular}{|c|c|c|c|c|c|}
\hline Compound & Chemical class & Activity & Producing bacterium & Macroalgae & Source \\
\hline $\begin{array}{l}2,4 \text { dibromo-6- } \\
\text { chlorophenol }\end{array}$ & $\begin{array}{l}\text { Halogenated } \\
\text { phenol }\end{array}$ & GPI & $\begin{array}{l}\text { Pseudoalteromonas } \\
\text { luteoviolacea }\end{array}$ & Padina australis & Jiang et al. (2001) \\
\hline $\begin{array}{l}\text { 2,4-diacetyl } \\
\text { phloroglucinol }\end{array}$ & Phenol & GPI & Pseudomonas sp. & $\begin{array}{l}\text { Ceratodyction } \\
\text { spongiosum }\end{array}$ & $\begin{array}{l}\text { Isnansetyo et al. } \\
\text { (2001) }\end{array}$ \\
\hline Chlorophyll $d$ & Pyrrole & PH & Acaryochloris sp. & $\begin{array}{l}\text { Ahnfeltiopsis } \\
\text { flabelliformis }\end{array}$ & $\begin{array}{l}\text { Murakami et al. } \\
(2004)\end{array}$ \\
\hline $\begin{array}{l}\text { Cyclo-[isoleucyl- } \\
\text { prolylleucyl-alanyl] }\end{array}$ & Tetrapeptide & GPI & $\begin{array}{l}\text { Pseudoalteromonas } \\
\text { sp. }\end{array}$ & Digenea sp. & $\begin{array}{l}\text { Rungprom et al. } \\
\text { (2008) }\end{array}$ \\
\hline $\begin{array}{l}\text { Cyclo-(L-prolyl- } \\
\text { L-glycine) }\end{array}$ & Diketopiperazines & GPI & $\begin{array}{l}\text { Pseudoalteromonas } \\
\text { luteoviolacea }\end{array}$ & Padina australis & Jiang et al. (2001) \\
\hline $\begin{array}{l}\text { Cyclo-(L-phenyl alanyl-4R)- } \\
\text { hydroxy-L-proline }\end{array}$ & Diketopiperazines & GPI & $\begin{array}{l}\text { Pseudoalteromonas } \\
\text { luteoviolacea }\end{array}$ & Padina australis & Jiang et al. (2001) \\
\hline Haliangicin & $\beta$-methoxyacrylate & $\mathrm{AF}$ & Haliangium luteum & $\begin{array}{l}\text { Undetermined } \\
\text { algae }\end{array}$ & Fudou et al. (2001) \\
\hline Korormicin & $\gamma$-lactone derivate & GNI & $\begin{array}{l}\text { Pseudoalteromonas } \\
\text { sp. F-420 }\end{array}$ & Halimeda sp. & $\begin{array}{l}\text { Yoshikawa et al. } \\
\text { (1997) }\end{array}$ \\
\hline Macrolactines G, M & Lactones & GPI & Pseudomonas sp. & Red algae & $\begin{array}{l}\text { Gerard et al. } \\
(1997)\end{array}$ \\
\hline Macrolactines G, M, A, F & Lactones & GPI & $\begin{array}{l}\text { Bacillus sp. } \\
\text { PP19-H3 }\end{array}$ & $\begin{array}{l}\text { Schizymenia } \\
\text { dubyi }\end{array}$ & Nagao et al. (2001) \\
\hline Massetolide A & Lipopeptide & GPI & Pseudomonas sp. & Red algae & $\begin{array}{l}\text { Gerard et al. } \\
(1997)\end{array}$ \\
\hline Pelagiomycin A & Phenazine & $\begin{array}{l}\text { GPI, } \\
\text { GNI }\end{array}$ & $\begin{array}{l}\text { Pelagiobacter } \\
\text { variabilis }\end{array}$ & $\begin{array}{c}\text { Pocockiella } \\
\text { variegata }\end{array}$ & $\begin{array}{l}\text { Imamura et al. } \\
(1997)\end{array}$ \\
\hline- & Peptide & AS & $\begin{array}{l}\text { Pseudoalteromonas } \\
\text { tunicata }\end{array}$ & Ulva lactuca & Egan et al. (2001b) \\
\hline- & Peptide & AS & $\begin{array}{l}\text { Alteromonas sp. } \\
\text { Ni1-LEM }\end{array}$ & Rhodymenia sp. & $\begin{array}{l}\text { Silva-Aciares \& } \\
\text { Riquelme (2008) }\end{array}$ \\
\hline Protein $30,7 \mathrm{kDa}$ & Protein & GPI & $\begin{array}{l}\text { Bacillus } \\
\text { licheniformis }\end{array}$ & Fucus serratus & Jamal et al. (2006) \\
\hline Thallusin & Pyridine & MG & $\begin{array}{l}\text { Cytophaga/ } \\
\text { Flavobacterium/ } \\
\text { Bacteroidetes group }\end{array}$ & Monostroma sp. & $\begin{array}{l}\text { Matsuo et al. } \\
(2003)\end{array}$ \\
\hline Violacein & Alkaloid & $\mathrm{AP}$ & $\begin{array}{l}\text { Pseudoalteromonas } \\
\text { tunicata, P. ulvae }\end{array}$ & Ulva australis & Matz et al. (2008) \\
\hline YP1 & Tambjamine & $\mathrm{AF}$ & $\begin{array}{l}\text { Pseudoalteromonas } \\
\text { tunicata }\end{array}$ & Ulva australis & Franks et al. (2006) \\
\hline
\end{tabular}

Scottish waters produced antimicrobial substances. From a total of 280 strains isolated from 7 macroalgae, $21 \%$ showed antibacterial activity (Boyd et al. 1999b). Of the isolates from 9 brown macroalgae, 20\% were antibiotically active as were $33 \%$ of the isolates from 9 red algae collected from Japanese waters of the Pacific Ocean (Kanagasabhapathy et al. 2006, 2008). Penesyan et al. (2009) obtained 325 bacterial isolates from the surface of Delisea pulchra and Ulva australis in Australia and demonstrated antibiotic activity of $12 \%$ of the strains. Microbulbifer sp. was the dominant biological active bacterium in this study.
Antimicrobial active isolates from all mentioned macroalgae were phylogenetically assigned to diverse genera comprising Pseudomonas, Pseudoalteromonas, Stenotrophomonas, Vibrio, Aeromonas, Shewanella, Streptomyces and Bacillus species (Wiese et al. 2009b). Many Bacillus species are efficient producers of antimicrobial compounds and therefore highly successful colonizers of macroalgal surfaces (Trischman et al. 2004, Kanagasabhapathy et al. 2006). Most of the isolates with high antifouling activity obtained by Burgess et al. (2003) were identified as Bacillus species, i.e. B. pumilus, B. licheniformis and B. subtilis. Besides 
Bacillus species, Pseudoalteromonas spp. are commonly found on marine macroalgae (Wang et al. 2008). Many of them also produce biologically active molecules (Holmström et al. 1998, Kalinovskaya et al. 2004, Skovhus et al. 2007). For example, 3 epiphytic strains of Pseudoalteromonas sp. isolated from Ulva lactuca were able to inhibit the growth of a variety of bacteria and fungi (Egan et al. 2000, 2001a,b): P. tunicata was able to prevent biofouling by growth inhibition of other surface-associated microorganisms. For this purpose, it produced at least 5 target-specific compounds (Holmström et al. 1992, James et al. 1996) (Table 4), including a large antibacterial protein (James et al. 1996), a small polar heat-stable anti-larval molecule (Holmström et al. 1992), a putative antialgal peptide (Egan et al. 2001b), an antifungal alkaloid (Franks et al. 2006) and also violacein, a purple pigment that inhibits protozoan grazing (Matz et al. 2008). This chemical arsenal has been shown to be important for the survival of $P$. tunicata in its highly competitive marine surface environment (Rao et al. 2005, 2007, Thomas et al. 2008, and references therein). Production of a range of compounds active against a variety of target organisms is a characteristic feature of these bacteria and may largely promote their competition and colonization of algal surfaces (Holmström \& Kjelleberg 1999, Patel et al. 2003, Rao et al. 2005).

Bacteria producing antibiotic substances reflect an important part of bacterial communities on surfaces of marine organisms as compared to free-living bacterial communities (Mearns-Spragg et al. 1998, Zheng et al. 2005, Kanagasabhapathy et al. 2008). However, we still have a long way to go in understanding how bacteria really protect their hosts and what kind of compounds they may produce under the multifactorial natural conditions in situ (Bode et al. 2002). For example, a marine actinomycete (SS-228) was shown to produce an antibiotic compound only when the growth medium was supplemented with Laminaria sp., a macroalgae common in the habitat from which the strain was obtained (Okazaki et al. 1975). Inhibitory activities against other epiphytic bacteria are of great importance in microhabitats such as an algal surface, where competition for an attachment site is frequent (Lemos et al. 1985, Mearns-Spragg et al. 1998, Yan et al. 2002, Rao et al. 2007).

\section{Chemical defense of macroalgae against microorganisms}

The defending interaction of macroalgae with biofilms is well documented and the surfaces of many macroalgae remain relatively free of epibiosis. However, few studies have investigated if secondary metabolites are released from macroalgae and affect planktonic bacteria directly (Nylund \& Pavia 2005, Paul et al. 2006, Dubber \& Harder 2008, Lam et al. 2008a). Lu et al. (2008) showed that macroalgae like Ulva clathrata have an inhibitory effect on Vibrio anguillarum, a fish and mussel pathogen, although not reducing the total amount of heterotrophic bacteria. This effect was explained by some unknown chemical substances, either released from U. clathrata or produced by the alga-associated microorganisms. Recently, Pang et al. (2006a) observed that in polycultures with the red macroalga Gracilaria textorii the total number of Vibrio species ( $V$. alginolyticus and $V$. logei) was controlled. Even more, after inoculation of $V$. parahaemolyticus into cultures of the red macroalga Grateloupia turuturu, the bacterium was inhibited in its growth and finally disappeared from the cultures (Pang et al. 2006b).

\section{Antibiotic activities of macroalgal extracts and metabolites}

Given that algae lack cell-based immune responses and are continuously exposed to a broad array of potentially deleterious microorganisms, it is reasonable to hypothesize that the production of bioactive secondary metabolites acts as a fundamental mechanism of antimicrobial defense to deter microbial attack (Engel et al. 2002). Macroalgae may secrete antifouling compounds into the surrounding seawater and retain antigrazing compounds within the thallus structure (Armstrong et al. 2001). The production of inhibitory substances from macroalgae was noted as early as in 1917 (Ara 2001) and since then the antibacterial activity of extracts of macroalgae has been described in many studies around the world (Yan et al. 2003, Bhakuni \& Rawat 2005, Puglisi et al. 2007, Dubber \& Harder 2008, and literature therein) (Table 5). Many different compounds produced by macroalgae exhibit antibiotic activity, for example fatty acids, phenols, acetylenes, various terpenes, coumarins, carbonyls, and polysaccharides (Bhakuni \& Silva 1974, Hoppe et al. 1979 and literature therein, Ballantine et al. 1987, Lustigman et al. 1992, Lobban \& Harrison 1996, Steinberg et al. 1997, Potin et al. 1999, Ara 2001, Sandsdalen et al. 2003; Table 5). These biological activities might have a protective function by elimination or control of the number of pathogens, epiphytes or endophytes (Hornsey \& Hide 1976b, Hoppe et al. 1979, Smit 2004, Plouguerne et al. 2008).

While a large proportion of the literature deals with antimicrobial activities of marine macroalgal extracts and secondary metabolites (Table 5), little is known about how these compounds act in an ecological con- 
Table 5. Examples of antimicrobial and antifouling compounds isolated from macroalgae. $\mathrm{AV}=$ antiviral, $\mathrm{AE}=\mathrm{antifouling}, \mathrm{AF}=$ antifungal activity, GNI = antibiotic activity against Gram-negative bacteria, GPI = antibiotic activity against Gram-positive bacteria

\begin{tabular}{|c|c|c|c|}
\hline Macroalga & Compounds & Activity & Source \\
\hline \multicolumn{4}{|l|}{ Chlorophyta } \\
\hline Avrainvillea nigricans & 5'-hydroxy isoavrainvilleol & GPI & Colon et al. (1987) \\
\hline Caulerpa spp. & Sesquiterpenoids & GPI, GNI & Paul et al. (1987) \\
\hline Codium iyengarii & Iyengaroside-A, clerosterol galactoside & GPI, GNI & Ali et al. (2002) \\
\hline Penicillus capitatus & Capisterones A, B & $\mathrm{AF}$ & Puglisi et al. (2004) \\
\hline Tydemania expeditionis & Sulphated triterpenoids & $\mathrm{AF}$ & Jiang et al. (2008) \\
\hline Ulva fasciata & Labdane diterpenoids & GNI & Chakraborty et al. (2010) \\
\hline \multicolumn{4}{|l|}{ Heterokontophyta, Phaeophyceae } \\
\hline Canistrocarpus cervicornis & Diterpenes & $\mathrm{AE}$ & Bianco et al. (2009) \\
\hline Cystoseira spinosa var. squarrosa & Tetraprenyltoluquinol & GPI, GNI & Amico et al. (1988) \\
\hline Cystoseira tamariscifolia & Methoxybifurcarenone & GNI & Bennamara et al. (1999) \\
\hline Dictyotaceae & Dolabellane derivatives & $\mathrm{AF}$ & Tringali et al. (1986) \\
\hline Dictyopteris zonarioides & Zonarol \& isozonarol & $\mathrm{AF}$ & Fenical et al. (1973) \\
\hline Dictyota menstrualis & Dictyol D, pachydictyol A & $\mathrm{AE}$ & Schmitt et al. (1995) \\
\hline Dilophus guineensis & Dilophic acid & GPI & Schlenk \& Gerwick (1987) \\
\hline Dilophus okamurai & Spatane-type diterpenes & $\mathrm{AE}$ & Kurata et al. (1988) \\
\hline Fucus vesiculosus & Polyhydroxylated fucophlorethol & GPI, GNI & Sandsdalen et al. (2003) \\
\hline Landsburgia quercifolia & 1,4-naphthoquinone & GPI, AF & Perry et al. (1991) \\
\hline Lobophora variegata & Lobophorolide & $\mathrm{AF}$ & Kubanek et al. (2003) \\
\hline Sargassum spp. & Polyphenols & $\mathrm{AE}, \mathrm{GNI}$ & Sieburth \& Conover (1965) \\
\hline Stoechospermum marginatum & Spatane diterpenoids & GPI & De Silva et al. (1982) \\
\hline Stoechospermum marginatum & Sulfated fucan & AV & Adhikari et al. (2006) \\
\hline \multicolumn{4}{|l|}{ Rhodophyta } \\
\hline Asparagopsis armata & Halomethanes, haloether, haloacetales & GPI, GNI & Paul et al. (2006) \\
\hline Bonnemaisonia hamifera & Poly-brominated 2- heptanone & GNI & Nylund et al. (2008) \\
\hline Callophycus serratus & Bromophycolides & $\mathrm{AF}$ & Lane et al. (2009 \\
\hline Dasya pedicellata var. stanfordiana & P-hydroxybenzaldehyde & GPI, GNI & Fenical \& McConnell (1976) \\
\hline Delesseriaceae & Almazole D & GNI & N'Diaye et al. (1996) \\
\hline Delisea pulchra & Halogenated furanones & $\mathrm{AE}$ & Maximilien et al. (1998) \\
\hline Delisea pulchra & Halogenated furanones & GPI, GNI & Wright et al. (2006) \\
\hline Grateloupia indica & Galactan sulphate & AV & Chattopadhyay et al. (2007) \\
\hline Laurencia chilensis & 3-hydroxi-4-methyl acetophenone & GPI, GNI & Valdebenito et al. (1982) \\
\hline Laurencia majuscula & Brominated sesquiterpenes & GPI, GNI & Vairappan et al. (2010) \\
\hline Laurencia pannosa & Pannosanol, pannosane & GNI & Suzuki et al. (2001a) \\
\hline Laurencia spp. & Laurinterol, isolaurinterol & GNI & Vairappan et al. (2001b) \\
\hline Laurencia spp. & Brominated sesquiterpenes & GPI, GNI & Bansemir et al. (2004) \\
\hline Osmundaria serrata & Lanosol ethyl ether & GPI, GNI, AF & Barreto \& Meyer (2006) \\
\hline Rhodomela confervoides & Bromophenols & GPI, GNI & Xu et al. (2003) \\
\hline Sphaerococcus coronopifolius & $\begin{array}{l}\text { Bromosphaerone, } \\
\text { 12S-hydroxybromosphaerodiol }\end{array}$ & GPI & Etahiri et al. (2001) \\
\hline
\end{tabular}

text (Engel et al. 2002). Engel et al. (2006) explored the antimicrobial effects of extracts from several marine macroalgae against algal saprophytes, parasites, and pathogens. It was concluded that the antimicrobial metabolites selectively target marine microorganisms, although the susceptibility of ecologically relevant bacteria has rarely been studied (Yoshikawa et al. 1997, Puglisi et al. 2007, Kanagasabhapathy et al. 2008).

From an ecological perspective, antimicrobial defense mechanisms of marine macroalgae may reduce epibiosis, inhibit premature decomposition and directly provide resistance to infectious diseases (Engel et al. 2006). The required defense substances may be expressed constitutively or may be induced in response to contact with the target organisms and their chemical signals, respectively (Cronin \& Hay 1996, Amsler \& Fairhead 2005). The inducible defense allows metabolic cost savings and is advantageous due to a lower risk of autotoxicity and resistance adaptation (Macaya et al. 2005, Medeiros et al. 2007, Macaya \& Thiel 2008). An increasing number of studies is related to the induced defense mechanisms of macroalgae against herbivores. Research on the induced defense mechanisms against microbial pathogens or epibiosis is still limited. Recently, Vairappan et al. (2010) were the first to demonstrate the highly selective antibiotic activity of extracts from the epiphytic macroalga Laurencia majuscula against 6 algal pathogenic bacteria. They 
were able to identify 4 halogenated compounds whose concentration increased more than $120 \%$ during an ice-ice disease outbreak in the host basibiont, the macroalga Kappaphycus alvarezii (Table 5). Interestingly, in another species of these red macroalgae, Laurencia obtusa, the dynamics of vesicle transport from corps en cerise (specific structures where those macroalgae accumulate these halogenated secondary metabolites) and their eventual exocytosis were shown to be induced in relation to bacterial biofilms (Paradas et al. 2010). The authors suggested a direct correlation with this process and the inhibition of microfouling on the macroalgal surface.

\section{Oxidative burst-an antibacterial response of macroalgae}

In addition to the production of antibiotic compounds, macroalgae are able to use oxidative burst as a defense mechanism as described for higher plants (Weinberger et al. 1999, 2002, Dring 2005, Ar Gall et al. 2008). This process is a non-specific defense response against surface colonization typically characterized by a rapid activation of reactive oxygen species causing death of the pathogen (Bouarab et al. 1999, Weinberger \& Friedlander 2000a,b, Steinberg \& de Nys 2002, Potin 2008). The oxidative burst is triggered by cell-cell recognition, involving the perception of signal molecules or cell wall compounds from the invading organism by the algal cell membrane (Küpper et al. 2006). Common elicitors of non-specific host responses are oligosaccharides, glycoproteins, and glycopeptides (Küpper et al. 2001). Recently, other compounds such as methyl jasmonate and free fatty acids (in particular arachidonic and linolenic acid) were also found to be strong triggers of an oxidative burst in Laminaria digitata (Küpper et al. 2009). In particular, the elicitation of defense mechanisms by oligosaccharides has been studied in macroalgae (e.g. Potin et al. 1999, Ar Gall et al. 2008). This involves the degradation of the host cellwall polysaccharides by enzymes released from various pathogens, comprising epiphytic bacteria (Weinberger et al. 1999, Weinberger \& Friedlander 2000a,b, Küpper et al. 2002) and algal endophytes (Bouarab et al. 1999, Küpper et al. 2002). This was shown for the brown alga L. digitata, where oligosaccharides derived from alginate elicit a distinct oxidative burst in the cortical cells of sporophytes and thereby control the populations of epiphytic bacteria (Küpper et al. 2001). Küpper et al. (2002) investigated 45 species of brown algae with regard to their ability to respond to oligoalginates with an oxidative burst. They found that a total of 15 macroalgal species reacted, all of them belonging to an alginate-rich group with complex thal- lus morphology. But there is also evidence for a constitutive release of hydrogen peroxide in red macroalgae e.g. Solieria chordalis, as a mechanism to prevent both the establishment of bacterial biofilms and the subsequent development of algal epiphytes (Ar Gall et al. 2008). In addition to algal elicitors, Küpper et al. (2006) demonstrated that components of the outer membranes of Gram-negative bacteria may be considered as exogenous elicitors in brown macroalgae. In the red agarophyte Gracilaria conferta bacterial elicitors are presumably represented by a low-molecular weight peptide (Weinberger \& Friedlander 2000a).

These results demonstrate that defense pathways exist in marine macroalgae which are similar to those known from animals and land plants (Bouarab et al. 2004, Weinberger 2007). Interestingly, the oxidative burst is known to direct a variety of secondary defense responses like the generation and release of volatile halogenated compounds and the peroxidation of fatty acids (Küpper et al. 2001, 2006, Weinberger et al. 2002, Cosse et al. 2007, Potin 2008). Induction of the oxidative burst within red and brown macroalgae is followed by a rapid increase in emission of iodine-containing halocarbons, molecular iodine, and also in the brominating activity (Weinberger et al. 1999, Palmer et al. 2005).

\section{Quorum sensing and its role in bacterial-macroalgal interactions}

Quorum sensing (QS) is a cell to cell communication mechanism that allows bacteria to coordinate swarming, biofilm formation, stress resistance, and production of secondary metabolites in response to an excess of the threshold of QS signals (Paul \& Ritson-Williams 2008, Dobretsov et al. 2009). Gram-negative bacteria, such as Pseudomonas or Vibrio strains, produce $N$-acyl homoserine lactones (AHLs) as signalling compounds. Pseudomonas spp. are also known to produce diketopiperazines acting as QS signals (Dickschat 2010). The signal molecules $\gamma$-butyrolactones and oligopeptides are known to be synthesized by Gram-positive bacteria, e.g. members of the genera Streptomyces or Bacillus (reviewed by Dobretsov et al. 2009).

The interaction between zoospores of eukaryotic green macroalgae (Ulvales) with Vibrio anguillarum indicates algal susceptibility to quorum sensing AHL molecules (Joint et al. 2002, Wheeler et al. 2006). Although the specific mechanism regulating these responses to AHLs is not known, it was shown that the AHL molecules affect the calcium influx into the spores of Ulva sp., affecting their motility towards the surfaces where they eventually settle (Diggle et al. 2007, Joint et al. 2007). In addition, it has been demonstrated that 
life cycle completion and spore release in the red epiphytic alga Acrochaetium sp. strongly depend on AHLs, which are produced by bacteria associated with the algal basibiont Gracilaria chilensis (Weinberger et al. 2007). These findings of AHL perception in green and red algae confirm that AHL signalling is more widespread among eukaryotes than previously thought. This indicates a more general importance of the associated microbial communities in interactions with macroalgae. As we mentioned before, bacterial biofilms play an important role in the development of macroalgal communities. Hence, the ability to exploit a bacterial sensory system makes an important contribution to the ecological success of macroalgae (Tait et al. 2005, Joint et al. 2007).

Algae reduce harmful effects by controlling bacterial colonization by interfering with the bacterial QS systems, which regulate several bacterial traits related to colonization (Gram et al. 1996, Steinberg et al. 1997, Dworjanyn et al.1999). During the past decade it has been shown that various macroalgae are able to stimulate, inhibit or inactivate QS signals in bacteria by producing QS inhibitors or analogues thereof (Maximilien et al. 1998, Joint et al. 2007, Kanagasabhapathy et al. 2009, Table 6). The Australian red macroalga Delisea pulchra produces halogenated furanones, structural analogues to $N$-acyl homoserine lactones. These furanones protect the algal surfaces by interfering with AHL-regulated processes and selectively inhibit bacterial colonization and biofilm formation (Maximilien et al. 1998, Rasmussen et al. 2000, Manefield et al. 2002). In addition to the furanones of $D$. pulchra, a variety of bacteria and eukaryotes have been shown to produce cyclic dipeptides that can act as AHL mimics and affect QS-regulated behaviour in other bacteria (Dobretsov et al. 2009, Dickschat 2010). Recently, Kanagasabhapathy et al. (2009) suggested that certain epibiotic bacteria from the brown macroalgae Colpomenia sinuosa may play a role in defense mechanisms and suppress the settlement of other competitive bacteria by producing quorum sensing inhibitors (QSI) or QSI-like compounds. AHL-antagonists and inhibitors of the AHL regulatory system lead to an inhibition of bacterial colonization in an entirely different way from antibiotic substances (Givskov et al. 1996, Manefield et al. 1999, 2002). Their action results in lower bacterial abundance on the algal surface relative to other surfaces that are not controlled by such or similar mechanisms (Maximilien et al. 1998, Steinberg \& de Nys 2002).

\section{BIOSYNTHETIC ORIGIN OF BIOLOGICALLY ACTIVE METABOLITES}

Macroalgae are prolific natural product synthesizers. Until now, approximately 2000 secondary metabolites have been isolated from these algae, most of them displaying biological activities (Medeiros et al. 2007). Nevertheless, marine microorganisms have also been shown to be an important source for novel natural products (Fenical 1993, Penesyan et al. 2010). Considering that so far virtually all macroorganisms collected and extracted for chemical studies include the associated microorganisms, questions about the true biosyn-

Table 6. Quorum sensing (QS) inhibitors observed in algae (modified from Dobretsov et al. 2009). AHL = N-acyl homoserine lactones

\begin{tabular}{|c|c|c|c|}
\hline Algae & Compound & Activity & Source \\
\hline \multicolumn{4}{|l|}{ MICROALGAE } \\
\hline $\begin{array}{l}\text { Chlorophyta } \\
\text { Chlamydomonas reinhardtii }\end{array}$ & Lumichrome & Mimic AHL signals & $\begin{array}{l}\text { Rajamani et al. (2008), } \\
\text { Teplitski et al. (2004) }\end{array}$ \\
\hline \multicolumn{4}{|l|}{ MACROALGAE } \\
\hline \multicolumn{3}{|l|}{ Chlorophyta } & Skindersoe et al. (2008) \\
\hline \multicolumn{4}{|c|}{ Heterokontophyta, Phaeophyceae } \\
\hline Laminaria digitata & Hypobromous acid & $\begin{array}{l}\text { Deactivates AHL by } \\
\text { interfering with QS genes }\end{array}$ & Borchardt et al. (2001) \\
\hline \multicolumn{4}{|l|}{ Rhodophyta } \\
\hline Ahnfeltiopsis flabelliformis & $\begin{array}{l}\text { Betonicine, floridoside } \\
\text { and isethionic acid }\end{array}$ & Compete with AHL signals & Kim et al. (2007) \\
\hline Delisea pulchra & Halogenated furanones & $\begin{array}{l}\text { Mimic AHL signals, } \\
\text { inhibit gene expression }\end{array}$ & Manefield et al. (1999) \\
\hline Galaxauraceae & Not identified (algal extract) & AHL inhibitors & Skindersoe et al. (2008) \\
\hline Laurencia sp. & Not identified (algal extract) & AHL inhibitors & Skindersoe et al. (2008) \\
\hline Unidentified red algae & Not identified (algal extract) & AHL inhibitors & Skindersoe et al. (2008) \\
\hline
\end{tabular}


thetic origin of molecules isolated from macroalgae need to be addressed. In several cases, it has already been proven that metabolites initially assigned to the basibionts are in fact of microbial origin (Jensen \& Fenical 1994, Schmidt 2005, Dobretsov et al. 2006a, König et al. 2006, Egan et al. 2008, Jones et al. 2008, Lane \& Kubanek 2008, Rungprom et al. 2008). Chlorophyll $d$, for example, is not a constituent of red algae as was described for more than $60 \mathrm{yr}$. In fact, it does not even occur in eukaryotes at all, but is produced by the cyanobacterium Acaryochloris spp. (Murakami et al. 2004, Larkum \& Kühl 2005; Table 4). Further studies like this including labelling experiments and genetic studies of biosynthetic genes will reveal the producing part of the association for other macroalga-epibiontsystems.

\section{APPLIED ASPECTS OF BACTERIAL-MACROALGAL INTERACTIONS}

The development and expansion of macroalgal farming stresses the need for understanding the relationship between macroalgae and symbiotic as well as pathogenic microorganisms in both wild and cultivated populations (Correa 1996). The extensive farming of brown, red and green macroalgae in Asia has shown that all are susceptible to disease (Craigie \& Correa 1996). In aquaculture, secondary bacterial infections contribute to disintegration of the infected tissue, finally leading to thallus rupture, breaking-off of macroalgae from culture lines and massive biomass loss (Vairappan et al. 2001a, 2008). Infectious diseases in macroalgae might be highly destructive as in the case of the green spot rot of Undaria spp. and the white rot in Nereocystis spp. (Lavilla-Pitogo 1992, Correa et al. 1993, Park et al. 2006, and references therein). Red rot disease is caused by the fungal pathogen Phytium porphyrae affecting different Porphyra species, one of the most popular edible and extensively cultivated macroalga, especially in Asia. In Japan, the disease causes losses of about 40 to 60 million US\$ every year (Woo et al. 2002). Despite some knowledge of the pathogens and diagnosis of the diseases, little is known concerning the ecology of microbial pathogens of these macroalgae (Andrews 1976, Jaffray \& Coyne 1996, Correa 1997; Table 3). The growing use of macroalgae and their products enforces the need to understand the nature and severity of diseases that can be anticipated in macroalgal mariculture (Apt 1984). The development of appropriate strategies will provide adequate and improved protection of the macroalgae in order to lower commercial risks (Park et al. 2006). For this purpose, pathogens of macroalgae have to be identified and characterized at the species level and strategies have to be developed to prevent infection of macroalgae by such pathogens.

On the other hand, there is an increasing interest in algae-associated microorganisms as a source for natural bioactive substances (Egan et al. 2008). Algaassociated bacteria represent an important potential source of new substances and have been identified as a promising source of new bioactive and antimicrobial metabolites (Yan et al. 2002, Penesyan et al. 2009). Novel infectious diseases of humans, reemerging diseases, and the widespread distribution of multidrugresistant pathogenic bacteria clearly indicate a strong need to develop new antibiotics (Fenical 1993, Skindersoe et al. 2008). Table 4 provides a comprehensive overview of compounds produced by macroalgaassociated bacteria. Most of these compounds including peptides or diketopiperazines were produced by members of Pseudoalteromonas.

\section{CONCLUSIONS AND PERSPECTIVES}

Epibiotic bacteria are fast colonizers, highly adaptative and capable of rapid metabolization of algal exudates, and therefore play a key role in the colonization and biofouling process on macroalgae (Lachnit et al. 2009). Chemical interactions between different species of bacteria affect the production and secretion of secondary metabolites in these microorganisms (Jensen \& Fenical 1994, Burgess et al. 1999, Rao et al. 2005). The competition for space between epibiotic bacteria based on compounds may provide an antifouling protection to the algal basibiont (Armstrong et al. 2001, Rungprom et al. 2008). Since symbiotic bacteria, pathogens, and foulers first select, then settle, and finally attach to the host, macroalgae may prevent damage by also producing secondary metabolites that inhibit one or all of these steps. Such metabolites represent the chemical first line of defense against microbial challenge. If the bacterial attachment is not stopped successfully, other secondary metabolites may inhibit the growth, survival, virulence, or reproduction of possibly invading organisms. These second line compounds may be produced by the macroalgae or by epiphytic and endophytic microbes associated with them (Egan et al. 2000, Than et al. 2004, Rao et al. 2007, Lane \& Kubanek 2008). A mutualistic relationship can be postulated in which the bacterial community protects the host from biofouling, while the host surface may provide nutrients and physical protection to the bacteria (Penesyan et al. 2010). The selection of these 'symbiotic' microorganisms might also be chemically mediated (Lachnit et al. 2010). However, after more than $20 \mathrm{yr}$ of research on this topic, there is still no experimental evidence demonstrating if or how host organ- 
isms selectively attract and harbor such epibionts (Harder 2009). There is an enormous variety of different metabolites as possible mediators of interspecies interactions in the algal biosphere, including products of the algal host, pathogens, foulers, and symbionts. Although bacterial secondary metabolites are likely to participate in such interactions, little is known about the role of bacterial secondary metabolites in mediating such ecological interactions (Maximilien et al. 1998, Meusnier et al. 2001). An interesting aspect is the chemical interaction between hosts and their symbionts, the details, including host specificity, nutrients and metabolite exchange, and cell-cell communication have to be revealed by further studies.

In order to develop a better understanding of chemically mediated communication on and with the alga, it is important to detect the allocation of secondary metabolites within the host tissues (Dworjanyn et al. 1999, 2006, Sudatti et al. 2008). For such investigations, it is essential to measure the in situ concentrations and the methods of release of putative deterrents (Krug et al. 2006, Paradas et al. 2010). Only a few analyses have attempted to measure the concentration of these compounds in seawater and host tissues (de Nys et al. 1998, Maximilien et al. 1998, Dworjanyn et al. 1999, Manefield et al. 1999, Kubanek et al. 2003, Paul et al. 2006, Sudatti et al. 2006). The recent improvement of techniques for detecting natural products on tissue surfaces, such as desorption electrospray ionization mass spectrometry (DESI-MS), will provide new sensitive and effective approaches to resolve localization and origin of these compounds (Lane et al. 2009, Nyadong et al. 2009). Improved chemical and molecular biological methods coupled with ecologically relevant bioassays are likely to lead to new discoveries (Hay 2009) and to a better understanding of the development of complex chemical defense mechanisms against microbial threats. The results will enforce our knowledge of distinct functions of bacteria in various kinds of interactions between macroalgae and bacteria, as well as within the bacterial community.

In addition to the chemical point of view, we also need more detailed studies of the bacterial communities and their development, using new molecular approaches. Until now, most investigations have focussed on 1 or 2 different techniques to describe communities. From our point of view, a synopsis between culture-dependent and -independent methods is needed. Various authors have already shown that the diversity of a given bacterial community cannot be described by applying either genetic or culture-based methods (Jensen et al. 1996, Tujula et al. 2006, Longford et al. 2007, Penesyan et al. 2009). Since most studies presented qualitative information but did not analyze abundances and ratios that occur in situ, the application of quantitative or semi-quantitative methods is required, such as cloning techniques, cytogenetic fluorescence in situ hybridization (CFISH), real time quantitative PCR (qPCR), denaturing gradient gel electrophoresis (DGGE), and terminal restriction fragment length polymorphism of DNA (T-RLFP), as well as metagenome studies. The genes used for these investigations should comprise phylogenetic markers as well as functional genes in order to obtain insight into biosynthetic pathways and their regulation, in particular of those used in the production of the interacting small molecules. Community description should be extended by studying the geographic distribution among different host populations with respect to the associated bacterial communities, which are necessary to clarify eventual effects (Wright et al. 2000).

To sum up, there is a strong need to integrate aspects of ecology, cell biology, and chemistry in further studies (Steinberg \& de Nys 2002) in order to understand the production and the distribution of the bioactive molecules in situ as well as their ecological impact on the macroalgal-bacterial interactions.

Acknowledgements. This study was financed by the DAAD (German Academical Exchange Service), the CONICYT (Comité Nacional de Ciencia y Tecnología, Chile), and the Ministry of Science, Economic Affairs and Transport of the State of Schleswig-Holstein (Germany) within the frame of 'Future Program of Economy', which is supported by the European fund for regional development (EFRE).

\section{LITERATURE CITED}

Adhikari U, Mateu CG, Chattopadhyay K, Pujol CA, Damonte EB, Ray B (2006) Structure and antiviral activity of sulfated fucans from Stoechospermum marginatum. Phytochemistry $67: 2474-2482$

Aeby GS (2007) First record of coralline lethal orange disease (CLOD) in the Northwestern Hawaiian Islands. Coral Reefs 26:385

- Akagawa-Matsushita M, Matsuo M, Koga Y, Yamasat K (1992) Alteromonas atlantica sp. nov. and Alteromonas carrageenovora sp. nov., bacteria that decompose algal polysaccharides. Int J Syst Bacteriol 42:621-627

Ali MS, Saleem M, Yamdagni R, Ali MA (2002) Steroid and antibacterial steroidal glycosides from marine green alga Codium iyengarii Borgesen. Nat Prod Lett 16:407-413

> Allouch J, Jam M, Helbert W, Barbeyron T, Kloareg B, Henrissat B, Czjzek M (2003) The three-dimensional structures of two beta-agarases. J Biol Chem 278:47171-47180

Amico V, Cunsolo F, Neri P, Piattelli M, Ruberto G (1988) Antimicrobial tetraprenyltoluquinol derivatives from Cystoseira spinosa var. squarrosa. Phytochemistry 27: $1327-1331$

Amsler CD (ed) (2008) Algal chemical ecology. Springer, Berlin

> Amsler CD, Fairhead VA (2005) Defensive and sensory chemical ecology of brown algae. Adv Bot Res 43:1-91

> An QD, Zhang GL, Wu HT, Zhang ZC and others (2008) Properties of an alginate-degrading Flavobacterium sp. strain 
LXA isolated from rotting algae from coastal China. Can J Microbiol 54:314-320

An QD, Zhang GL, Wu HT, Zhang ZC and others (2009) Alginate-deriving oligosaccharide production by alginase from newly isolated Flavobacterium sp. LXA and its potential application in protection against pathogens. J Appl Microbiol 106:161-170

Ando Y, Inoue K (1961) Decomposition of alginic acid by microorganisms. IV. On the Vibrio-type bacteria, newly isolated from the decaying Laminaria. Nippon Suisan Gakkaishi 27:337-341

Andrews JH (1976) The pathology of marine algae. Biol Rev Camb Philos Soc 51:211-253

- Apt K (1984) Effect of the symbiotic red alga Hypneocolax stellaris on its host Hypnea musciformis (Hypneaceae, Gigartinales). J Phycol 20:148-150

Apt K (1988) Galls and tumor-like growths on marine macroalgae. Dis Aquat Org 4:211-217

Apt K, Gibor A (1989) Development and induction of bacteriaassociated galls on Prionitis lanceolata (Rhodophyta). Dis Aquat Org 6:151-156

Ar Gall EA, Cornec L, Deslandes E (2008) Oligocarrageenans and tissue-dependant oxidative burst in Solieria chordalis (Rhodophyceae, Gigartinales). Phycological Res 56:7-12

Ara J (2001) Studies on bioactivity in some seaweeds from Karachi coast. $\mathrm{PhD}$ thesis, University of Karachi, Pakistan

Araki T, Tamaru Y, Morishita T (1992) ß-1,4-mannanases from marine bacteria, Vibrio spp. MA-129 and MA-138. J Gen Appl Microbiol 38:343-351

- Ariosa Y, Quesada A, Aburto J, Carrasco D, Carreres R, Leganes F, Fernandez-Valiente E (2004) Epiphytic cyanobacteria on Chara vulgaris are the main contributors to $\mathrm{N}_{2}$ fixation in rice fields. Appl Environ Microbiol 70: 5391-5397

Armstrong E, Yan L, Boyd KG, Wright PC, Burgess JG (2001) The symbiotic role of marine microbes on living surfaces. Hydrobiologia 461:37-40

Ashen JB, Goff LJ (1998) Galls on the marine red alga Prionitis lanceolata (Halymeniaceae): specific induction and subsequent development of an algal-bacterial symbiosis. Am J Bot 85:1710-1721

Ashen JB, Goff LJ (2000) Molecular and ecological evidence for species coevolution in a group of marine algal-bacterial symbioses. Appl Environ Microbiol 66:3024-3030

- Ashen JB, Cohen JD, Goff LJ (1999) GC-SIM-MS detection and quantification of free indole-3-acetic acid in bacterial galls on the marine alga Prionitis lanceolata (Rhodophyta). J Phycol 35:493-500

Bae SS, Kwon KK, Yang SH, Lee HS, Kim SJ, Lee JH (2007) Flagellimonas eckloniae gen. nov., sp. nov., a mesophilic marine bacterium of the family Flavobacteriaceae, isolated from the rhizosphere of Ecklonia kurome. Int J Syst Evol Microbiol 57:1050-1054

Bakunina IY, Shevchenko LS, Nedashkovskaya OI, Shevchenko NM, Alekseeva SA, Mikhailov VV, Zvyagintseva TN (2000) Screening of marine bacteria for fucoidanases. Microbiology (NY) 69:303-308

Bakunina IY, Nedashkovshaia OI, Alekseeva SA, Ivanova EP and others (2002) Degradation of fucoidan by the marine proteobacterium Pseudoalteromonas citrea. Microbiology (NY) 71:41-47

Ballantine DL, Gerwick WH, Velez SM, Alexander E, Guevara P (1987) Antibiotic activity of lipid-soluble extracts from Caribbean marine algae. Hydrobiologia 151-152: 463-469

Bansemir A, Just N, Michalik M, Lindequist U, Lalk M (2004) Extracts and sesquiterpene derivatives from the red alga
Laurencia chondrioides with antibacterial activity against fish and human pathogenic bacteria. Chem Biodivers 1: 463-467

Barbeyron T, Berger Y (1989) Commensal bacteria living with two multicellular marine algae: Antithamnion plumula (Ellis) Thuret and Cladophora rupestris (L.) Kützing (Linne), Kützing. Phenotypic characterization. Cah Biol Mar 30:361-374

Barbeyron T, Gerard A, Potin P, Henrissat B, Kloareg B (1998) The kappa-carrageenase of the marine bacterium Cytophaga drobachiensis. Structural and phylogenetic relationships within family-16 glycoside hydrolases. Mol Biol Evol 15:528-537

Barbeyron T, Michel G, Potin P, Henrissat B, Kloareg B (2000) -Carrageenases constitute a novel family of glycoside hydrolases, unrelated to that of $\kappa$-carrageenases. J Biol Chem 275:35499-35505

Barbeyron T, L'Haridon S, Corre E, Kloareg B, Potin P (2001) Zobellia galactanovorans gen. nov., sp. nov., a marine species of Flavobacteriaceae isolated from a red alga, and classification of three novel Zobellia species [Cytophaga] uliginosa (ZoBell and Upham 1944) Reichenbach 1989 as Zobellia uliginosa gen. nov., comb. nov. Int J Syst Evol Microbiol 51:985-997

Barbeyron T, L'Haridon S, Michel G, Czjzek M (2008) Mariniflexile fucanivorans sp. nov., a marine member of the Flavobacteriaceae that degrades sulphated fucans from brown algae. Int J Syst Evol Microbiol 58:2107-2113

> Barreto M, Meyer JJM (2006) Isolation and antimicrobial activity of a lanosol derivative from Osmundaria serrata (Rhodophyta) and a visual exploration of its biofilm covering. S Afr J Bot 72:521-528

Beleneva IA, Zhukova NV (2006) Bacterial communities of some brown and red algae from Peter the Great Bay, the Sea of Japan. Microbiology (NY) 75:410-419

Bell W, Mitchell R (1972) Chemotactic and growth responses of marine bacteria to algal extracellular products. Biol Bull 143:265-277

> Bengtsson M, Sjøtun K, Øvreås L (2010) Seasonal dynamics of bacterial biofilms on kelp (Laminaria hyperborea). Aquat Microb Ecol 60:71-83

Bennamara A, Abourriche A, Berrada M, Charrouf M, Chaib N, Boudouma M, Garneau FX (1999) Methoxybifurcarenone: an antifungal and antibacterial meroditerpenoid from the brown alga Cystoseira tamariscifolia. Phytochemistry 52:37-40

Berland BR, Bonin DJ, Maestrini SY (1972) Are some bacteria toxic for marine algae? Mar Biol 12:189-193

Berry A, Janssens D, Hümbelin M, Jore JPM and others (2003) Paracoccus zeaxanthinifaciens sp. nov., a zeaxanthin-producing bacterium. Int J Syst Evol Microbiol 53: 231-238

> Bhadury P, Wright PC (2004) Exploitation of marine algae: biogenic compounds for potential antifouling applications. Planta 219:561-578

Bhakuni DS, Rawat DS (2005) Bioactive marine natural products. Springer, New York, NY

Bhakuni DS, Silva M (1974) Biodynamic substances from marine flora. Bot Mar 17:40-51

Bhattarai HD, Ganti VS, Paudel B, Lee YK, Lee HK, Hong YK, Shin HW (2007) Isolation of antifouling compounds from the marine bacterium, Shewanella oneidensis SCH0402. World J Microbiol Biotechnol 23:243-249

> Bianco EM, Rogers R, Texeira VL, Pereira RC (2009) Antifoulant diterpenes produced by the brown seaweed Canistrocarpus cervicornis. J Appl Phycol 21:341-346

Bland JA, Brock TD (1973) The marine bacterium Leucothrix 
mucor as an algal epiphyte. Mar Biol 23:283-292

Bode HB, Bethe B, Höfs R, Zeeck A (2002) Big effects from small changes: possible ways to explore nature's chemical diversity. ChemBioChem 3:619-627

Bolinches J, Lemos ML, Barja JL (1988) Population dynamics of heterotrophic bacterial communities associated with Fucus vesiculosus and Ulva rigida in an estuary. Microb Ecol 15:345-357

Booth WE, Hoppe HG (1985) Epiphytic bacterial activity on different macroalgal species determined by tritiated thymidine incorporation. Bot Mar 28:47-56

Borchardt SA, Allain EJ, Michels JJ, Stearns GW, Kelly RF, McCoy WF (2001) Reaction of acylated homoserine lactone bacterial signaling molecules with oxidized halogen antimicrobials. Appl Environ Microbiol 67:3174-3179

> Bouarab K, Potin P, Correa J, Kloareg B (1999) Sulfated oligosaccharides mediate the interaction between a marine red alga and its green algal pathogenic endophyte. Plant Cell 11:1635-1650

Bouarab K, Potin P, Weinberger F, Correa J, Kloareg B (2001) The Chondrus crispus-Acrochaete operculata hostpathogen association, a novel model in glycobiology and applied phycopathology. J Appl Phycol 13:185-193

Bouarab K, Adas F, Gaquerel E, Kloareg B, Salaün JP, Potin P (2004) The innate immunity of a marine red alga involves oxylipins from both the eicosanoid and octadecanoid pathways. Plant Physiol 135:1838-1848

Bouvy M, Le Romancer M, Delille D (1986) Significance of microheterotrophs in relation to the degradation process of subantarctic kelp beds (Macrocystis pyrifera). Polar Biol 5:249-253

> Boyd KG, Mearns-Spragg A, Burgess JG (1999a) Screening of marine bacteria for the production of microbial repellents using a spectrophotometric assay. Mar Biotechnol 1: 359-363

Boyd KG, Adams DR, Burgess JG (1999b) Antibacterial and repellent activities of marine bacteria associated with algal surfaces. Biofouling 14:227-236

> Boyen C, Bertheau Y, Barbeyron T, Kloareg B (1990) Preparation of guluronate lyase from Pseudomonas alginovora for protoplast isolation in Laminaria. Enzyme Microb Technol 12:885-890

Brock TD, Clyne J (1984) Significance of algal excretory products for growth of epilimnetic bacteria. Appl Environ Microbiol 47:731-734

Brown BJ, Preston JF, Ingram L (1991) Cloning of alginate lyase gene $(a l x M)$ and expression in Escherichia coli. Appl Environ Microbiol 57:1870-1872

Burgess JG, Jordan EM, Bregu M, Mearns-Spragg A, Boyd KG (1999) Microbial antagonism: a neglected avenue of natural products research. J Biotechnol 70:27-32

Burgess JG, Boyd KG, Armstrong E, Jiang Z and others (2003) The development of a marine natural product-based antifouling paint. Biofouling 19:197-205

Burke C, Kjelleberg S, Thomas T (2009) Selective extraction of bacterial DNA from the surfaces of macroalgae. Appl Environ Microbiol 75:252-256

Burr FA, West JA (1970) Light and electron microscope observations on the vegetative and reproductive structures of Bryopsis hypnoides. Phycologia 10:125-134

Buschmann A, Correa JA, Beltran J, Retamales CA (1997) Determinants of disease expression and survival of infected individual fronds in wild populations of Mazzaella laminarioides (Rhodophyta) in central and southern Chile. Mar Ecol Prog Ser 154:269-280

> Byappanahalli MN, Shively DA, Nevers MB, Sadowsky MJ, Whitman RL (2003) Growth and survival of Escherichia coli and enterococci populations in the macro-alga Cladophora (Chlorophyta). FEMS Microbiol Ecol 46: 203-211

> Carlson DJ, Lubchenco J, Sparrow MA, Trowbridge CD (1989) Fine-scale variability of lanosol and its disulfate ester in the temperate red alga Neorhodomela larix. J Chem Ecol 15:1321-1333

Carpenter EJ (1972) Nitrogen fixation by a bluegreen epiphyte on pelagic Sargassum. Science 178:1207-1208

Carpenter EJ, Cox JL (1974) Production of pelagic Sargassum and a blue-green epiphyte in the western Sargasso Sea. Limnol Oceanogr 19:429-436

> Chakraborty K, Lipton AP, Raj RP, Vijayan KK (2010) Antibacterial labdane diterpenoids of Ulva fasciata Delile from southwestern coast of the Indian Peninsula. Food Chem 119:1399-1408

Chattopadhyay K, Mateu CG, Mandal P, Pujol CA, Damonte EB, Ray B (2007) Galactan sulfate of Grateloupia indica: isolation, structural features and antiviral activity. Phytochemistry 68:1428-1435

Chesters CGC, Apinis A, Turner M (1956) Studies of the decomposition of seaweeds and seaweed products by microorganisms. Proc Linn Soc Lond 166:87-97

Chisholm JRM, Dauga C, Ageron E, Grimont PAD (1996) Roots in mixotrophic algae. Nature 381:382

Cole JJ (1982) Interactions between bacteria and algae in aquatic ecosystems. Annu Rev Ecol Syst 13:291-314

Colin S, Deniaud E, Jam M, Descamps V and others (2006) Cloning and biochemical characterization of the fucanase FcnA: definition of a novel glycoside hydrolase family specific for sulfated fucans. Glycobiology 16:1021-1032

Colombo PM (1978) Occurrence of endophytic bacteria in Siphonous algae. Phycologia 17:148-151

Colon M, Guevara P, Gerwick WH, Ballantine D (1987) 5'hydroxyisoavrainvilleol, a new diphenylmethane derivative from the tropical green alga Avrainvillea nigricans. J Nat Prod 50:368-374

> Corre A, Prieur D (1990) Density and morphology of epiphyte bacteria on the kelp Laminaria digitata. Bot Mar 33: $515-523$

> Correa JA (1996) Diseases in seaweeds: an introduction. Hydrobiologia 326-327:87-88

Correa JA (1997) Infectious diseases of marine algae: current knowledge and approaches. In: Round FE, Chapman DJ (eds) Progress in phycological research, Vol 12. Biopress, Bristol, p 140-180

Correa JA, McLachlan JL (1994) Endophytic algae of Chondrus crispus Stackh. (Rhodophyta). V. Fine structure of the infection by Acrochaete operculata (Chlorophyta). Eur J Phycol 29:33-47

Correa JA, Sánchez PA (1996) Ecological aspects of algal infectious diseases. Hydrobiologia 326-327:89-95

Correa JA, Flores V, Sánchez P (1993) Deformative disease in Iridaea laminarioides (Rhodophyta): gall development associated with an endophytic cianobacterium. J Phycol 29:853-860

> Cosse A, Leblanc C, Potin P (2007) Dynamic defense of marine macroalgae against pathogens: from early activated to gene-regulated responses. Adv Bot Res 46: 221-266

Coveney MF, Wetzel RG (1989) Bacterial metabolism of algal extracellular carbon. Hydrobiologia 173:141-149

> Craigie JS, Correa JA, Gordon M (1992) Cuticles from Chondrus crispus. J Phycol 28:777-786

Craigie JS, Correa JA (1996) Etiology of infectious diseases in cultivated Chondrus crispus (Gigartinales, Rhodophyta). Hydrobiologia 326-327:97-104 
Croft MT, Lawrence AD, Raux-Deery E, Warren MJ, Smith AG (2005) Algae acquire vitamin B12 through a symbiotic relationship with bacteria. Nature 438:90-93

Croft MT, Warren MJ, Smith AG (2006) Algae need their vitamins. Eukaryot Cell 5:1175-1183

> Cronin G, Hay ME (1996) Within-plant variation in seaweed chemical defences: optimal defence theory versus the growth-differentiation balance hypothesis. Oecologia 105: 361-368

Cundell AM, Sleeter TD, Mitchell R (1977) Microbial populations associated with the surface of the brown alga Ascophyllum nodosum. Microb Ecol 4:81-91

Da Gama BAP, Pereira RC, Carvalho AGV, Coutinho R, Yoneshigue-Valentin Y (2002) The effects of seaweed secondary metabolites on biofouling. Biofouling 18:13-20

$>$ Davidson IW, Sutherland IW, Lawson CJ (1976) Purification and properties of an alginate lyase from a marine bacterium. Biochem J 159:707-713

> Davies DG, Parsek MR, Pearson JP, Iglewski BH, Costerton JW, Greenberg EP (1998) The involvement of cell-to-cell signals in the development of a bacterial biofilm. Science 280:295-298

Dawes CJ, Lohr CA (1978) Cytoplasmic organization and endosymbiotic bacteria in the growing points of Caulerpa prolifera. Rev Algol 13:309-314

de Nys R, Wright AD, König GM, Sticker O (1993) New halogenated furanones from the marine alga Delisea pulchra. Tetrahedron 49:11213-11220

de Nys R, Dworjanyn SA, Steinberg PD (1998) A new method for determining surface concentrations of marine natural products on seaweeds. Mar Ecol Prog Ser 162:79-87

> De Silva SMS, Gamage KTS, Kumar NS, Balasubramaniam S (1982) Anti-bacterial activity of extracts from the brown seaweed Stoechospermum marginatum. Phytochemistry 21:944-945

Delbridge L, Coulburn J, Fagerber W, Tisa LS (2004) Community profiles of bacterial endosymbionts in four species of Caulerpa. Symbiosis 37:335-344

> Delille D, Perret E (1991) The influence of giant kelp Macrocystis pyrifera on the growth of subantarctic marine bacteria. J Exp Mar Biol Ecol 153:227-239

Descamps V, Colin S, Lahaye M, Jam M and others (2006) Isolation and culture of a marine bacterium degrading the sulfated fucans from marine brown algae. Mar Biotechnol 8:27-39

> Dickschat JS (2010) Quorum sensing and bacterial biofilms. Nat Prod Rep 27:343-369

> Diggle SP, Crusz SA, Cámara M (2007) Quorum sensing. Curr Biol 17:R907-R910

Dimitrieva GY, Dimitriev SM (1996) Symbiotic microflora of the brown algae from the genus Laminaria as a bioindicator of the ecological state of coastal Laminaria biocoenoses. Russ J Mar Biol 22:276-281

> Dimitrieva GY, Crawford RL, Yuksel GU (2006) The nature of plant growth-promoting effects of a pseudoalteromonad associated with the marine algae Laminaria japonica and linked to catalase excretion. J Appl Microbiol 100: 1159-1169

Dobretsov SV (2009) Inhibition and induction of marine biofouling by biofilms. In: Flemming $\mathrm{HC}$, Murthy PS, Venkatesan R, Cooksey K (eds) Marine and industrial biofouling. Springer, Berlin, p 292-313

> Dobretsov SV, Qian PY (2002) Effect of bacteria associated with the green alga Ulva reticulata on marine micro- and macrofouling. Biofouling 18:217-228

> Dobretsov S, Dahms HU, Qian PY (2006a) Inhibition of biofouling by marine microorganisms and their metabolites.
Biofouling 22:43-54

Dobretsov SV, Dahms HU, Harder T, Qian PY (2006b) Allelochemical defense against epibiosis in the macroalga Caulerpa racemosa var. turbinata. Mar Ecol Prog Ser 318:165-175

Dobretsov S, Teplitski M, Paul V (2009) Mini-review: quorum sensing in the marine environment and its relationship to biofouling. Biofouling 25:413-427

$>$ Dring MJ (2005) Stress resistance and disease resistance in seaweeds: the role of reactive oxygen metabolism. Adv Bot Res 43:175-207

Dromgoole FI, Silvester WB, Hicks BJ (1978) Nitrogenase activity associated with Codium species from New Zealand marine habitats. NZ J Mar Freshw Res 12:17-22

Du ZJ, Lv GQ, Rooney AP, Miao TT, Xu QQ, Chen GJ (in press) Agarivorans gilvus sp. nov. isolated from seaweed. Int J Syst Evol Microbiol. doi:10.1099/ijs.0.019810-0

> Duan D, Xu L, Fei X, Xu H (1995) Marine organisms attached to seaweed surfaces in Jiaozhou Bay, China. World J Microbiol Biotechnol 11:351-352

> Dubber D, Harder T (2008) Extracts of Ceramium rubrum, Mastocarpus stellatus and Laminaria digitata inhibit growth of marine and fish pathogenic bacteria at ecologically realistic concentrations. Aquaculture 274:196-200

> Dworjanyn SA, de Nys R, Steinberg PD (1999) Localization and surface quantification of secondary metabolites in the red alga Delisea pulchra. Mar Biol 133:727-736

> Dworjanyn SA, de Nys R, Steinberg PD (2006) Chemically mediated antifouling in the red alga Delisea pulchra. Mar Ecol Prog Ser 318:153-163

> Egan S, Thomas T, Holmstrom C, Kjelleberg S (2000) Phylogenetic relationship and antifouling activity of bacterial epiphytes from the marine alga Ulva lactuca. Environ Microbiol 2:343-347

Egan S, Holmström C, Kjelleberg S (2001a) Pseudoalteromonas ulvae sp. nov., a bacterium with antifouling activities isolated from the surface of a marine alga. Int J Syst Evol Microbiol 51:1499-1504

> Egan S, James S, Holmström C, Kjelleberg S (2001b) Inhibition of algal spore germination by the marine bacterium Pseudoalteromonas tunicata. FEMS Microbiol Ecol 35: $67-73$

Egan S, Thomas T, Kjelleberg S (2008) Unlocking the diversity and biotechnological potential of marine surface associated microbial communities. Curr Opin Microbiol 11: 219-225

> Engel S, Jensen PR, Fenical W (2002) Chemical ecology of marine microbial defense. J Chem Ecol 28:1971-1985

Engel S, Puglisi MP, Jensen PR, Fenical W (2006) Antimicrobial activities of extracts from tropical Atlantic marine plants against marine pathogens and saprophytes. Mar Biol 149:991-1002

Englebert ET, McDermott C, Kleinheinz GT (2008) Effects of the nuisance algae, Cladophora, on Escherichia coli at recreational beaches in Wisconsin. Sci Total Environ 404: $10-17$

Estevao Belchior E, Gallardo A, Risso S, Fajardo MA (2003) Evaluacion microbiologica del alga comestible Porphyra columbina, Montagne, de la costa patagonica argentina. FABICIB 7:55-64

>tahiri S, Bultel-Ponce V, Caux C, Guyot M (2001) New bromoditerpenes from the red alga Sphaerococcus coronopifolius. J Nat Prod 64:1024-1027

Ezura Y, Yamamoto H, Kimura T (1988) Isolation of a marine bacterium that produces red-spots on the culture bed of makonbu Laminaria japonica cultivation. Nippon Suisan Gakkaishi 54:665-672 
Fenical W (1993) Chemical studies of marine bacteria: developing a new resource. Chem Rev 93:1673-1683

Fenical W, McConnell O (1976) Simple antibiotics from the red seaweed Dasya pedicellata var. stanfordiana. Phytochemistry 15:435-436

Fenical W, Sims JJ, Squatrito D, Wing RM, Radlick P (1973) Zonarol and isozonarol, fungitoxic hydroquinones from the brown seaweed Dictyopteris zonarioides. J Org Chem 38:2383-2386

Fisher MM, Wilcox LW, Graham LE (1998) Molecular characterization of epiphytic bacterial communities on Charophycean green algae. Appl Environ Microbiol 64: 4384-4389

Flament D, Barbeyron T, Jam M, Potin P, Czjzek M, Kloareg B, Michel G (2007) Alpha-agarases define a new family of glycoside hydrolases, distinct from beta-agarase families. Appl Environ Microbiol 73:4691-4694

Franks A, Egan S, Holmström C, James S, Lappin-Scott H, Kjelleberg S (2006) Inhibition of fungal colonization by Pseudoalteromonas tunicata provides a competitive advantage during surface colonization. Appl Environ Microbiol 72:6079-6087

> Freile-Pelegrin Y, Morales JL (2004) Antibacterial activity in marine algae from the coast of Yucatan, Mexico. Bot Mar 47:140-146

Fries L (1975) Some observations on the morphology of Enteromorpha linza (L.) J. Ag. and Enteromorpha compressa (L.) Grev. in axenic culture. Bot Mar 18:251-253

Fu XT, Kim SM (2010) Agarase: review of major sources, categories, purification method, enzyme characteristics and applications. Mar Drugs 8:200-218

> Fudou R, Iizuka T, Yamanaka S (2001) Haliangicin, a novel antifungal metabolite produced by a marine Myxobacterium 1. Fermentation and biological characteristics. J Antibiot (Tokyo) 54:149-152

Fujita Y, Zenitani B, Nakao Y, Matsubara T (1972) Bacteriological studies on diseases of cultured laver. II. Bacteria associated with diseased laver. Bull Jpn Soc Sci Fish 38: 565-569

Fukunaga Y, Kurahashi M, Sakiyama Y, Ohuchi M, Yokota A, Harayama S (2009) Phycisphaera mikurensis gen. nov., sp. nov., isolated from a marine alga, and proposal of Phycisphaeraceae fam. nov., Phycisphaerales ord. nov. and Phycisphaerae classis nov. in the phylum Planctomycetes. J Gen Appl Microbiol 55:267-275

> Furukawa S, Fujikawa T, Koga D, Ide A (1992) Purification and some properties of exo-type fucoidanase from Vibrio sp. N-5. Biosci Biotechnol Biochem 56:1829-1834

Gallardo AA, Risso S, Fajardo MA, Belchior ES (2004) Characterization of microbial population present in the edible seaweed, Monostroma undulatum, Wittrock. Arch Latinoam Nutr 54:337-345

Genilloud O, Pelaez F, Gonzalez I, Diez MT (1994) Diversity of actinomycetes and fungi on seaweeds from the Iberian coasts. Microbiologia SEM 10:413-422

Gerard J, Lloyd R, Barsby T, Haden P, Kelly MT, Andersen RJ (1997) Massetolides A-H, antimycobacterial cyclic depsipeptides produced by two pseudomonads isolated from marine habitats. J Nat Prod 60:223-229

Ghirardelli LA (1998) An endolithic cyanophyte in the cell wall of calcareous algae. Bot Mar 41:367-373

Ghirardelli LA (2002) Endolithic microorganisms in live and dead thalli of coralline red algae (Corallinales, Rhodophyta) in the Northern Adriatic Sea. Acta Geol Hisp 37: 53-60

> Givskov M, de Nys R, Manefield M, Gram L and others (1996) Eukaryotic interference with homoserine lactone-medi- ated prokaryotic signalling. J Bacteriol 178:6618-6622

Gram L, de Nys R, Maximilien R, Givskov M, Steinberg P, Kjelleberg $S$ (1996) Inhibitory effects of secondary metabolites from the red alga Delisea pulchra on swarming motility of Proteus mirabilis. Appl Environ Microbiol 62:4284-4287

Hanzawa N, Nakanishi K, Nishijima M, Saga N (1998) 16S rDNA-based phylogenetic analysis of marine Flavobacteria that induce algal morphogenesis. J Mar Biotechnol 6: $80-82$

Harder T (2009) Marine epibiosis: concepts, ecological consequences and host defence. In: Flemming HC, Murthy PS, Venkatesan R, Cooksey K (eds) Marine and industrial biofouling. Springer, Berlin, p 219-231

Harder T, Lam C, Qian PY (2002) Induction of larval settlement in the polychaete Hydroides elegans by marine biofilms: an investigation of monospecific diatom films as settlement cues. Mar Ecol Prog Ser 229:105-112

Harder T, Dobretsov S, Qian PY (2004) Waterborne polar macromolecules act as algal antifoulants in the seeweed Ulva reticulata. Mar Ecol Prog Ser 274:131-141

- Hay M (1996) Marine chemical ecology: what's known and what's next? J Exp Mar Biol Ecol 200:103-134

Hay ME (2009) Marine chemical ecology: chemical signals and cues structure marine populations, communities, and ecosystems. Annu Rev Mar Sci 1:193-212

Head WD, Carpenter EJ (1975) Nitrogen fixation associated with the marine macroalga Codium fragile. Limnol Oceanogr 20:815-823

> Hellio C, De La Broise D, Dufosse L, Le Gal Y, Bourgougnon $N$ (2001) Inhibition of marine bacteria by extracts of macroalgae: potential use for environmentally friendly antifouling paints. Mar Environ Res 52:231-247

$>$ Hellio C, Berge JP, Beaupoil C, Le Gal Y, Bourgougnon N (2002) Screening of marine algal extracts for anti-settlement activities against microalgae and macroalgae. Biofouling 18:205-215

Hellio C, Marechal JP, Véron B, Bremer AG, Clare AS, Le Gal $Y$ (2004) Seasonal variation of antifouling activities of marine algae from the Brittany coast (France). Mar Biotechnol 6:67-82

Hempel M, Blume M, Blindow I, Gross EM (2008) Epiphytic bacterial community composition on two common submerged macrophytes in brackish water and freshwater. BMC Microbiol 8:58

Holmström C, Kjelleberg S (1999) Marine Pseudoalteromonas species are associated with higher organisms and produce biologically active extracellular agents. FEMS Microbiol Ecol 30:285-293

> Holmström C, Rittschof D, Kjelleberg S (1992) Inhibition of settlement by larvae of Balanus amphitrite and Cliona intestinalis by surface colonizing marine bacterium. Appl Environ Microbiol 58:2111-2115

Holmström C, James S, Neilan BA, White DC, Kjelleberg S (1998) Pseudoalteromonas tunicata sp. now, a bacterium that produces antifouling agents. Int J Syst Bacteriol 48: 1205-1212

Holmström C, Egan S, Franks A, McCloy S, Kjelleberg S (2002) Antifouling activities expressed by marine surface associated Pseudoalteromonas species. FEMS Microbiol Ecol 41:47-58

Honkanen T, Jormalainen V (2005) Genotypic variation in tolerance and resistance to fouling in the brown alga Fucus vesiculosus. Oecologia 144:196-205

Hoppe HA, Levring T, Tanaka Y (eds) (1979) Marine algae in pharmaceutical science. Walter de Gruyter, Berlin

Hornsey IS, Hide D (1976a) The production of antimicrobial 
compounds by British marine algae II. Seasonal variation in production of antibiotics. Eur J Phycol 11:63-67

Hornsey IS, Hide D (1976b) The production of antimicrobial compounds by British marine algae III. Distribution of antimicrobial activity within the algal thallus. Eur J Phycol 11:175-181

> Huggett MJ, Williamson JE, de Nys R, Kjelleberg S, Steinberg PD (2006) Larval settlement of the common Australian sea urchin Heliocidaris erythrogramma in response to bacteria from the surface of coralline algae. Oecologia 149: 604-619

- Imamura N, Nishijima M, Takadera T, Adachi K (1997) New anticancer antibiotics pelagiomicins, produced by a new marine bacterium Pelagiobacter variabilis. J Antibiot (Tokyo) 50:8-12

Isnansetyo A, Horikawa M, Kamei Y (2001) In vitro antimethicillin-resistant Staphylococcus aureus activity of 2,4diacetylphloroglucinol produced by Pseudomonas sp. AMSN isolated from a marine alga. J Antimicrob Chemother 47:719-730

- Ivanova EP, Nedashkovskaya OI, Chun J, Lysenko AM and others (2001) Arenibacter gen. nov., new genus of the family Flavobacteriaceae and description of a new species, Arenibacter latericius sp. nov. Int J Syst Evol Microbiol 51:1987-1995

Ivanova EP, Bakunina IY, Sawabe T, Hayashi K and others (2002a) Two species of culturable bacteria associated with degradation of brown algae Fucus evanescens. Microb Ecol 43:242-249

- Ivanova EP, Sawabe T, Alexeeva YV, Lysenko MA and others (2002b) Pseudoalteromonas issachenkonii sp. nov., a bacterium that degrades the thallus of the brown alga Fucus evanescens. Int J Syst Evol Microbiol 52:229-234

Ivanova EP, Alexeeva YA, Zhukova NV, Gorshkova NM and others (2004a) Bacillus algicola sp. nov., a novel filamentous organism isolated from brown alga Fucus evanescens. Syst Appl Microbiol 27:301-307

Ivanova EP, Christen R, Alexeeva YV, Zhukova NV and others (2004b) Brevibacterium celere sp. nov., isolated from degraded thallus of a brown alga. Int J Syst Evol Microbiol 54:2107-2111

Ivanova EP, Alexeeva YV, Flavier S, Wright JP and others (2004c) Formosa algae gen. nov., sp. nov., a novel member of the family Flavobacteriaceae. Int J Syst Evol Microbiol 54:705-711

> Ivanova EP, Christen R, Sawabe T, Alexeeva YV, Lysenko AM, Chelomin VP, Mikhailov VV (2005) Presence of ecophysiologically diverse populations within Cobetia marina strains isolated from marine invertebrate, algae and the environments. Microbes Environ 20:200-207

- Jaffray AE, Coyne VE (1996) Development of an in situ assay to detect bacterial pathogens of the red alga Gracilaria gracilis (Stackhouse) Steentoft, Irvine et Farnham. J Appl Phycol 8:409-414

> Jam M, Flament D, Allouch J, Potin P and others (2005) The endo-beta-agarases AgaA and AgaB from the marine bacterium Zobellia galactanivorans: two paralogue enzymes with different molecular organizations and catalytic behaviours. Biochem J 385:703-713

Jamal MT, Morris PC, Hansen R, Jamieson DJ, Burgess JG, Austin B (2006) Recovery and characterization of a 30.7$\mathrm{kDa}$ protein from Bacillus licheniformis associated with inhibitory activity against methicillin-resistant Staphylococcus aureus, vancomycin-resistant Enterococci, and Listeria monocytogenes. Mar Biotechnol 8:587-592

> James SG, Holmström C, Kjelleberg S (1996) Purification and characterization of a novel anti-bacterial protein from the marine bacterium D2. Appl Environ Microbiol 62: 2783-2788

Jensen PR, Fenical W (1994) Strategies for the discovery of secondary metabolites from marine bacteria: ecological perspectives. Annu Rev Microbiol 48:559-584

> Jensen PR, Kauffman CA, Fenical W (1996) High recovery of culturable bacteria from the surfaces of marine algae. Mar Biol 126:1-7

Jiang J, Ma Y, Zhang Z, Xu H (1997) The histopathological study on 'green decay diseases' of Undaria pinnatifida in Dalian. J Dalian Fish Univ 12:7-12

Jiang Z, Mearns-Spragg A, Adams DR, Wright PC, Burgess JG (2001) Two diketopiperazines and one halogenated phenol from cultures of the marine bacterium, Pseudoalteromonas luteoviolacea. Nat Prod Lett 14:435-440

> Jiang RW, Lane AL, Mylacraine L, Hardcastle KI and others (2008) Structures and absolute configurations of sulfate conjugated triterpenoids including an antifungal chemical defense of the marine green alga Tydemania expeditionis. J Nat Prod 71:1616-1619

Johansen JE, Nielsen P, Sjøholm C (1999) Description of Cellulophaga baltica gen. nov., sp. nov. and Cellulophaga fucicola gen. nov., sp. nov. and reclassification of [Cytophaga] Iytica to Cellulophaga lytica gen. nov., comb. nov. Int J Syst Bacteriol 49:1231-1240

Johnson PW, Sieburth JM, Sastry A, Arnold CR, Doty MS (1971) Leucothrix mucor infestation of benthic crustacea, fish eggs, and tropical algae. Limnol Oceanogr 16: 962-969

Johnson CR, Muir DG, Reysenbach AL (1991) Characteristic bacteria associated with surfaces of coralline algae: a hypothesis for bacterial induction of marine invertebrate larvae. Mar Ecol Prog Ser 74:281-294

Joint I, Tait K, Callow ME, Callow JA, Milton D, Williams P, Camara M (2002) Cell-to-cell communication across the prokaryote-eukaryote boundary. Science 298:1207

Joint I, Tait K, Wheeler G (2007) Cross-kingdom signalling: exploitation of bacterial quorum sensing molecules by the green seaweed Ulva. Philos Trans R Soc Lond B 362: 1223-1233

> Jones GEB, Stanley CJ, Pinruan U (2008) Marine endophyte sources of new chemical natural products: a review. Bot Mar 51:163-170

Jonnadula R, Verma P, Shouche YS, Ghadi SC (2009) Characterization of Microbulbifer strain CMC-5, a new biochemical variant of Microbulbifer elongatus type strain DSM6810(T) isolated from decomposing seaweeds. Curr Microbiol 59:600-607

Kalinovskaya NI, Ivanova EP, Alexeeva YV, Gorshkova NM, Kuznetsova TA, Dmitrenok AS, Nicolau DV (2004) Lowmolecular-weight, biologically active compounds from marine Pseudoalteromonas species. Curr Microbiol 48: 441-446

> Kanagasabhapathy M, Sasaki H, Haldar S, Yamasaki S, Nagata $S$ (2006) Antibacterial activities of marine epibiotic bacteria isolated from brown algae of Japan. Ann Microbiol 56:167-173

Kanagasabhapathy M, Sasaki H, Nagata S (2008) Phylogenetic identification of epibiotic bacteria possessing antimicrobial activities isolated from red algal species of Japan. World J Microbiol Biotechnol 24:2315-2321

Kanagasabhapathy M, Yamazaki G, Ishida A, Sasaki H, Nagata S (2009) Presence of quorum-sensing inhibitorlike compounds from bacteria isolated from the brown alga Colpomenia sinuosa. Lett Appl Microbiol 49:573-579

Kang HS, Lee SD (2010) Mesonia phycicola sp. nov., isolated from seaweed, and emended description of the genus 
Mesonia Nedashkovskaya et al. 2003 emend. Nedashkovskaya et al. 2006. Int J Syst Evol Microbiol 60:591-594 Kang HS, Yang HL, Lee SD (2009) Nitratireductor kimnyeongensis sp. nov., isolated from seaweed. Int J Syst Evol Microbiol 59:1036-1039

Katsuta A, Adachi K, Matsuda S, Shizuri Y, Kasai H (2005) Ferrimonas marina sp. nov. Int J Syst Evol Microbiol 55: 1851-1855

Khailov KM, Burlakova ZP (1969) Release of dissolved organic matter by marine seaweeds and distribution of their total organic production to inshore communities. Limnol Oceanogr 14:521-527

Khambhaty Y, Mody K, Jha B (2007) Purification and characterization of $\kappa$-carrageenase from a novel $\gamma$-Proteobacterium, Pseudomonas elongata (MTCC 5261) syn. Microbulbifer elongates comb. nov. Biotechnol Bioprocess Eng 12:668-675

Kim JS, Kim YH, Seo YW, Park S (2007) Quorum sensing inhibitors from the red alga, Ahnfeltiopsis flabelliformis. Biotechnol Bioprocess Eng 12:308-311

Kim DE, Lee EY, Kim HS (2009) Cloning and characterization of alginate lyase from a marine bacterium Streptomyces sp. ALG-5. Mar Biotechnol 11:10-16

Kim WJ, Kim SM, Lee YH, Kim HG and others (2008) Isolation and characterization of marine bacterial strain degrading fucoidan from Korean Undaria pinnatifida sporophylls. J Microbiol Biotechnol 18:616-623

Kohlmeyer J, Volkmann-Kohlmeyer B (2003) Marine Ascomycetes from algae and animal hosts. Bot Mar 46:285-306

Koivikko R, Loponen J, Honkanen T, Jormalainen V (2005) Contents of soluble, cell-wall-bound and exuded phlorotannins in the brown alga Fucus vesiculosus, with implications on their ecological functions. J Chem Ecol 31: 195-212

Kong MK, Chan KY (1979) A study on the bacterial flora isolated from marine algae. Bot Mar 22:83-97

König GM, Kehraus S, Seibert SF, Abdel-Lateff A, Müller D (2006) Natural products from marine organisms and their associated microbes. ChemBioChem 7:229-238

Koop K, Newell RC, Lucas MI (1982) Biodegradation and carbon flow based on kelp debris (Ecklonia maxima) in a sandy beach microcosm. Mar Ecol Prog Ser 7:315-326

Kraiwattanapong J, Tsuruga H, Ooi T, Kinoshita S (1999) Cloning and sequencing of a Deleya marina gene encoding for alginate lyase. Biotechnol Lett 21:169-174

Krug PJ, Fusetani N, Clare AS (eds) (2006) Defense of benthic invertebrates against surface colonization by larvae: a chemical arms race. Marine molecular biotechnology. Springer-Verlag, Berlin

Kubanek J, Jensen PR, Keifer PA, Sullards MC, Collins DO, Fenical W (2003) Seaweed resistance to microbial attack: a targeted chemical defense against marine fungi. Proc Natl Acad Sci USA 100:6916-6921

Küpper FC, Kloareg B, Guern J, Potin P (2001) Oligoguluronates elicit an oxidative burst in the brown algal kelp Laminaria digitata. Plant Physiol 125:278-291

Küpper FC, Müller DG, Peters AF, Kloareg B, Potin P (2002) Oligoalginate recognition and oxidative burst play a key role in natural and induced resistance of sporophytes of Laminariales. J Chem Ecol 28:2057-2081

Küpper FC, Gaquerel E, Boneberg EM, Morath S, Salaün JP, Potin P (2006) Early events in the perception of lipopolysaccharides in the brown alga Laminaria digitata include an oxidative burst and activation of fatty acid oxidation cascades. J Exp Bot 57:1991-1999

- Küpper FC, Gaquerel E, Cosse A, Adas F and others (2009) Free fatty acids and methyl jasmonate trigger defense reactions in Laminaria digitata. Plant Cell Physiol 50: $789-800$

Kurata K, Suzuki M, Shiraishi K, Taniguchi K (1988) Spatanetype diterpenes with biological activity from the brown alga Dilophus okamurai. Phytochemistry 27:1321-1324

Kusaykin MI, Chizhov AO, Grachev AA and others (2006) A comparative study of specificity of fucoidanases from marine microorganisms and invertebrates. J Appl Phycol $18: 369-373$

Kusuda R, Kawai K, Salati F, Kawamura Y, Yamashita Y (1992) Characteristics of Flavobacterium sp. causing 'suminori' disease in cultivated Porphyra. Suisanzoshoku 40: 457-461

Lachnit T, Blümel M, Imhoff JF, Wahl M (2009) Specific epibacterial communities on macroalgae: phylogeny matters more than habitat. Aquat Biol 5:181-186

Lachnit T, Wahl M, Harder T (2010) Isolated thallus-associated compounds from the macroalga Fucus vesiculosus mediate bacterial surface colonization in the field similar to that on the natural alga. Biofouling 26:247-255

Lakshmanaperumalsamy P, Purushothaman A (1982) Heterotrophic bacteria associated with seaweed. Proc Indian Acad Sci (Plant Sci) 91:487-493

Lam C, Stang A, Harder T (2008a) Planktonic bacteria and fungi are selectively eliminated by exposure to marine macroalgae in close proximity. FEMS Microbiol Ecol 63:283-291

Lam C, Grage A, Schulz D, Schulte A, Harder T (2008b) Extracts of North Sea macroalgae reveal specific activity patterns against attachment and proliferation of benthic diatoms: a laboratory study. Biofouling 24:59-66

Lane AL, Kubanek J (2008) Secondary metabolite defenses against pathogens and biofoulers. In: Amsler $\mathrm{CH}$ (ed) Algal chemical ecology, Chap. 11. Springer, Berlin, p 229-243

> Lane AL, Nyadong L, Galhena AS, Shearer TL and others (2009) Desorption electrospray ionization mass spectrometry reveals surface-mediated antifungal chemical defense of a tropical seaweed. Proc Natl Acad Sci USA 106: $7314-7319$

> Largo DB, Fukami K, Nishijima T (1995) Occasional pathogenic bacteria promoting ice-ice disease in the carrageenan-producing red algae Kappaphycus alvarezii and Eucheuma denticulatum (Solieriaceae, Gigartinales, Rhodophyta). J Appl Phycol 7:545-554

> Largo DB, Fukami K, Adachi M, Nishijima T (1997) Direct enumeration of bacteria from macroalgae by epifluorescence microscopy as applied to the fleshy red algae Kappaphycus alvarezii and Gracilaria spp. (Rhodophyta). J Phycol 33:554-557

Largo DB, Fukami K, Adachi M, Nishijima T (1998) Immunofluorescent detection of ice-ice disease-promoting bacterial strain Vibrio sp. P11 of the farmed macroalga, Kappaphycus alvarezii (Gigartinales, Rhodophyta). J Mar Biotechnol 6:178-182

> Largo DB, Fukami K, Nishijima T (1999) Time-dependent attachment mechanism of bacterial pathogen during iceice infection in Kappaphycus alvarezii (Gigartinales, Rhodophyta). J Appl Phycol 11:129-136

Larkum AWD, Kühl M (2005) Chlorophyll $d$ : the puzzle resolved. Trends Plant Sci 10:355-357

Lavilla-Pitogo CR (1992) Agar-digesting bacteria associated with 'rotten thallus syndrome' of Gracilaria sp. Aquaculture 102:1-7

> Laycock RA (1974) The detrital food chain based on seaweeds. 1. Bacteria associated with the surface of Laminaria fronds. Mar Biol 25:223-231 
Lee SD (2006) Phycicoccus jejuensis gen. nov., sp. nov., an Actinomycete isolated from seaweed. Int $\mathrm{J}$ Syst Evol Microbiol 56:2369-2373

Lee SD (2007) Labedella gwakjiensis gen. nov., sp. nov., a novel Actinomycete of the family Microbacteriaceae. Int J Syst Evol Microbiol 57:2498-2502

$>$ Lee SD (2008) Agrococcus jejuensis sp. nov., isolated from dried seaweed. Int J Syst Evol Microbiol 58:2297-2300

Lee SD, Kim SJ (2007) Aeromicrobium tamlense sp. nov., isolated from dried seaweed. Int J Syst Evol Microbiol 57: 337-341

Lee DW, Lee SD (in press) Koreibacter algae gen. nov., sp. nov., isolated from seaweed. Int J Syst Evol Microbiol. doi: 10.1099/ijs.0.014647-0

Lee YK, Jung HJ, Lee HK (2006) Marine bacteria associated with the Korean brown alga, Undaria pinnatifida. J Microbiol 44:694-698

Lee DW, Lee JM, Seo JP, Schumann P, Kim SJ, Lee SD (2008a) Phycicola gilvus gen. nov., sp. nov., an actinobacterium isolated from living seaweed. Int J Syst Evol Microbiol 58: 1318-1323

Lee HS, Kwon KK, Yang SH, Bae SS, Park CH, Kim SJ, Lee JH (2008b) Description of Croceitalea gen. nov. in the family Flavobacteriaceae with two species, Croceitalea eckloniae sp. nov. and Croceitalea dokdonensis sp. nov., isolated from the rhizosphere of the marine alga Ecklonia kurome. Int J Syst Evol Microbiol 58:2505-2510

> Lemos ML, Toranzo AE, Barja JL (1985) Antibiotic activity of epiphytic bacteria isolated from intertidal seaweeds. Microb Ecol 11:149-163

Lewis TE, Garland CD, McMeekin TA (1985) The bacterial biota on crustose (nonarticulated) coralline algae from Tasmanian waters. Microb Ecol 11:221-230

Liot F, Colin A, Mabeau S (1993) Microbiology and storage life of fresh edible seaweeds. J Appl Phycol 5:243-247

Littler MM, Littler DS (1994) A pathogen of reef-building coralline algae discovered in the South Pacific. Coral Reefs 13:202

Littler MM, Littler DS (1995) Impact of CLOD pathogen on Pacific Coral Reefs. Science 267:1356-1360

Lobban CS, Harrison PJ (1996) Seaweed ecology and physiology. Cambridge University Press, Cambridge

Longford SR, Tujula NA, Crocetti G, Holmes AJ and others (2007) Comparisons of diversity of bacterial communities associated with three sessile marine eukaryotes. Aquat Microb Ecol 48:217-229

Lu K, Lin W, Liu J (2008) The characteristics of nutrient removal and inhibitory effect of Ulva clathrata on Vibrio anguillarum 65. J Appl Phycol 20:1061-1068

Lustigman B, Lee LH, Thees N, Masucci J (1992) Production of antibacterial substances by macroalgae of the New York/New Jersey Coast, USA. Bull Environ Contam Toxicol 49:743-749

Ma Y, Liu P, Yu S, Li D, Cao S (2009) Inhibition of common fouling organisms in mariculture by epiphytic bacteria from the surfaces of seaweeds and invertebrates. Acta Ecol Sin 29:222-226

Macaya EC, Thiel M (2008) In situ tests on inducible defenses in Dictyota kunthii and Macrocystis integrifolia (Phaeophyceae) from the Chilean coast. J Exp Mar Biol Ecol 354: 28-38

> Macaya E, Rothäusler E, Molis M, Wahl M, Thiel M (2005) Induction of defenses and within-alga variation of palatability in two brown algae from the northern-central coast of Chile: effects of mesograzers and UV radiation. J Exp Mar Biol Ecol 325:214-227

Mahmud ZH, Neogi SB, Kassu A, Wada T, Islam MS, Nair GB,
Ota F (2007) Seaweeds as a reservoir for diverse Vibrio parahaemolyticus populations in Japan. Int J Food Microbiol 118:92-96

> Manefield M, de Nys R, Kumar N, Read R, Givskov M, Steinberg P, Kjelleberg S (1999) Evidence that halogenated furanones from Delisea pulchra inhibit acylated homoserine lactone (AHL)-mediated gene expression by displacing the AHL signal from its receptor protein. Microbiology 145:283-291

Manefield M, Rasmussen TB, Henzter M, Andersen JB, Steinberg P, Kjelleberg S, Givskov M (2002) Halogenated furanones inhibit quorum sensing through accelerated LuxR turnover. Microbiology (NY) 148:1119-1127

> Marshall K, Joint I, Callow ME (2006) Effect of marine bacterial isolates on the growth and morphology of axenic plantlets of the green alga Ulva linza. Microb Ecol 52: 302-310

Maruyama A, Maeda M, Simidu U (1990) Distribution and classification of marine bacteria with the ability of cytokinin and auxin production. Bull Jpn Soc Microb Ecol 5:1-8

Matsuo Y, Suzuki M, Kasai H, Shizuri Y, Harayama S (2003) Isolation and phylogenetic characterization of bacteria capable of inducing differentiation in the green alga Monostroma oxyspermum. Environ Microbiol 5:25-35

Matsuo Y, Imagawa H, Nishizawa M, Shizuri Y (2005) Isolation of an algal morphogenesis inducer from a marine bacterium. Science 307:1598

Matz C, Webb JS, Schupp PJ, Phang SY and others (2008) Marine biofilm bacteria evade eukaryotic predation by targeted chemical defense. PLoS ONE 3:e2744

> Maximilien R, de Nys R, Holmström C, Gram L and others (1998) Chemical mediation of bacterial surface colonization by secondary metabolites from the red alga Delisea pulchra. Aquat Microb Ecol 15:233-246

> Mazure HGF, Field JG (1980) Density and ecological importance of bacteria on kelp fronds in an upwelling region. J Exp Mar Biol Ecol 43:173-182

McBride DL, Kugrens P, West J (1974) Light and electron microscopic observations on red algal galls. Protoplasma 79:249-264

Mearns-Spragg A, Bregu M, Boyd KG, Burgess JG (1998) Cross-species induction and enhancement of antimicrobial activity produced by epibiotic bacteria from marine algae and invertebrates, after exposure to terrestrial bacteria. Lett Appl Microbiol 27:142-146

Medeiros HE, Da Gama BAP, Gallerani G (2007) Antifouling activity of seaweed extracts from Guarujá, São Paulo, Brazil. Braz J Oceanogr 55:257-264

> Mehrtens G, Laturnus F (1997) Halogenating activity in an arctic population of brown macroalga Laminaria saccharina (L.) Lamour. Polar Res 16:19-25

Menezes CBA, Bonugli-Santos RC, Miqueletto PB, Passarini MRZ and others (in press) Microbial diversity associated with algae, ascidians and sponges from the north coast of Sao Paulo state, Brazil. Microbiol Res

> Meusnier I, Olsen JL, Stam WT, Destombe C, Valero M (2001) Phylogenetic analyses of Caulerpa taxifolia (Chlorophyta) and of its associated bacterial microflora provide clues to the origin of the Mediterranean introduction. Mol Ecol 10:931-946

Meyer KD, Paul VJ (1992) Intraplant variation in secondary metabolite concentration in three species of Caulerpa (Chlorophyta: Caulerpales) and its effects on herbivorous fishes. Mar Ecol Prog Ser 82:249-257

> Michel G, Nyval-Collen P, Barbeyron T, Czjzek M, Helbert W (2006) Bioconversion of red seaweed galactans: a focus on 
bacterial agarases and carrageenases. Appl Microbiol Biotechnol 71:23-33

Mindl B, Sonntag B, Pernthaler J, Vrba J, Psenner R, Posch T (2005) Effects of phosphorus loading on interactions of algae and bacteria: reinvestigation of the 'phytoplanktonbacteria paradox' in a continuous cultivation system. Aquat Microb Ecol 38:203-213

Miyashita M, Fujimura S, Nakagawa Y, Nishizawa M, Tomizuka N, Nakagawa T, Nakagawa J (2010) Flavobacterium algicola sp. nov., isolated from marine algae. Int $\mathrm{J}$ Syst Evol Microbiol 60:344-348

Moran AC, Hengst MB, De La Iglesia R, Andrade S, Correa JA, Gonzalez B (2008) Changes in bacterial community structure associated with coastal copper enrichment. Environ Toxicol Chem 27:2239-2245

> Moreira LRS, Filho EXF (2008) An overview of mannan structure and mannan-degrading enzyme systems. Appl Microbiol Biotechnol 79:165-178

Mow-Robinson JM, Rheinheimer G (1985) Comparison of bacterial populations from the Kiel Fjord in relation to the presence or absence of benthic vegetation. Bot Mar 28: 29-39

> Murakami A, Miyashita H, Iseki M, Adachi K, Mimuro M (2004) Chlorophyll $d$ in an epiphytic cyanobacterium of red algae. Science 303:1633

Musa N, Wei LS (2008) Bacteria attached on cultured seaweed Gracilaria changii at Mengabang Telipot, Terengganu. Acad J Plant Sci 1:1-4

> N'Diaye I, Guella G, Mancini I, Pletra F (1996) Almazole D, a new type of antibacterial 2,5-disubstituted oxazolic dipeptide from a red alga of the coast of Senegal. Tetrahedron Lett 37:3049-3050

Nagao T, Adachi K, Sakai M, Nishijima M, Sano H (2001) Novel macrolactins as antibiotic lactones from a marine bacterium. J Antibiot (Tokyo) 54:333-339

Nakagawa Y, Yamasato K (1996) Emendation of the genus Cytophaga and transfer of Cytophaga agarovorans and Cytophaga salmonicolor to Marinilabilia gen. nov.: phylogenetic analysis of the Flavobacterium-Cytophaga complex. Int J Syst Bacteriol 46:599-603

Nakanishi K, Nishijima M, Nishimura M, Kuwano K, Saga N (1996) Bacteria that induce morphogenesis in Ulva pertusa (Chlorophyta) grown under axenic conditions. J Phycol 32: 479-482

Nakanishi K, Nishijima M, Nomoto AM, Yamazaki A, Saga N (1999) Requisite morphologic interaction for attachment between Ulva pertusa (Chlorophyta) and symbiotic bacteria. Mar Biotechnol 1:107-111

Nakao Y, Onohara T, Matsubara T, Fujita Y, Zenitani B (1972) Bacteriological studies on diseases of cultured laver. I. Green spot rotting-like deterioration of laver frond by bacteria in vitro. Bull Jpn Soc Sci Fish 38:561-564

> Nedashkovskaya OI, Kim SB, Han SK, Lysenko AM and others (2003) Mesonia algae gen. nov., sp. nov., a novel marine bacterium of the family Flavobacteriaceae isolated from the green alga Acrosiphonia sonderi (Kütz) Kornm. Int J Syst Evol Microbiol 53:1967-1971

Nedashkovskaya OI, Kim SB, Han SK, Lysenko AM, Mikhailov VV, Bae KS (2004a) Arenibacter certesii sp. nov., a novel marine bacterium isolated from the green alga Ulva fenestrata. Int J Syst Evol Microbiol 54: 1173-1176

Nedashkovskaya OI, Suzuki M, Vancanneyt M, Cleenwerck I, Lysenko AM, Mikhailov VV, Swings J (2004b) Zobellia amurskyensis sp. nov., Zobellia laminariae sp. nov. and Zobellia russellii sp. nov., novel marine bacteria of the family Flavobacteriaceae. Int J Syst Evol Microbiol 54:
1643-1648

Nedashkovskaya OI, Kim SB, Han SK, Rhee MS and others (2004c) Ulvibacter litoralis gen. nov., sp. nov., a novel member of the family Flavobacteriaceae isolated from the green alga Ulva fenestrata. Int J Syst Evol Microbiol 54: 119-123

> Nedashkovskaya OI, Kim SB, Han SK, Lysenko AM and others (2004d) Maribacter gen. nov., a new member of the family Flavobacteriaceae, isolated from marine habitats, containing the species Maribacter sedimenticola sp. nov., Maribacter aquivivus sp. nov., Maribacter orientalis sp. nov. and Maribacter ulvicola sp. nov. Int J Syst Evol Microbiol 54:1017-1023

> Nedashkovskaya OI, Kim SB, Han SK, Rhee MS and others (2004e) Algibacter lectus gen. nov., sp. nov., a novel member of the family Flavobacteriaceae isolated from green algae. Int J Syst Evol Microbiol 54:1257-1261

> Nedashkovskaya OI, Kim SB, Lee KH, Bae KS, Frolova GM, Mikhailov VV, Kim IS (2005a) Pibocella ponti gen. nov., sp. nov., a novel marine bacterium of the family Flavobacteriaceae isolated from the green alga Acrosiphonia sonderi. Int J Syst Evol Microbiol 55:177-181

Nedashkovskaya OI, Kim SB, Lee DH, Lysenko AM and others (2005b) Roseivirga ehrenbergii gen. nov., sp. nov., a novel marine bacterium of the phylum 'Bacteroidetes', isolated from the green alga Ulva fenestrata. Int J Syst Evol Microbiol 55:231-234

> Nedashkovskaya OI, Kim SB, Han SK, Snauwaert C and others (2005c) Winogradskyella thalassocola gen. nov., sp. nov., Winogradskyella epiphytica sp. nov. and Winogradskyella eximia sp. nov., marine bacteria of the family Flavobacteriaceae. Int J Syst Evol Microbiol 55:49-55

Nedashkovskaya OI, Kim SB, Vancanneyt M, Snauwaert C and others (2006a) Formosa agariphila sp. nov., a budding bacterium of the family Flavobacteriaceae isolated from marine environments, and emended description of the genus Formosa. Int J Syst Evol Microbiol 56:161-167

> Nedashkovskaya OI, Vancanneyt M, Cleenwerck I, Snauwaert C and others (2006b) Arenibacter palladensis sp. nov., a novel marine bacterium isolated from the green alga Ulva fenestrata, and emended description of the genus Arenibacter. Int J Syst Evol Microbiol 56:155-160

Nedashkovskaya OI, Vancanneyt M, De Vos P, Kim SB, Lee MS, Mikhailov VV (2007) Maribacter polysiphoniae sp. nov., isolated from a red alga. Int J Syst Evol Microbiol $57: 2840-2843$

> Nedashkovskaya OI, Kwon KK, Yang SH, Lee HS, Chung KH, Kim SJ (2008) Lacinutrix algicola sp. nov. and Lacinutrix mariniflava sp. nov., two novel marine alga-associated bacteria and emended description of the genus Lacinutrix. Int J Syst Evol Microbiol 58:2694-2698

> Nedashkovskaya OI, Suzuki M, Lee JS, Lee KC, Shevchenko LS, Mikhailov VV (2009) Pseudozobellia thermophila gen. nov., sp. nov., a bacterium of the family Flavobacteriaceae, isolated from the green alga Ulva fenestrata. Int J Syst Evol Microbiol 59:806-810

> Nishijima M, Takadera T, Imamura N, Kasai H and others (2009) Microbulbifer variabilis sp. nov. and Microbulbifer epialgicus sp. nov., isolated from Pacific marine algae, possess a rod-coccus cell cycle in association with the growth phase. Int J Syst Evol Microbiol 59:1696-1707

> Nyadong L, Hohenstein EG, Galhena A, Lane AL, Kubanek J, Sherrill CD, Fernández FM (2009) Reactive desorption electrospray ionization mass spectrometry (DESI-MS) of natural products of a marine alga. Anal Bioanal Chem 394:245-254

Nylund GM, Pavia H (2005) Chemical versus mechanical 
inhibition of fouling in the red alga Dilsea carnosa. Mar Ecol Prog Ser 299:111-121

> Nylund GM, Cervin G, Persson F, Hermansson M, Steinberg PD, Pavia H (2008) Seaweed defence against bacteria: a poly-brominated 2-heptanone from the red alga Bonnemaisonia hamifera inhibits bacterial colonisation. Mar Ecol Prog Ser 369:39-50

Nylund GM, Persson F, Lindegarth M, Cervin G, Hermansson M, Pavia H (2010) The red alga Bonnemaisonia asparagoides regulates epiphytic bacterial abundance and community composition by chemical defence. FEMS Microbiol Ecol 71:84-93

Ohkubo S, Miyashita H, Murakami A, Takeyama H, Tsuchiya T, Mimuro M (2006) Molecular detection of epiphytic Acaryochloris spp. on marine macroalgae. Appl Environ Microbiol 72:7912-7915

> Okazaki T, Kitahara T, Okami Y (1975) Studies on marine microorganisms. IV. A new antibiotic SS-228Y produced by Chainia isolated from shallow sea mud. J Antibiot (Tokyo) 28:176-184

> Palmer CJ, Anders TL, Carpenter LJ, Küpper FC, McFiggans G (2005) Iodine and halocarbon response of Laminaria digitata to oxidative stress and links to atmospheric new particle production. Environ Chem 2:282-290

$>$ Pang SJ, Xiao T, Bao Y (2006a) Dynamic changes of total bacteria and Vibrio in an integrated seaweed-abalone culture system. Aquaculture 252:289-297

Pang SJ, Xiao T, Shan TF, Wang ZF, Gao SQ (2006b) Evidences of the inter tidal red alga Grateloupia turuturu in turning Vibrio parahaemolyticus into non-culturable state in the presence of light. Aquaculture 260:369-374

> Paradas WC, Salgado LT, Sudatti DB, Crapez MA and others (2010) Induction of halogenated vesicle transport in cells of the red seaweed Laurencia obtusa. Biofouling 26: $277-286$

Park CS, Kakinuma M, Amano H (2006) Forecasting infections of the red rot disease on Porphyra yezoensis Ueda (Rhodophyta) cultivation farms. J Appl Phycol 18:295-299

> Park SC, Baik KS, Kim MS, Kim SS and others (2009) Aequorivita capsosiphonis sp. nov., isolated from the green alga Capsosiphon fulvescens, and emended description of the genus Aequorivita. Int J Syst Evol Microbiol 59:724-728

Parsek MR, Greenberg EP (2000) Acyl-homoserine lactone quorum sensing in Gram-negative bacteria: a signaling mechanism involved in associations with higher organisms. Proc Natl Acad Sci USA 97:8789-8793

$>$ Patel P, Callow ME, Joint I, Callow JA (2003) Specificity in the settlement-modifying response of bacterial biofilms towards zoospores of the marine alga Enteromorpha. Environ Microbiol 5:338-349

Paul VJ, Puglisi MP (2004) Chemical mediation of interactions among marine organisms. Nat Prod Rep 21:189-209

> Paul VJ, Ritson-Williams R (2008) Marine chemical ecology. Nat Prod Rep 25:662-695

Paul VJ, Littler MM, Littler DS, Fenical W (1987) Evidence for chemical defense in tropical green alga Caulerpa ashmeadii (Caulerpaceae: Chlorophyta): isolation of new bioactive sesquiterpenoids. J Chem Ecol 13:1171-1185

Paul NA, de Nys R, Steinberg PD (2006) Chemical defense against bacteria in the red alga Asparagopsis armata: linking structure with function. Mar Ecol Prog Ser 306:87-101

Pawlik JR (2000) Marine chemical ecology. Mar Ecol Prog Ser 207:225-226

Pellegrini M, Pellegrini L (1982) Some observations on relationships between bacteria and a brown alga. Biol Cell 43: 195-200
Penesyan A, Marshall-Jones Z, Holmstrom C, Kjelleberg S, Egan S (2009) Antimicrobial activity observed among cultured epiphytic bacteria reflects their potential as source of new drugs. FEMS Microbiol Ecol 69:113-124

- Penesyan A, Kjelleberg S, Egan S (2010) Development of novel drugs from marine surface associated microorganisms. Mar Drugs 8:438-459

Perry NB, Blunt JW, Munro MH (1991) A cytotoxic and antifungal 1,4-naphthoquinone and related compounds from a New Zealand brown algae, Landsburgia quercifolia. J Nat Prod 54:978-985

> Phillips DW, Towers GHN (1982) Chemical ecology of red algal bromophenols. I. Temporal, interpopulational and within-thallus measurements of lanosol levels in Rhodomela larix (Turner) C. Agardh. J Exp Mar Biol Ecol 58:285-293

Plouguerne E, Hellio C, Deslandes E, Veron B, Stiger-Pouvreau V (2008) Antimicrofouling activities in extracts of two invasive algae: Grateloupia turuturu and Sargassum muticum. Bot Mar 51:202-208

Polne-Fuller M, Gibor A (1987) Microorganisms as digesters of seaweed cell walls. Hydrobiologia 151-152:405-409

Potin P (2008) Oxidative burst and related responses in biotic interactions of algae. In: Amsler $\mathrm{CH}$ (ed) Algal chemical ecology, Chap 12. Springer, Berlin, p 245-271

Potin P, Sanseau A, Le Gall Y, Rochas C, Kloareg B (1991) Purification and characterization of a new kappacarrageenase from a marine Cytophaga-like bacterium. Eur J Biochem 201:241-247

> Potin P, Bouarab K, Küpper F, Kloareg B (1999) Oligosaccharide recognition signals and defense reactions in marine plant-microbe interactions. Curr Opin Microbiol 2: 276-283

Potin P, Bouarab K, Salaün JP, Pohnert G, Kloareg B (2002) Biotic interactions of marine algae. Curr Opin Plant Biol 5:308-317

Preston JF III, Romeo T, Bromley JC (1986) Selective alginate degradation by marine bacteria associated with the algal genus Sargassum. J Ind Microbiol 1:235-244

Provasoli L, Pintner IJ (1972) Effect of bacteria on seaweed morphology. J Phycol 8(Suppl.):10

Provasoli L, Pintner IJ (1980) Bacteria induced polymorphism in axenic laboratory strain of Ulva lactuca (Chlorophyceae). J Phycol 16:196-201

Puglisi MP, Tan LT, Jensen PR, Fenical W (2004) Capisterones A and B from the tropical green alga Penicillus capitatus: unexpected anti-fungal defenses targeting the marine pathogen Lindra thallasiae. Tetrahedron 60:7035-7039

Puglisi MP, Engel S, Jensen PR, Fenical W (2007) Antimicrobial activities of extracts from Indo-Pacific marine plants against marine pathogens and saprophytes. Mar Biol 150: $531-540$

Qian PY, Lau SCK, Dahms HU, Dobretsov SV, Harder T (2007) Marine biofilms as mediators of colonization by marine macroorganisms: implications for antifouling and aquaculture. Mar Biotechnol 9:399-410

> Quatrano RS, Caldwell BA (1978) Isolation of a unique marine bacterium capable of growth on a variety of polysaccharides from macroalgae. Appl Environ Microbiol 36: 979-981

> Raghukumar S (2002) Ecology of the marine protists, the Labyrinthulomycetes (Thraustochytrids and Labyrinthulids). Eur J Protistol 38:127-145

- Rajamani S, Bauer WD, Robinson JB, Farrow JM III and others (2008) The vitamin riboflavin and its derivative lumichrome activate the LasR bacterial quorum-sensing receptor. Mol Plant Microbe Interact 21:1184-1192 
Ramaiah N, Chandramohan D (1992) Densities, cellulases, alginate and pectin lyases of luminous and other heterotrophic bacteria associated with marine algae. Aquat Bot 44:71-81

Rao US, Fujita Y (2000) Carbohydrate regulation of attachment, encystment, and appressorium formation by Pythium porphyrae (Oomycota) zoospores on Porphyra yezoensis (Rhodophyta). J Phycol 36:359-366

Rao D, Webb JS, Kjelleberg S (2005) Competitive interactions in mixed-species biofilms containing the marine bacterium Pseudoalteromonas tunicata. Appl Environ Microbiol 71:1729-1736

Rao D, Webb JS, Kjelleberg S (2006) Microbial colonization and competition on the marine alga Ulva australis. Appl Environ Microbiol 72:5547-5555

Rao D, Webb JS, Holmström C, Case R, Low A, Steinberg P, Kjelleberg S (2007) Low densities of epiphytic bacteria from the marine alga Ulva australis inhibits settlement of fouling organisms. Appl Environ Microbiol 73:7844-7852

Rasmussen TB, Manefield M, Andersen JB, Eberl L and others (2000) How Delisea pulchra furanones affect quorum sensing and swarming motility in Serratia liquefaciens MG1. Microbiology (NY) 146:3237-3244

Ren D, Sims JJ, Wood TK (2002) Inhibition of biofilm formation and swarming of Bacillus subtilis by (5Z)-4-bromo-5(bromomethylene)-3-butyl-2(5H)-furanone. Lett Appl Microbiol 34:293-299

Riquelme C, Rojas A, Flores V, Correa JA (1997) Epiphytic bacteria in a copper-enriched environment in Northern Chile. Mar Pollut Bull 34:816-820

Roland W (1975) Epiphytism and endophytism of Macrocystis integrifolia and Nereocystis luetkeana: seasonality, succession and tactics on temporary, living substrate. MSc thesis, University of Victoria, Victoria, British Columbia

Romanenko LA, Zhukova NV, Rohde M, Lysenko AM, Mikhailov VV, Stackebrandt E (2003) Pseudoalteromonas agarivorans sp. nov., a novel marine agarolytic bacterium. Int J Syst Evol Microbiol 53:125-131

Rosenberg G, Paerl HW (1981) Nitrogen fixation by bluegreen algae associated with the siphonous green seaweed Codium decorticatum: effects on ammonium uptake. Mar Biol 61:151-158

Rungprom W, Ro Siwu E, Lambert LK, Dechsakulwatana C and others (2008) Cyclic tetrapeptides from marine bacteria associated with the seaweed Diginea sp. and the sponge Halisarca ectofibrosa. Tetrahedron 64:3147-3152

Sakai T, Kimura H, Kato I (2002) A marine strain of Flavobacteriaceae utilizes brown seaweed fucoidan. Mar Biotechnol 4:399-405

Sakai T, Ishizuka K, Kato I (2003) Isolation and characterization of a fucoidan-degrading marine bacterium. Mar Biotechnol 5:409-416

Sakai T, Kawai T, Kato I (2004) Isolation and characterization of a fucoidan-degrading marine bacterial strain and its fucoidanase. Mar Biotechnol 6:335-346

Sakami T (1996) Effects of algal excreted substances on the respiration activities of epiphytic bacteria on the brown alga, Eisenia bicyclis Kjellman. Fish Sci 62:394-396

Sakami T (1999) Effects of algal excreted matters on epiphytic bacteria on the brown alga, Eisenia bicyclis. Bull Natl Res Inst Aquacult 28:39-90

Sakami T, Sugiyama M (1994) Effects of algal excreted organic matter on the bacterial population of a brown alga Eisenia bicyclis. Nippon Suisan Gakkaishi 60:473-477

Salaün S, Kervarec N, Potin P, Haras D, Piotto M, La Barre S (2010) Whole-cell spectroscopy is a convenient tool to assist molecular identification of cultivatable marine bac- teria and to investigate their adaptive metabolism. Talanta 80:1758-1770

Sandsdalen E, Haug T, Stensvag K, Styrvold OB (2003) The antibacterial effect of a polyhydroxylated fucophlorethol from the marine brown alga, Fucus vesiculosus. World J Microbiol Biotechnol 19:777-782

- Sarwar G, Sakata T, Kakimoto D (1983) Isolation and characterization of carrageenan-decomposing bacteria from marine environment. J Gen Appl Microbiol 29:145-155

Sawabe T, Ezura Y, Kimura T (1992) Characterization of an alginolytic marine bacterium from decaying rishirikombu Laminaria japonica var. ochotensis. Nippon Suisan Gakkaishi 58:141-145

Sawabe T, Ohtsuka M, Ezura Y (1997) Novel alginate lyases from marine bacterium Alteromonas sp. strain H-4. Carbohydr Res 304:69-76

Sawabe T, Sawada C, Suzuki E, Ezura Y (1998a) Intracellular alginate oligosaccharide degrading enzyme activity that is incapable of degrading intact sodium alginate from a marine bacterium Alteromonas sp. Fish Sci 64:320-334

Sawabe T, Makino H, Tatsumi M, Nakano K and others (1998b) Pseudoalteromonas bacteriolytica sp. nov., a marine bacterium that is the causative agent of red spot disease of Laminaria japonica. Int J Syst Bacteriol 48: 769-774

Sawabe T, Tanaka R, Iqbal MM, Tajima K, Ezura Y, Ivanova EP, Christen R (2000) Assignment of Alteromonas elyakovii KMM162T and five strains isolated from spot wounded fronds of Laminaria japonica to Pseudoalteromonas elyakovii comb. nov. and the extended description of the species. Int J Syst Bacteriol 50:265-271

- Sawabe T, Fujimura Y, Niwa K, Aono H (2007) Vibrio comitans sp. nov., Vibrio rarus sp. nov. and Vibrio inusitatus sp. nov., from the gut of the abalones Haliotis discus discus, $H$. gigantea, H. madaka and $H$. rufescens. Int J Syst Evol Microbiol 57:916-922

Scheuer PJ (ed) (1978) Marine natural products, Vol 1. Academic Press, London

Schlenk D, Gerwick WH (1987) Dilophic acid a diterpenoid from the tropical brown seaweed Dilophus guineensis. Phytochemistry 26:1081-1084

Schmidt EW (2005) From chemical structure to environmental biosynthetic pathways: navigating marine invertebratebacteria associations. Trends Biotechnol 23:437-440

> Schmitt TM, Hay ME, Lindquist N (1995) Constraints on chemically mediated coevolution: multiple functions for seaweed secondary metabolites. Ecology 76:107-123

- Schroeder DC, Jaffer MA, Coyne VE (2003) Investigation of the role of a beta (1-4) agarase produced by Pseudoalteromonas gracilis B9 in eliciting disease symptoms in the red alga Gracilaria gracilis. Microbiology (NY) 149: $2919-2929$

Semenova EV, Shlykova DS, Semenov AM, Ivanov MN, Shelyakov OV, Netrusov AI (2009) Bacteria epiphytes of brown macro alga in oil utilization in North Sea ecosystems. Moscow Univ Biol Sci Bull 64:107-110

Shiba T, Simidu U (1982) Erythrobacter longus gen. nov., sp. nov., an aerobic bacterium which contains bacteriochlorophyll a. Int J Syst Bacteriol 32:211-217

Shiba TO, Taga N (1980) Heterotrophic bacteria attached to seaweeds. J Exp Mar Biol Ecol 47:251-258

Shiba T, Simidu U, Taga N (1979) Distribution of aerobic bacteria which contain bacteriochlorophyll a. Appl Environ Microbiol 38:43-45

Sieburth JM, Conover JT (1965) Sargassum tannin, an antibiotic which retards fouling. Nature 208:52-53

Sieburth JM, Jensen A (1967) Effect of processing on the 
microflora of Norwegian seaweed meal, with observations on Sporendonema minutum (Hoye) Frank and Hess. Appl Microbiol 15:830-838

Sieburth JM, Tootle JL (1981) Seasonality of microbial fouling on Ascophyllum nodosum (L.) Lejol., Fucus vesiculosus L., Polysiphonia lanosa (L.) Tandy and Chondrus crispus Stackh. J Phycol 17:57-64

Silva-Aciares F, Riquelme C (2008) Inhibition of attachment of some fouling diatoms and settlement of Ulva lactuca zoospores by film-forming bacterium and their extracellular products isolated from biofouled substrata in Northern Chile. Electron J Biotechnol 11, No. 1

Simidu U, Kita-Tsukamoto K, Yasumoto T, Yotsu M (1990) Taxonomy of four marine bacterial strains that produce tetrodotoxin. Int J Syst Bacteriol 40:331-336

Skindersoe ME, Ettinger-Epstein P, Rasmussen TB, Bjarnsholt T, de Nys R, Givskov M (2008) Quorum sensing antagonism from marine organisms. Mar Biotechnol 10:56-63

Skovhus TL, Ramsing NB, Holmström C, Kjelleberg S, Dahllöf I (2004) Real-time quantitative PCR for assessment of abundance of Pseudoalteromonas species in marine samples. Appl Environ Microbiol 70:2373-2382

Skovhus TL, Holmström C, Kjelleberg S, Dahllöf I (2007) Molecular investigation of the distribution, abundance and diversity of the genus Pseudoalteromonas in marine samples. FEMS Microbiol Ecol 61:348-361

Smit AJ (2004) Medicinal and pharmaceutical uses of seaweed natural products: a review. J Appl Phycol 16: 245-262

Staufenberger T, Thiel V, Wiese J, Imhoff JF (2008) Phylogenetic analysis of bacteria associated with Laminaria saccharina. FEMS Microbiol Ecol 64:65-77

Steinberg PD, de Nys R (2002) Chemical mediation of colonization of seaweeds surfaces. J Phycol 38:621-629

Steinberg PD, Schneider R, Kjelleberg S (1997) Chemical defenses of seaweeds against microbial colonization. Biodegradation 8:211-220

Steinberg PD, de Nys R, Kjelleberg S (1998) Chemical inhibition of epibiota by Australian seaweeds. Biofouling 12 : 227-244

Steinberg PD, de Nys R, Kjelleberg S (2002) Chemical cues for surface colonization. J Chem Ecol 28:1935-1951

- Stevens RA, Levin RE (1977) Purification and characteristics of an alginase from Alginovibrio aquatilis. Appl Environ Microbiol 33:1156-1161

Sudatti DB, Rodrigues SV, Pereira RC (2006) Quantitative GC-ECD analysis of halogenated metabolites: determination of surface and within-thallus elatol of Laurencia obtusa. J Chem Ecol 32:835-843

Sudatti DB, Rodrigues SV, Coutinho R, da Gama BAP, Salgado LT, Filho GMA, Pereira RC (2008) Transport and defensive role of elatol at the surface of the red seaweed Laurencia obtusa (Ceramiales, Rhodophyta). J Phycol 44: 584-591

Sunairi M, Tsuchiya H, Tsuchiya T, Omura Y and others (1995) Isolation of a bacterium that causes anaaki disease of the red algae Porphyra yezoensis. J Appl Bacteriol 79: 225-229

Suzuki M, Daitoh M, Vairappan CS, Abe T, Masuda M (2001a) Novel halogenated metabolites from the Malaysian Laurencia pannosa. J Nat Prod 64:597-602

Suzuki M, Nakagawa Y, Harayama S, Yamamoto S (2001b) Phylogenetic analysis and taxonomic study of marine Cytophaga-like bacteria: proposal for Tenacibaculum gen. nov. with Tenacibaculum maritimum comb. nov., and Tenacibaculum ovolyticum comb. nov., and description of Tenacibaculum mesophilum sp. nov. and Tenacibaculum amylolyticum sp. nov. Int J Syst Evol Microbiol 51: 1639-1652

Tait K, Joint I, Daykin M, Milton DL, Williams P, Camara M (2005) Disruption of quorum sensing in seawater abolishes attraction of zoospores of the green alga Ulva to bacterial biofilms. Environ Microbiol 7:229-240

> Tanaka M, Umemoto Y, Okamura H, Nakano D, Tamaru Y, Araki T (2009) Cloning and characterization of a $\beta-1,4$ mannanase 5C possessing a family 27 carbohydrate-binding module from a marine bacterium, Vibrio sp. strain MA-138. Biosci Biotechnol Biochem 73:109-116

Tang J, Xiao Y, Oshima A, Kawai H, Nagata S (2008) Disposal of seaweed wakame (Undaria pinnatifida) in composting process by marine bacterium Halomonas sp. AW4. Int J Biotechnol 10:73-85

Tang JC, Taniguchi H, Chu H, Zhou Q, Nagata S (2009) Isolation and characterization of alginate-degrading bacteria for disposal of seaweed wastes. Lett Appl Microbiol 48: $38-43$

Tatewaki M, Provasoli L, Pintner J (1983) Morphogenesis of Monostroma oxyspermum (Kutz.) Doty (Chlorophyceae) in an axenic culture, especially in bialgal culture. J Phycol 19:409-416

Teplitski M, Chen H, Rajamani S, Gao M and others (2004) Chlamydomonas reinhardtii secretes compounds that mimic bacterial signals and interfere with quorum sensing regulation in bacteria. Plant Physiol 134:137-146

Than PP, Del Castillo CS, Yoshikawa T, Sakata T (2004) Extracellular protease production of bacteriolytic bacteria isolated from marine environments. Fish Sci 70:659-666

Thomas T, Evans FF, Schleheck D, Mai-Prochnow A and others (2008) Analysis of the Pseudoalteromonas tunicata genome reveals properties of a surface-associated life style in the marine environment. PLoS ONE 3:e3252

Tribollet A, Payri C (2001) Bioerosion of the coralline alga Hydrolithon onkodes by microborers in the coral reefs of Moorea, French Polynesia. Oceanol Acta 24:329-342

Tringali C, Piattelli M, Nicolosi G, Hostettmann K (1986) Molluscicidal and antifungal activity of diterpenoids from brown algae of the family Dictyotaceae. Planta Med 52: 404-406

Tripodi G, Beth K (1976) Unusual cell structures in tumor-like formations of Gracilaria (Rhodophyta). Arch Microbiol 108:167-174

> Trischman JA, Oeffner RE, De Luna MG, Kazaoka M (2004) Competitive induction and enhancement of indole and a diketopiperazine in marine bacteria. Mar Biotechnol 6: 215-220

Tsekos I (1982) Tumour-like growths induced by bacteria in the thallus of a red alga, Gigartina teedii (Roth) Lamour. Ann Bot (Lond) 49:123-126

Tseng CH, Yamaguchi K, Kitamikado M (1991) Two types of alginate lyase from a marine bacterium Vibrio sp. AL-9. Nippon Suisan Gakkaishi 58:743-749

Tsukidate J (1971) Microbiological studies of Porphyra plants II. Bacteria isolated from Porphyra leucosticta in culture. Nippon Suisan Gakkaishi 37:376-379

Tsukidate IJ (1977) Microbiological studies of Porphyra plants. V. On the relation between bacteria and Porphyra diseases. Bull Nansei Reg Fish Res Lab 10:101-112

Tsukidate J (1983) On the symbiotic relationship between Porphyra species and attached bacteria, and a bacterial pathogen in white rot. Bull Nansei Reg Fish Res Lab 15: 29-96

Tujula NA, Holmström C, Mußmann M, Amann R, Kjelleberg S, Crocetti GR (2006) A CARD-FISH protocol for the identification and enumeration of epiphytic bacteria on marine 
algae. J Microbiol Methods 65:604-607

Tujula NA, Crocetti GR, Burke C, Thomas T, Holmström C, Kjelleberg $S$ (2010) Variability and abundance of the epiphytic bacterial community associated with a green marine Ulvacean alga. ISME J 4:301-311

Turner JB, Friedmann EI (1974) Fine structure of capitular filaments in the coenocytic green alga Penicillus. J Phycol 10:125-134

Uchida M (1995) Enzyme activities of marine bacteria involved in Laminaria-thallus decomposition and the resulting sugar release. Mar Biol 123:639-644

Uchida M, Murata M (2004) Isolation of a lactic acid bacterium and yeast consortium from a fermented material of Ulva spp. (Chlorophyta). J Appl Microbiol 97:1297-1310

Uchida M, Nakayama A (1993) Isolation of Laminaria-frond decomposing bacteria from Japanese coastal waters. Nippon Suisan Gakkaishi 59:1865-1871

Uchida M, Nakayama A, Abe S (1995) Distribution and characterization of bacteria capable of decomposing brown algae fronds in waters associated with Laminaria vegetation. Fish Sci 61:117-120

Uchida M, Maeda T, Shiba T (2002) Phylogenic analysis of three marine bacteria that have ability to decompose Laminaria japonica. Fish Sci 68:703-705

> Urvantseva AM, Bakunina IY, Nedashkovskaya OI, Kim SB, Zvyagintseva TN (2006) Distribution of intracellular fucoidan hydrolases among marine bacteria of the family Flavobacteriaceae. Appl Biochem Microbiol 42:484-491

Uyenco F, Saniel LS, Jacinto GS (1981) The 'ice-ice' problem in seaweed farming. Proc Int Seaweed Symp 10:625-630

> Vairappan CS, Suzuki M (2000) Dynamics of total surface bacteria and bacterial species counts during dessication in the Malaysian sea lettuce, Ulva reticulata (Ulvales, Chlorophyta). Phycological Res 48:55-61

Vairappan CS, Suzuki M, Motomura T, Ichimura T (2001a) Pathogenic bacteria associated with lesions and thallus bleaching symptoms in the Japanese kelp Laminaria religiosa Miyabe (Laminariales, Phaeophyceae). Hydrobiologia 445:183-191

Vairappan CS, Suzuki M, Abe T, Masuda M (2001b) Halogenated metabolites with antibacterial activity from the Okinawan Laurencia species. Phytochemistry 58:517-523

- Vairappan CS, Chung CS, Hurtado AQ, Soya FE, Lhonneur GB, Critchley A (2008) Distribution and symptoms of epiphyte infection in major carrageenophyte-producing farms. J Appl Phycol 20:477-483

Vairappan CS, Anangdan SP, Tan KL, Matsunaga S (2010) Role of secondary metabolites as defense chemicals against ice-ice disease bacteria in biofouler at carrageenophyte farms. J Appl Phycol 22:305-311

Valdebenito HA, Bittner ML, Silva MJ, Sammes PG, Watson WH, Zemelmann R (1982) Metabolitos del alga roja Laurencia chilensis. 3-hidroxi-4-metil acetofenona, compuesto con actividad antibacteriana. Bol Soc Chil Quím 27:293-295

> Vera J, Alvarez R, Murano E, Slebe JC, Leon O (1998) Identification of a marine agarolytic Pseudoalteromonas isolate and characterization of its extracellular agarase. Appl Environ Microbiol 64:4378-4383

Vlachos V, Critchley AT, von Holy A (1999) Differential antibacterial activity of extracts from selected southern African macroalgal thalli. Bot Mar 42:165-173

Wahl M (1989) Marine epibiosis. I. Fouling and antifouling: some basic aspects. Mar Ecol Prog Ser 58:175-189

Wahl M (2008) Ecological lever and interface ecology: epibiosis modulates the interactions between host and environment. Biofouling 24:427-438
Wahl M, Jensen PR, Fenical W (1994) Chemical control of bacterial epibiosis on Ascidians. Mar Ecol Prog Ser 110: 45-57

Waite TD, Mitchell R (1976) Some benevolent and antagonistic relationships between Ulva lactuca and its microflora. Aquat Bot 2:13-22

- Wang G, Shuai L, Li Y, Lin W, Zhao X, Duan D (2008) Phylogenetic analysis of epiphytic marine bacteria on hole-rotten diseased sporophytes of Laminaria japonica. J Appl Phycol 20:403-409

- Wang YH, Yu GL, Wang XM, Lv ZH, Zhao X, Wu ZH, Ji WS (2006) Purification and characterization of alginate lyase from marine Vibrio sp. YWA. Acta Biochim Biophys Sin (Shanghai) 38:633-638

Wang Z, Xiao T, Pang S, Liu M, Yue H (2009) Isolation and identification of bacteria associated with the surfaces of several algal species. Chin J Oceanology Limnol 27: 487-492

Weinberger F (2007) Pathogen-induced defense and innate immunity in macroalgae. Biol Bull 213:290-302

- Weinberger F, Friedlander M (2000a) Endogenous and exogenous elicitors of a hypersensitive response in Gracilaria conferta (Rhodophyta). J Appl Phycol 12: 139-145

Weinberger F, Friedlander M (2000b) Response of Gracilaria conferta (Rhodophyta) to oligoagars results in defense against agar-degrading epiphytes. J Phycol 36:1079-1086

Weinberger F, Friedlander M, Gunkel W (1994) A bacterial facultative parasite of Gracilaria conferta. Dis Aquat Org 18:135-141

Weinberger F, Hoppe HG, Friedlander M (1997) Bacterial induction and inhibition of a fast necrotic response in Gracilaria conferta (Rhodophyta). J Appl Phycol 9:277-285

> Weinberger F, Friedlander M, Hoppe HG (1999) Oligoagars elicit an oxidative burst in Gracilaria conferta (Rhodophyta). J Phycol 35:747-755

Weinberger F, Pohnert G, Kloareg B, Potin P (2002) A signal released by an endophytic attacker acts as a substrate for a rapid defensive reaction of the red alga Chondrus crispus. ChemBioChem 3:1260-1263

- Weinberger F, Leonardi P, Miravalles A, Correa JA, Lion U, Kloareg B, Potin P (2005) Dissection of two distinct defense-related responses to agar oligosaccharides in Gracilaria chilensis (Rhodophyta) and Gracilaria conferta (Rhodophyta). J Phycol 41:863-873

- Weinberger F, Beltran J, Correa JA, Lion U and others (2007) Spore release in Acrochaetium sp. (Rhodophyta) is bacterially controlled. J Phycol 43:235-241

Wheeler GL, Tait K, Taylor A, Brownlee C, Joint I (2006) Acylhomoserine lactones modulate the settlement rate of zoospores of the marine alga Ulva intestinalis via a novel chemokinetic mechanism. Plant Cell Environ 29:608-618

Whitman WB, Coleman DC, Wiebe WJ (1998) Prokaryotes: the unseen majority. Proc Natl Acad Sci USA 95: 6578-6583

Wiese J, Thiel V, Gärtner A, Schmaljohann R, Imhoff JF (2009a) Kiloniella laminariae gen. nov., sp. nov., a new Alphaproteobacterium from the marine macroalga Laminaria saccharina. Int J Syst Evol Microbiol 59:350-356

Wiese J, Thiel V, Nagel K, Staufenberger T, Imhoff JF (2009b) Diversity of antibiotic active bacteria associated with the brown alga Laminaria saccharina from the Baltic Sea. Mar Biotechnol 11:287-300

- Wikström SA, Pavia H (2004) Chemical settlement inhibition versus post-settlement mortality as an explanation for differential fouling of two congeneric seaweeds. Oecologia 138:223-230 
Wong TY, Preston LA, Schiller NL (2000) Alginate lyase: Review of major sources and enzyme characteristics, structure-function analysis, biological roles, and applications. Annu Rev Microbiol 54:289-340

Woo JH, Kitamura E, Myouga H, Kamei Y (2002) An antifungal protein from the marine bacterium Streptomyces sp. Strain AP77 is specific for Pythium porphyrae, a causative agent of red rot disease in Porphyra spp. Appl Environ Microbiol 68:2666-2675

Wright JT, de Nys R, Steinberg PD (2000) Geographic variation in halogenated furanones from the red alga Delisea pulchra and associated herbivores and epiphytes. Mar Ecol Prog Ser 207:227-241

Wright AD, de Nys R, Angerhofer CK, Pezzuto JM, Gurrath M (2006) Biological activities and 3D QSAR studies of a series of Delisea pulchra (cf. fimbriata) derived natural products. J Nat Prod 69:1180-1187

Wu CY (1990) Cultivation of temperate seaweeds in the Asia Pacific region. In: Technical resource papers regional workshop on the culture and utilization of seaweeds. Vol II. Regional seafarming development and demonstration project RAS/90/002, 27-31 August 1990, Cebu City, Philippines. FAO/UNPP

Xu N, Fan X, Yan X, Li X, Niu R, Tseng CK (2003) Antibacterial bromophenols from the marine red alga Rhodomela confervoides. Phytochemistry 62:1221-1224

Yamasaki T, Miyazaki Y, Kamei Y (1998) Isolation of bacteria that decompose major polysaccharides in the cell wall of the marine red alga Porphyra yezoensis and their application for protoplast production. Can J Microbiol 44:789-794

Yamaura I, Matsumoto T, Funatsu M, Funatsu Y (1990) Purification and some properties of endo-l, 4-/ $\beta$-D-mannanase from Pseudomonas sp. PT-5. Agric Biol Chem 54: 2425-2427

Yan L, Boyd KG, Burgess JG (2002) Surface attachment induced production of antimicrobial compounds by marine epiphytic bacteria using modified roller bottle cultivation. Mar Biotechnol 4:356-366

Yan L, Boyd KG, Adams DR, Burgess JG (2003) Biofilm-specific cross-species induction of antimicrobial compounds in bacilli. Appl Environ Microbiol 69:3719-3727

Yang R, Fang W, Shan Y, Chen H, Sun X, Ye Y (2008) Genetic diversity of epiphytic bacteria in Porphyra yezoensis. Acta Oceanol Sin 30:161-168

Yaphe W (1957) The use of agarase from Pseudomonas atlantica in the identification of agar in marine algae (Rhodophyceae). Can J Microbiol 3:987-993

Yaphe W (1962) Detection of marine alginolytic bacteria. Nature 196:1120-1121

Yaphe W, Baxter B (1955) The enzymic hydrolysis of carrageenan. Appl Microbiol 3:380-383

> Yong JJ, Park SJ, Kim HJ, Rhee SK (2007) Glaciecola agarilytica sp. nov., an agar-digesting marine bacterium from the East Sea, Korea. Int J Syst Evol Microbiol 57:951-953

Yoon J, Matsuo Y, Adachi K, Nozawa M, Matsuda S, Kasai H, Yokota A (2008) Description of Persicirhabdus sediminis gen. nov., sp. nov., Roseibacillus ishigakijimensis gen. nov., sp. nov., Roseibacillus ponti sp. nov., Roseibacillus persicicus sp. nov., Luteolibacter pohnpeiensis gen. nov., sp. nov. and Luteolibacter algae sp. nov., six marine members of the phylum 'Verrucomicrobia', and emended descriptions of the class Verrucomicrobiae, the order Verrucomicrobiales and the family Verrucomicrobiaceae. Int J Syst Evol Microbiol 58:998-1007

> Yoshikawa K, Takadera T, Adachi K, Nishijima M, Sano H (1997) Korormicin, a novel antibiotic specifically active against marine Gram-negative bacteria, produced by a marine bacterium. J Antibiot (Tokyo) 50:949-953

Yoshimura T, Tsuge K, Sumi T, Yoshiki M and others (2006) Isolation of porphyran-degrading marine microorganisms from the surface of red alga, Porphyra yezoensis. Biosci Biotechnol Biochem 70:1026-1028

Yumoto I, Ezura Y, Kimura T (1989a) Distribution of the Alteromonas sp., the causative agent of red-spots on the culture bed of makonbu Laminaria japonica, in the coastal area of Funka Bay. Nippon Suisan Gakkaishi 55:453-462

Yumoto I, Yamaguchi K, Yamada K, Ezura Y, Kimura T (1989b) Relationship between bacterial flora and occurrence of the of the Alteromonas sp., the causative agent of red-spots on the culture bed of makonbu Laminaria japonica, in the coastal area of Funka Bay. Nippon Suisan Gakkaishi 55:1907-1914

> Yurkov VV, Beatty JT (1998) Aerobic anoxygenic phototrophic bacteria. Microbiol Mol Biol Rev 62:695-724

Zheng L, Han X, Chen H, Lin W, Yan X (2005) Marine bacteria associated with marine macroorganisms: the potential antimicrobial resources. Ann Microbiol 55:119-124

Zhou M, Han F, Li J, Zhao X (2008) Isolation and identification of a novel alginate-degrading bacterium, Ochrobactrum sp. Songklanakarin J Sci Technol 30:135-140

Appendix 1. Studies of bacterial communities attached to the surface of different macroalgae over the last 40 yr. CUD = culture dependent methods. Microscopical methods: EPF = epifluorescence microscopy, EM = electron microscopy, SEM = scanning electron microscopy, STE = stereoscopic microscopy, TEM = transmission electron microscopy. Molecular techniques: CLO = cloning, CFISH = cytogenetic fluorescence in situ hybridization, DGGE = denaturing gradient gel electrophoresis, FISH $=$ fluorescence in situ hybridization, IFN = immunofluorescent detection, RQT = real time quantitative PCR, RFLP = restriction fragment length polymorphism, TRFLP = terminal restriction fragment length polymorphism of DNA

\begin{tabular}{|llll|}
\hline Macroalga & Methodology & Location & Source \\
\hline Chlorophyta & & & \\
Chlorophyta spp. & STE & San Juan Island, USA & Bland \& Brock (1973) \\
Caulerpa cupressiodes & DGGE, SEM & Tampa Bay, USA & Delbridge et al. (2004) \\
Caulerpa mexicana & DGGE, SEM & Tampa Bay, USA & Delbridge et al. (2004) \\
Caulerpa prolifera & DGGE, SEM & Tampa Bay, USA & Delbridge et al. (2004) \\
& EM, STE & Tampa Bay, USA & Dawes \& Lohr (1978) \\
\hline
\end{tabular}


Appendix 1 (continued)

\begin{tabular}{|c|c|c|c|}
\hline Macroalga & Methodology & Location & Source \\
\hline Caulerpa racemosa & TRFLP, SEM & Hong Kong & Dobretsov et al. (2006b) \\
\hline Caulerpa sertulariodes & DGGE, SEM & Tampa Bay, USA & Delbridge et al. (2004) \\
\hline Caulerpa taxifolia & RFLP & $\begin{array}{l}\text { Mediterranean, Tahiti, } \\
\text { Philippines, Australia }\end{array}$ & Meusnier et al. (2001) \\
\hline Chaetomorpha brachygona & CUD & Tolo, Hong Kong & Kong \& Chan (1979) \\
\hline Chaetomorpha media & CUD & Anjuna \& Baga, India & Ramaiah \& Chandramohan (1992) \\
\hline Chaetomorpha sp. & CUD & Vellar Estuary, India & $\begin{array}{l}\text { Lakshmanaperumalsamy \& } \\
\quad \text { Purushothaman (1982) }\end{array}$ \\
\hline Chara aspera & FISH & Baltic Sea, Germany & Hempel et al. (2008) \\
\hline Cladophora rupestris & CUD & France & Barbeyron \& Berger (1989) \\
\hline Codium cylindricum & CUD & Tolo, Hong Kong & Kong \& Chan (1979) \\
\hline Codium fragile & CUD & Scotland & Boyd et al. $(1999 a, b)$ \\
\hline Enteromorpha compressa & CUD & Ria de Arosa \& Pontevedra, Spain & Lemos et al. (1985) \\
\hline Enteromorpha intestinalis & CUD & Ria de Arosa \& Pontevedra, Spain & Lemos et al. (1985) \\
\hline Enteromorpha linza & CUD & Japan & Shiba \& Taga (1980) \\
\hline \multirow[t]{2}{*}{ Enteromorpha sp. } & CUD & Vellar Estuary, India & $\begin{array}{l}\text { Lakshmanaperumalsamy \& } \\
\text { Purushothaman (1982) }\end{array}$ \\
\hline & IFN & Auckland, New Zealand & Booth \& Hoppe (1985) \\
\hline Halimeda copiosa & CUD, EPF & Bahamas Islands & Jensen et al. (1996) \\
\hline Halimeda tuna & SEM, EM & Lecce, Italy & Colombo (1978) \\
\hline Monostroma nitidum & CUD & Japan & Shiba \& Taga (1980) \\
\hline Monostroma undulatum & CUD & Puerto Deseado, Argentina & Gallardo et al. (2004) \\
\hline Udotea petiolata & SEM, EM & Sardinia, Italy & Colombo (1978) \\
\hline \multirow[t]{5}{*}{ Ulva australis } & DGGE, CLO & Shark Point, Australia & Longford et al. (2007) \\
\hline & DGGE,CFISH & Shark Point, Australia & Tujula et al. (2010) \\
\hline & DGGE, CLO & Sydney, Australia & Burke et al. (2009), Delbridge et al. (2004) \\
\hline & CUD, EPF & Sydney, Australia & Rao et al. $(2006,2007)$ \\
\hline & CUD & Sydney, Australia & Penesyan et al. (2009) \\
\hline \multirow[t]{2}{*}{ Ulva compressa } & DGGE & Baltic \& North Sea, Germany & Lachnit et al. (2009) \\
\hline & TRFLP & Chañaral, Chile & Moran et al. (2008) \\
\hline Ulva fasciata & CUD & Anjuna \& Baga, India & Ramaiah \& Chandramohan (1992) \\
\hline \multirow{7}{*}{ Ulva lactuca } & CUD & Scotland & Boyd et al. $(1999 a, b)$ \\
\hline & CUD & Tolo, Hong Kong & Kong \& Chan (1979) \\
\hline & CUD & Spain & Lemos et al. (1985) \\
\hline & CUD, TEM & Massachusetts, USA & Waite \& Mitchell (1976) \\
\hline & CUD, TEM & Sydney, Australia & Egan et al. (2000) \\
\hline & RTQ, DGGE & Kattegat, Denmark & Skovhus et al. (2004) \\
\hline & CFISH, DGGE & Shark Point, Australia & Tujula et al. $(2006,2010)$ \\
\hline \multirow[t]{2}{*}{ Ulva pertusa } & CUD, SEM & Jiaozhou, China & Duan et al. (1995) \\
\hline & CUD & Tuandao Bay, China & Wang et al. (2009) \\
\hline \multirow[t]{2}{*}{ Ulva reticulata } & CUD, SEM & Malaysia & Vairappan \& Suzuki (2000) \\
\hline & CUD, SEM & Hong Kong & Dobretsov \& Qian (2002) \\
\hline \multirow[t]{2}{*}{ Ulva rigida } & CUD & Las Salinas Beach, Spain & Bolinches et al. (1988) \\
\hline & CUD & Pleubian, France & Liot et al. (1993) \\
\hline Ulva sp. & CUD & Japan & Shiba \& Taga (1980) \\
\hline \multirow{2}{*}{ Ulva spp. } & RTQ, DGGE & Kattegat, Denmark & Skovhus et al. (2004) \\
\hline & CUD, EPF & Uminokoven, Japan & Uchida \& Murata (2004) \\
\hline Ulvaria fusca & RTQ, DGGE & Kattegat, Denmark & Skovhus et al. (2004) \\
\hline \multicolumn{4}{|c|}{ Heterokontophyta, Phaeophyceae } \\
\hline \multirow[t]{3}{*}{ Ascophyllum nodosum } & CUD & Trondheimsfjord, Norway & Sieburth \& Jensen (1967) \\
\hline & SEM & Massachusetts, USA & Cundell et al. (1977) \\
\hline & SEM & Camp Varnum, RI, USA & Sieburth \& Tootle (1981) \\
\hline Chordaria flagelliphormis & CUD & Sea of Japan, Russia & Beleneva \& Zhukova (2006) \\
\hline Colpomenia sinuosa & CUD & Awaji Island, Japan & Kanagasabhapathy et al. $(2006,2009)$ \\
\hline Cystoseira sp. & CUD & San Sebastian, Spain & Genilloud et al. (1994) \\
\hline Desmarestia viridis & CUD & Sea of Japan, Russia & Beleneva \& Zhukova (2006) \\
\hline Dictyota dichotoma & CUD & Gijon, Spain & Genilloud et al. (1994) \\
\hline \multirow[t]{2}{*}{ Ecklonia cava } & CUD & Awaji Island, Japan & Kanagasabhapathy et al. (2006) \\
\hline & SEM & Kommetjie, South Africa & Koop et al. (1982) \\
\hline
\end{tabular}


Appendix 1 (continued)

\begin{tabular}{|c|c|c|c|}
\hline Macroalga & Methodology & Location & Source \\
\hline Ecklonia maxima & CUD & Oudekraal, South Africa & Mazure \& Field (1980) \\
\hline Ectocarpus siliculosus & CUD & Tolo, Hong Kong & Kong \& Chan (1979) \\
\hline \multirow[t]{2}{*}{ Eisenia bicyclis } & CUD & Japan & Shiba et al. (1979) \\
\hline & CUD, SEM & Japan & Sakami \& Sugiyama (1994) \\
\hline Fucus ceranoides & CUD & Spain & Lemos et al. (1985) \\
\hline \multirow[t]{2}{*}{ Fucus serratus } & CUD & Scotland & Boyd et al. $(1999 a, b)$ \\
\hline & DGGE & Baltic \& North Sea, Germany & Lachnit et al. (2009) \\
\hline Fucus sp. & EPF, CUD & White Sea, Russia & Semenova et al. (2009) \\
\hline \multirow[t]{5}{*}{ Fucus vesiculosus } & SEM & Camp Varnum, RI, USA & Sieburth \& Tootle (1981) \\
\hline & CUD & Gijon, Spain & Genilloud et al. (1994) \\
\hline & CUD & Las Salinas Beach, Spain & Bolinches et al. (1988) \\
\hline & IFN & Baltic Sea, Germany & Booth \& Hoppe (1985) \\
\hline & DGGE & Baltic \& North Sea, Germany & Lachnit et al. (2009) \\
\hline \multirow{2}{*}{ Himanthalia elongata } & CUD & Scotland & Boyd et al. (1999a,b) \\
\hline & CUD & Gijon, Spain & Genilloud et al. (1994) \\
\hline \multirow[t]{3}{*}{ Laminaria digitata } & CUD, SEM & Bay of Brest, France & Corre \& Prieur (1990) \\
\hline & CUD & Scotland & Boyd et al. $(1999 a, b)$ \\
\hline & CUD & Roscoff, France & Salaün et al. (2010) \\
\hline Laminaria hyperborea & DGGE, EPF & Bergen, Norway & Bengtsson et al. (2010) \\
\hline \multirow[t]{5}{*}{ Laminaria japonica } & CUD, SEM & Jiaozhou, China & Duan et al. (1995) \\
\hline & CUD & Primor'e, Russia & Dimitrieva \& Dimitriev (1996) \\
\hline & CUD & Shandong Province, China & Wang et al. (2008) \\
\hline & CUD & Sea of Japan, Russia & Beleneva \& Zhukova (2006) \\
\hline & CUD & Tuandao Bay, China & Wang et al. (2009) \\
\hline Laminaria longicruris & CUD & Nova Scotia, Canada & Laycock (1974) \\
\hline Laminaria pallida & CUD & Oudekraal, South Africa & Mazure \& Field (1980) \\
\hline \multirow{2}{*}{ Laminaria saccharina } & DGGE & Baltic \& North Sea, Germany & Lachnit et al. (2009) \\
\hline & DGGE, CLO & Baltic \& North Sea, Germany & Staufenberger et al. (2008) \\
\hline Lobophora variegata & CUD, EPF & Bahamas Islands & Jensen et al. (1996) \\
\hline Macrocystis integrifolia & SEM & Bamfield Inlet, Canada & Roland (1975) \\
\hline Nereocystis luetkeana & SEM & Bamfield Inlet, Canada & Roland (1975) \\
\hline Padina arborescens & CUD & Awaji Island, Japan & Kanagasabhapathy et al. (2006) \\
\hline Padina tetrastromatica & CUD & Anjuna \& Baga, India & Ramaiah \& Chandramohan (1992) \\
\hline Pelvetia canaliculata & CUD & Spain & Lemos et al. (1985) \\
\hline Petalonia fascia & CUD & Awaji Island, Japan & Kanagasabhapathy et al. (2006) \\
\hline \multirow[t]{2}{*}{ Pilayella littoralis } & IFN & Auckland, New Zealand & Booth \& Hoppe (1985) \\
\hline & IFN & Baltic Sea, Germany & Booth \& Hoppe (1985) \\
\hline Sargassum cinereum & CUD & Anjuna \& Baga, India & Ramaiah \& Chandramohan (1992) \\
\hline Sargassum filicinum & CUD & Awaji Island, Japan & Kanagasabhapathy et al. (2006) \\
\hline Sargassum fusiformis & CUD & Awaji Island, Japan & Kanagasabhapathy et al. (2006) \\
\hline Sargassum hemiphyllum & CUD & Tolo, Hong Kong & Kong \& Chan (1979) \\
\hline Sargassum horneri & CUD & Japan & Shiba \& Taga (1980) \\
\hline Sargassum linearifolium & $\mathrm{CFISH}$ & Shark Point, Australia & Tujula et al. (2006) \\
\hline Sargassum seratifolium & CUD & Awaji Island, Japan & Kanagasabhapathy et al. (2006) \\
\hline Sargassum sp. & CUD & Sao Paulo, Brazil & Menezes et al. (in press) \\
\hline Scytosiphon lomentaria & CUD & Awaji Island, Japan & Kanagasabhapathy et al. (2006) \\
\hline \multirow[t]{3}{*}{ Undaria pinnatifida } & CUD & Awaji Island, Japan & Kanagasabhapathy et al. (2006) \\
\hline & CUD & Wando, Korea & Kim et al. (2008) \\
\hline & CUD & Korea & Lee et al. (2006) \\
\hline \multicolumn{4}{|l|}{ Rhodophyta } \\
\hline Amphiroa anceps & CFISH & Shark Point, Australia & Tujula et al. (2006) \\
\hline Antithamnion plumula & CUD & France & Barbeyron \& Berger (1989) \\
\hline Bonnemaisonia asparagoides & TRFLP, EPF & Skagerrak, Sweden & Nylund et al. (2010) \\
\hline Camphylaephora hyphaeoides & CUD & Sea of Japan, Russia & Beleneva \& Zhukova (2006) \\
\hline Ceramium kondoi & CUD & Awaji Island, Japan & Kanagasabhapathy et al. (2008) \\
\hline Ceramium rubrum & IFN & Baltic Sea, Germany & Booth \& Hoppe (1985) \\
\hline Ceramium virgatum & CUD & Skagerrak, Sweden & Nylund et al. (2008) \\
\hline \multirow{2}{*}{ Chondrus crispus } & SEM & Camp Varnum, RI, USA & Sieburth \& Tootle (1981) \\
\hline & CUD & Gijon \& Vigo, Spain & Genilloud et al. (1994) \\
\hline
\end{tabular}


Appendix 1 (continued)

\begin{tabular}{|c|c|c|c|}
\hline Macroalga & Methodology & Location & Source \\
\hline Chondrus oncellatus & CUD & Awaji Island, Japan & Kanagasabhapathy et al. (2008) \\
\hline \multirow[t]{2}{*}{ Clathromorphum sp. } & STE & Oudekraal, South Africa & Johnson et al. (1971) \\
\hline & SEM, CUD & Oudekraal, South Africa & Johnson et al. (1991) \\
\hline Coralline algae & CUD, DGGE & Shark Bay, Australia & Huggett et al. (2006) \\
\hline \multirow[t]{2}{*}{ Corallina officinalis } & CUD & Scotland & Boyd et al. (1999a,b) \\
\hline & CFISH & Shark Point, Australia & Tujula et al. (2006) \\
\hline Delesseria sanguinea & DGGE & Baltic \& North Sea, Germany & Lachnit et al. (2009) \\
\hline \multirow[t]{4}{*}{ Delisea pulchra } & DGGE, CLO & Sydney, Australia & Burke et al. (2009), Delbridge et al. (2004) \\
\hline & DGGE, CLO & Bare Island, Australia & Longford et al. (2007) \\
\hline & CUD & Bare Island, Australia & Penesyan et al. (2009) \\
\hline & CFISH & Shark Point, Australia & Tujula et al. (2006) \\
\hline Gelidium amansii & CUD & Awaji Island, Japan & Kanagasabhapathy et al. (2008) \\
\hline Gelidium caulacantheum & IFN & Auckland, New Zealand & Booth \& Hoppe (1985) \\
\hline Gelidium pusillum & CUD & Anjuna \& Baga, India & Ramaiah \& Chandramohan (1992) \\
\hline Gelidium sp. & CUD & San Sebastian, Spain & Genilloud et al. (1994) \\
\hline Gracilaria changii & CUD & Morib Beach, Malaysia & Musa \& Wei (2008) \\
\hline Gracilaria conferta & CUD & Israel & Weinberger et al. (1997) \\
\hline Gracilaria corticata & CUD & Anjuna \& Baga, India & Ramaiah \& Chandramohan (1992) \\
\hline Gracilaria textorii & CUD & Tuandao Bay, China & Wang et al. (2009) \\
\hline Gracilaria verrucosa & CUD & Sea of Japan, Russia & Beleneva \& Zhukova (2006) \\
\hline Gracilaria spp. & $\mathrm{EPF}$ & Philippines \& Japan & Largo et al. (1997) \\
\hline Grateloupia filicina & CUD & Awaji Island, Japan & Kanagasabhapathy et al. (2008) \\
\hline Hormosira banksii & IFN & Auckland, New Zealand & Booth \& Hoppe (1985) \\
\hline Hypnea charoides & CUD & Tolo, Hong Kong & Kong \& Chan (1979) \\
\hline Hypnea sp. & CUD & Vellar Estuary, India & $\begin{array}{l}\text { Lakshmanaperumalsamy \& } \\
\quad \text { Purushothaman (1982) }\end{array}$ \\
\hline Hypnea valentiae & CUD & Anjuna \& Baga, India & Ramaiah \& Chandramohan (1992) \\
\hline \multirow[t]{2}{*}{ Kappaphycus alvarezii } & $\mathrm{EPF}$ & Philippines \& Japan & Largo et al. (1997) \\
\hline & INF & Philippines & Largo et al. (1998) \\
\hline Laurencia distichophylla & IFN & Auckland, New Zealand & Booth \& Hoppe (1985) \\
\hline Lithophyllum sp. & CUD, SEM & Bicheno, Tasmania & Lewis et al. (1985) \\
\hline Lomentaria catenata & CUD & Awaji Island, Japan & Kanagasabhapathy et al. (2008) \\
\hline Mesophyllum sp. & CUD, SEM & Bicheno, Tasmania & Lewis et al. (1985) \\
\hline Osmundaria serrata & SEM & South Africa & Barreto \& Meyer (2006) \\
\hline Pachymeniopsis lauceolata & CUD & Awaji Island, Japan & Kanagasabhapathy et al. (2008) \\
\hline \multirow[t]{2}{*}{ Palmaria palmata } & CUD & Scotland & Boyd et al. $(1999 a, b)$ \\
\hline & CUD & Pleubian, France & Liot et al. (1993) \\
\hline Phycodrys rubens & DGGE & Baltic \& North Sea, Germany & Lachnit et al. (2009) \\
\hline Plocamium telfairiae & CUD & Awaji Island, Japan & Kanagasabhapathy et al. (2008) \\
\hline Polysiphonia fucoides & CUD & Skagerrak, Sweden & Nylund et al. (2008) \\
\hline \multirow[t]{2}{*}{ Polysiphonia lanosa } & CUD & Tolo, Hong Kong & Kong \& Chan (1979) \\
\hline & SEM & Camp Varnum, RI, USA & Sieburth \& Tootle (1981) \\
\hline Polysiphonia nigrescens & IFN & Baltic Sea, Germany & Booth \& Hoppe (1985) \\
\hline Polysiphonia urceolata & CUD & Tuandao Bay, China & Wang et al. (2009) \\
\hline Porphyra columbina & CUD & San Jorge Gulf, Argentina & Estevao Belchior et al. (2003) \\
\hline Porphyra haitanensis & CUD, SEM & Jiaozhou, China & Duan et al. (1995) \\
\hline Porphyra leucosticta & CUD & Oono-Chyo, Japan & Tsukidate (1971) \\
\hline \multirow[t]{2}{*}{ Porphyra sp. } & CUD & Japan & Shiba \& Taga (1980) \\
\hline & CFISH & Shark Point, Australia & Tujula et al. (2006) \\
\hline \multirow[t]{3}{*}{ Porphyra yezoensis } & CUD, SEM & Jiaozhou, China & Duan et al. (1995) \\
\hline & CUD & Awaji Island, Japan & Kanagasabhapathy et al. (2008) \\
\hline & CUD, DGGE & China & Yang et al. (2008) \\
\hline Rhodomela confervoides & CUD & Skagerrak, Sweden & Nylund et al. (2008) \\
\hline Schizymenia dubyi & CUD & Awaji Island, Japan & Kanagasabhapathy et al. (2008) \\
\hline \multirow[t]{2}{*}{ Sporolithon sp. } & STE & Oudekraal, South Africa & Johnson et al. (1971) \\
\hline & SEM, CUD & Oudekraal, South Africa & Johnson et al. (1991) \\
\hline
\end{tabular}

